\title{
enorden
}

Nordiska ministerrådet

\section{Nordens natur - trender mot 2010}

Exempel på nordiska bidrag till att nå det internationella 2010-målet för biodiversitet

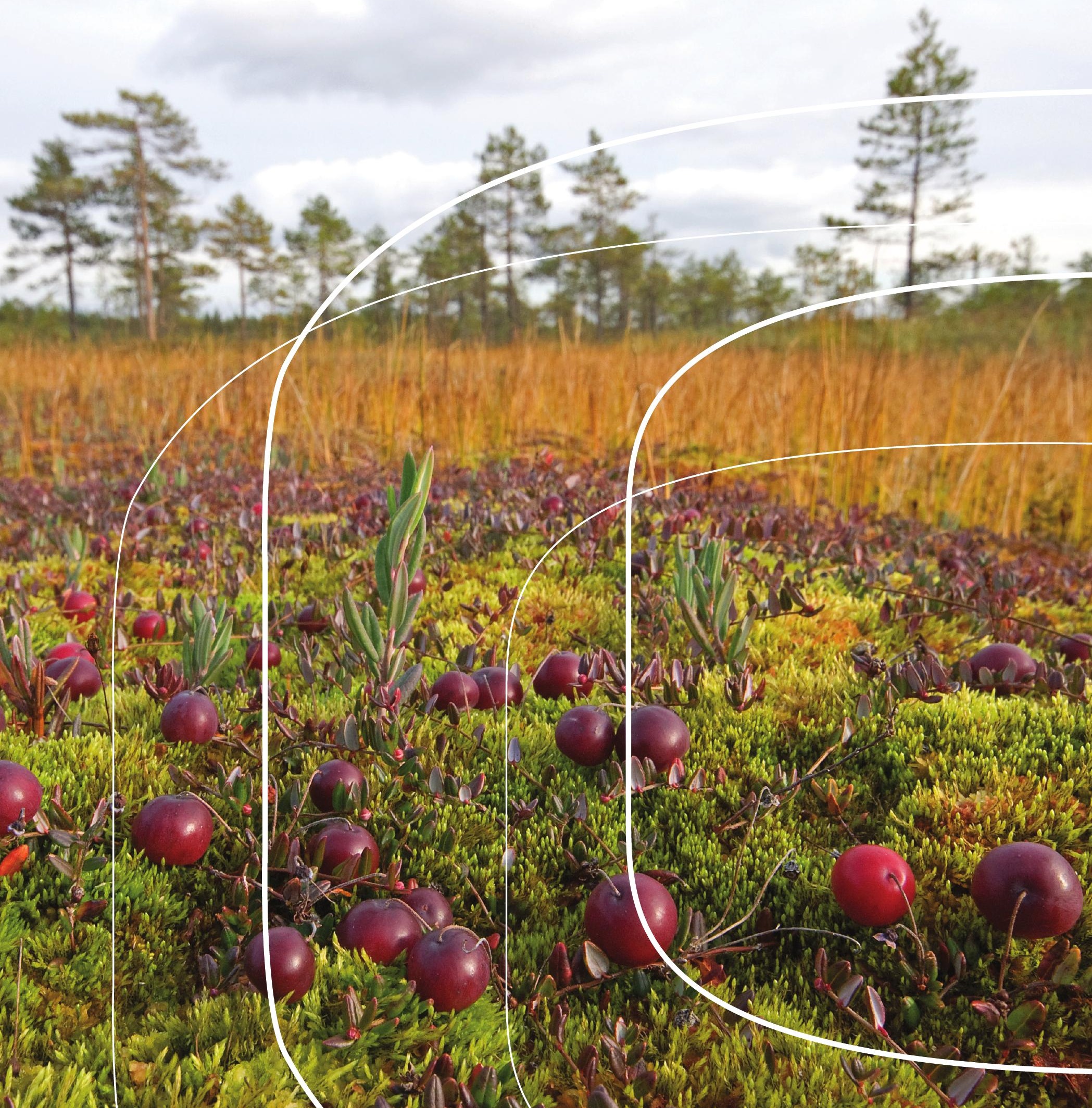



4 nordon 



\section{Nordens natur - trender mot 2010}

Exempel på nordiska bidrag till att nå det internationella 2010-målet för biodiversitet 


\section{Nordens natur - trender mot 2010}

Exempel på nordiska bidrag till att nå det internationella 2010-målet för biodiversitet

TemaNord 2010:507

(C) Nordiska ministerrådet, Köpenhamn 2010

ISBN 978-92-893-1990-4

Omslagsfoto: Markku Mannonen/Kuvaliiteri

Publikationen är tillgänglig som Print on Demand (PoD) och kan beställas på

www.norden.org/order. Fler publikationer finns på www.norden.org/publikationer.

Nordiska ministerrådet

Store Strandstræde 18

DK-1255 Köpenhamn K

Telefon (+45) 33960200

Fax (+45) 33960202

www.norden.org

\section{Nordiska rådet}

Store Strandstræde 18

DK-1255 Köpenhamn K

Telefon (+45) 33960400

Fax (+45) 33111870

\section{Det nordiska samarbetet}

Det nordiska samarbetet är ett av världens mest omfattande regionala samarbeten. Det omfattar Danmark, Finland, Island, Norge och Sverige samt de självstyrande områdena Färöarna, Grönland och Åland.

Det nordiska samarbetet är politiskt, ekonomiskt och kulturellt förankrat och är en viktig partner i europeiskt och internationellt samarbete. Den nordiska gemenskapen arbetar för ett starkt Norden i ett starkt Europa.

Det nordiska samarbetet vill styrka nordiska och regionala intressen och värderingar i en global omvärld. Gemensamma värderingar länderna emellan bidrar till att stärka Nordens ställning som en av världens mest innovativa och konkurrenskraftiga regioner. 


\section{Innehåll}

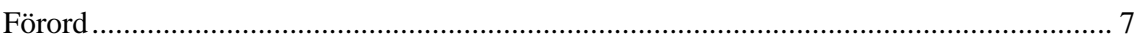

1. Sammanfattning: nordens föränderliga natur............................................................ 11

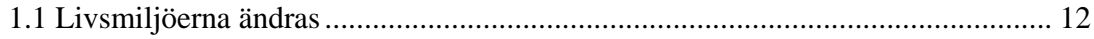

1.2 Arterna i kläm utan människans hjälp ........................................................... 13

1.3 Utsikter för skydd av hotad natur ................................................................... 15

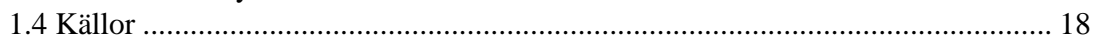

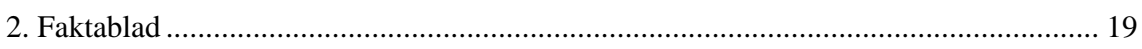

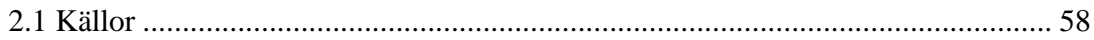

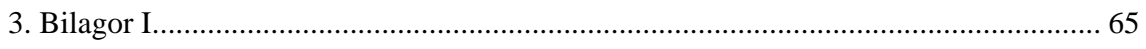

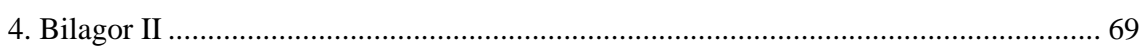

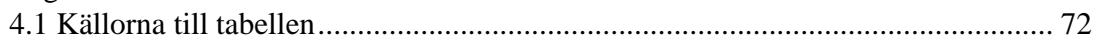





\section{Förord}

År 2010 firas FN:s internationella biodiversitetsår. Med temaåret påminns vi om att biodiversiteten minskar överallt i världen. År 2010 har utsetts till biologiska mångfaldens år också för att det är året som både Europeiska unionen och FN:s konvention om biologisk mångfald har satt som mål för strävan att hejda förlusten av biologisk mångfald.

Målet utarbetades på partsmötet för FN:s konvention om biologisk mångfald år 2002. Samma år, vid toppmötet om hållbar utveckling i Johannesburg, förband sig världens ledare till att minska förlusten av biodiversiteten före år 2010. Målet ingår också i Nordiska ministerrådets miljöhandlingsprogram för åren 2009-2012. Countdown 2010-initiativet, som startats av EU-kommissionen och Världens naturskyddsförbund IUCN, strävar efter att förverkliga målsättningen. Kommunikationsprojektet Nordens natur - trender mot 2010 är en del av Countdown 2010initiativet.

Biologisk mångfald, dvs. biodiversitet, är ett begrepp som innefattar allt liv på jorden. Biodiversiteten delas in i fyra nivåer: genetisk diversitet, artdiversitet och ekosystemdiversitet. Landskapsdiversitet kan räknas som en fjärde nivå. Biologisk mångfald är livets villkor och måste skyddas och bevaras.

Biodiversiteten minskar i snabb takt på hela jorden - också i Norden. I det nordiska miljösamarbetet, som styrs av Nordiska ministerrådets miljöhandlingsprogram, är hejdandet av förlusten av biologisk mångfald före år 2010 ett centralt mål. Nordiska ministerrådet finansierar projekt som siktar på att uppnå målen i handlingsprogrammet samt att förmedla information om dem.

Kunskap ökar förståelsen och respekten för vår oersättliga natur. Kommunikationsprojektet Nordens natur - trender mot 2010, som finansierats av Nordiska ministerrådets arbetsgrupp för terrestra ekosystem TEG, har under åren 2007-2009 producerat material om den biologiska mångfalden i Norden samt dess tillstånd, utvecklingstrender och hot. Med faktabladen har projektgruppen inte strävat efter att ge en helhetsbild av Nordens biodiversitet, utan presenterar enskilda succéer inom biodiversitetsskyddet, men också fall där den negativa trenden inte har kunnat vändas. De största hoten mot biodiversiteten samt deras effekter har behandlats omfattande.

Under projektets gång förmedlade projektet och projektmedlemmarna information om biologiska mångfalden i Norden på flera olika sätt, både nationellt och internationellt. De elektroniska faktabladen har publicerats på projektets hemsidor på internet på alla nordiska språk samt på engelska, vilket möjliggör en effektiv spridning och ett mångsidigt utnyttjande av 
dem till exempel i undervisning. Projektgruppen valde elektronisk informationsförmedling som främsta metod för informationsförmedlingen, eftersom det är lätt och effektivt att sprida information till en bred publik på internet och med e-post. Faktabladen är kompakta informationspaket om utvalda teman, och det är lätt för läsarna att hitta ytterligare information på andra webbplatser som är länkade från projektets hemsida. Faktabladen går att både läsa och skriva ut på internet, och de har gjorts fritt tillgängliga an efter att de publicerats. Hemsidorna och faktabladen kommer att finnas kvar åtminstone under hela biodiversitetsåret 2010.

Ett nyhetsbrev om publiceringen av nya faktablad skickades ut åt en vid målgrupp i alla nordiska länder. Information om projektet samt faktabladen och hemsidorna spreds dessutom med e-post, postkort och tidningsannonser. Pressmeddelanden och tidningsartiklar skrevs om ämnen som behandlades i faktabladen. Flera organisationer och aktörer har länkat projektsidorna från sina egna webbplatser. Projektet och den biodiversitetsinformation som det förmedlade presenterades också i samband med flera olika nationella och internationella seminarier och andra evenemang i Norden och Europa.

Inför det internationella biodiversitetsåret 2010 publicerade projektet en väggkalender med nordiska naturbilder, som påminner om den biologiska mångfaldens betydelse under hela året 2010.

I denna publikation finns alla projektets faktablad i samma format som på internet, där de går att läsa och skriva ut. Publikationen är tryckt på danska och engelska. I elektroniskt format kan den läsas och skrivas ut på Nordiska ministerrådets webbplats samt på projektets hemsida.

Förlusten av biologisk mångfald kunde inte hejdas på väg mot 2010, men målet fick publicitet, och ökade medvetenheten om vikten av hållbart bruk och skydd av den biologiska mångfalden. Konkreta projekt startades och genomfördes på olika håll i Norden, och nya internationella mål kommer att fastställas under år 2010.

Faktabladen som producerast av Nordens natur - trender mot 2010 projektet, webbsidorna och den här publikationen har varit en del av det nordiska bidraget till att nå 2010-målet, genom att öka medvetenheten om den biologiska mångfaldens betydelse.

Följande personer och organisationer har varit med i projektgruppen:

- Marja Pylvänäinen, Finlands miljöcentral SYKE, projektledare

- Sonja Forss, Finlands miljöcentral SYKE, projektassistent

- Tine Nielsen Skafte och Kasper Gade, By- og Landskabsstyrelsen, Danmark

- Sissel Rübberdt och Lars Ekker, Direktoratet for naturforvaltning, Norge

- Mark Marissink, Anna Lind och Anna Ellström, Naturvårdsverket, Sverige 
- Trausti Baldursson, Karl Karlsson och Hildur Vésteinsdóttir, Umhverfisstofnun, Island

- Anna Maria Fosaa, Beinta Johannesen och Herborg Nyholm Debess, Føroya Náttúrugripasavn, Färöarna

- Inge Thaulow och Peter Nielsen, Grønlands Selvstyre, Grönland

Projektgruppen tackar alla som har bidragit till faktabladen genom att ställa sin expertis, sitt material eller sina fotografier till vårt förfogande, samt spridit information om faktabladen. Ett särskilt tack riktas till Hans Skotte Møller vid By- og Landskabsstyrelsen i Danmark, som bidrog med otaliga konstruktiva tankar under projektets gång och särskilt i början. Projektgruppen hoppas att biodiversitetens egenvärde och betydelse uppmärksammas också efter det internationella biodiversitetsåret 2010.

I Helsingfors, Köpenhamn, Trondheim, Stockholm, Reykjavik och Torshamn, 28. januari 2010,

Marja Pylvänäinen, projektledare 
Projektets hemsidor och webbplatser för organisationerna som deltagit $i$ projektet:

- Finlands miljöcentral SYKE [www.miljo.fi] hemsida: [www.miljo.fi/nordensnatur]

- By- og Landskabsstyrelsen, Danmark [www.blst.dk] Hemsida: [www.blst.dk/Biodiversitet/Nordensnatur]

- Direktoratet for naturforvaltning, Norge [www.dirnat.no] hemsida: [http://www.dirnat.no/naturmangfold/internasjonalt/norden/ nordiske trender 2010/]

- Umhverfisstofnun, Island [www.ust.is] hemsida: [www.ust.is/Natturuvernd/liffraedilegfjolbreytni/ natturanordursins]

- Føroya Náttúrugripasavn, Färöarna [www.ngs.fo] hemsida: [www.ngs.fo/Default.aspx?ID=9442]

- Grønlands selvstyre [www.nanoq.gl]

- Naturvårdsverket, Sverige [www.naturvardsverket.se]

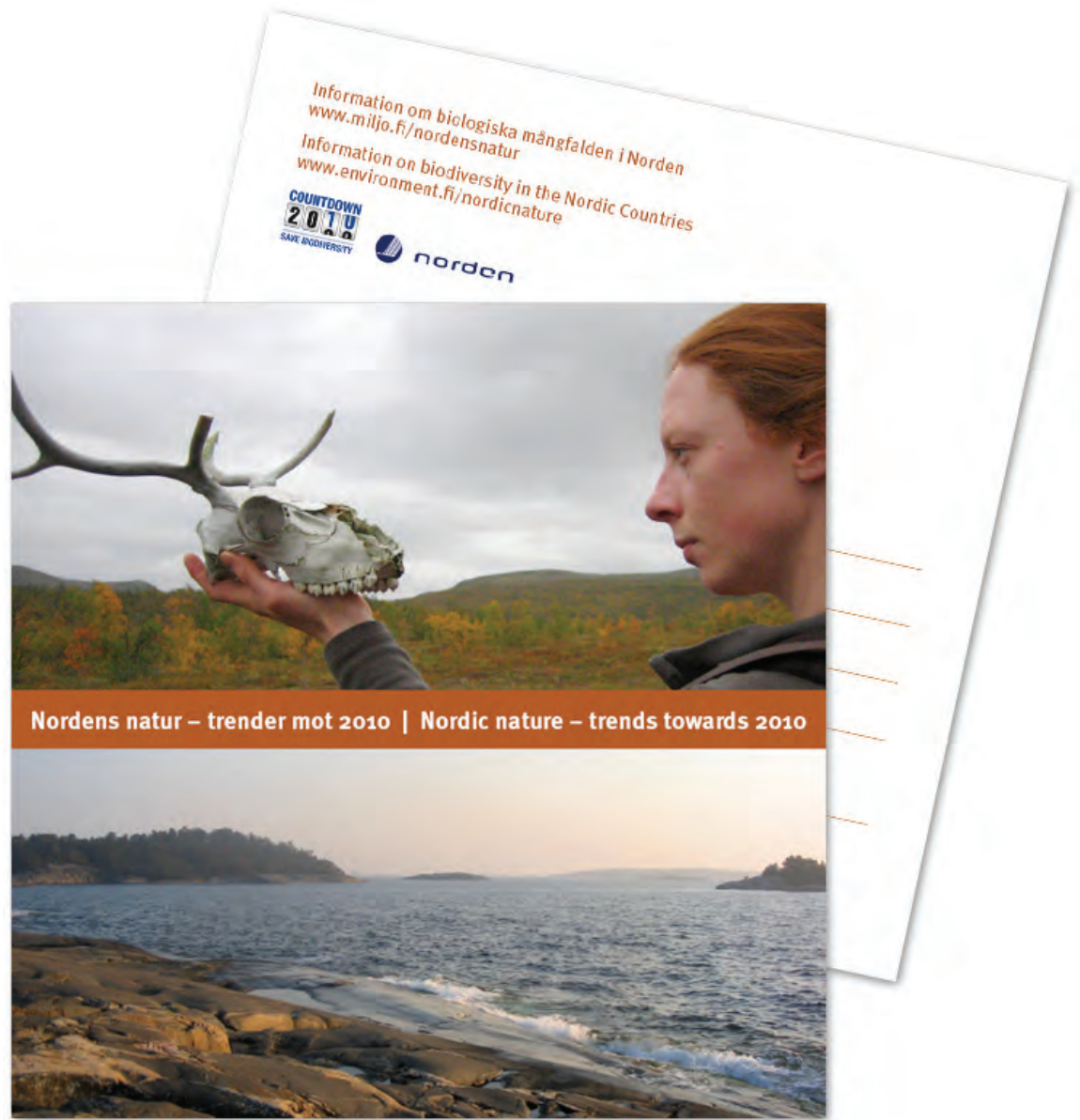

Postkort användes till att sprida information om projektet och faktabladen, som beskriver tillståndet och utvecklingen av biologiska mångfalden i Norden. Bilder: Sonja Forss (övre bilden) och Satu Turtiainen (nedre bilden). 


\section{Sammanfattning: Nordens föränderliga natur}

Människans spår syns överallt i Norden. Spårets intensitet har varierat med tiden, och naturen har behandlats olika på olika håll i Norden. Områdenas fysiska egenskaper, så som klimat, topografi och jordmånens bördighet, men också markanvändningstraditionen och områdets historia har påverkat hur kraftigt naturen och naturresurserna har utnyttjats. Ställvis har den ursprungliga naturen fått ge vika helt och hållet, medan spåret ställvis bara har varit en skråma som har läkt av sig själv.

Människan i Norden har i alla tider förändrat naturen genom att odla jorden, bruka skogen och bygga bostadsområden och infrastruktur. Förändringar som förorsakas av markanvändningen, såsom intensivt jordoch skogsbruk, byggande, dikning, dränering, utfyllnad, deponering och utvinning samt igenväxning och å andra sidan överbete och därav följande slitage och erosion gör livsmiljöer odugliga för arterna. Denna fysiska påverkan förändrar livsmiljöerna och därmed arternas livsvillkor. I vissa fall kan påverkan vara positiv för den biologiska mångfalden, exempelvis måttligt bete, som håller kulturbiotoper öppna så att deras biodiversitet bevaras.

Överdrivet utnyttjande av naturen och naturresurserna försämrar eller förändrar livsmiljöer så att de inte längre är lämpliga för arterna. I extrema fall kan livsmiljöer till och med försvinna helt. Arterna hamnar i trångmål, då deras livsmiljöer krymper och de resterande livsmiljöernas kvalitet sjunker. Hoten mot biologiska mångfalden stärks av klimatförändringen och konkurrens orsakad av främmande arter. Konkurrensen mellan arterna om de minskande livsmiljöerna ökar. Främmande arter som kommit till Norden kan bli invasiva och konkurrera om resurser med våra naturliga arter eller till och med tränga undan dem från sina egna livsmiljöer.

Fångst, jakt, insamling och fiske påverkar artbestånden direkt. Vissa arters bestånd påverkas också direkt av störning och förföljelse, samt dödsfall på grund av trafik, kraftledningar och vindkraftverk. På Grönland är den största utmaningen i biodiversitetsskyddet att övergå till ett allt mer hållbart utnyttjande av naturresurserna. Många arters bestånd har länge utnyttjats alltför kraftigt. Klimatförändringen är också redan ett betydligt hot för Grönlands natur och dess arter.

Som en följd av klimatförändringen, som beror på snabb ekonomisk tillväxt och utveckling, kommer livsmiljöerna att förändras och förflyttas och vissa livsmiljöer kommer att försvinna helt. Då livsmiljöer försvinner, försvinner också deras arter. Detta gäller i synnerhet arktiska och 
alpina arter, vars livsmiljöer är mest hotade. Klimatförändringen förstärker dessutom andra hot mot biodiversiteten. Indirekta verkningar orsakas också av utsläpp på grund av mänsklig aktivitet, samt därav följande eutrofiering, försurning och förorening.

Den mångformiga naturen har fått vika undan för ändringar i markanvändningen som krävs för utvecklingen. I Norden finns ändå fortfarande natur i nästintill orört tillstånd, som är värd att bevara, trots att den ekonomiska verksamheten och dess intensifiering samt ökningen av produktion och konsumtion redan sträcker sig till de mest avlägsna trakter.

\subsection{Livsmiljöerna ändras}

Biologiska mångfalden har utan tvekan minskat också i Norden, men det finns också positiva exempel. Förstörda habitat har restaurerats och arter har återvänt till sina tidigare boplatser.

I takt med att befolkningen har ökat har bebyggda områden brett ut sig allt mera medan de naturliga, artrika miljöerna har minskat i hela Norden. Fragmenteringen av naturen och landskapet fortsätter. Nya vägar och annan bebyggelse splittrar de enhetliga naturområden som ännu finns kvar. De allvarligaste, mest omfattande och synliga ändringarna i markanvändningen har orsakats av att lågproduktiva naturområden, såsom myrar och våtmarker har tagits i bruk för jord- och skogsbruk samt torvproduktion. Känsliga vildmarksarter lider då störningen ökar i och med naturturismen med tillhörande terrängtrafik.

Jordbruket har effektiverats, och å andra sidan upphört på mindre produktiva områden, vilket speciellt de känsliga kulturbiotoperna, som har formats av det traditionella jordbruket, har fått lida av. De har ersatts av stora, enformiga, konstgödslade, maskinellt skötta och täckdikade öppna åkerytor. Småskaligheten med mångformiga dikes- och åkerrenar och trädgrupper har försvunnit ur jordbrukslandskapet.

Hedar, ängar, betesmarker och andra artrika kulturbiotoper är de allra mest hotade naturtyperna i Danmark, Sverige, Norge och Finland. De hotas av igenväxning och kräver regelbunden skötsel i form av slåtter eller bete för att hållas öppna. Igenväxningen förstärks av kvävenedfall. Ett flertal växt- och insektarter är beroende av kulturbiotoperna och har blivit utrotningshotade då deras livsmiljö försvinner. Behovet av kulturbiotopsskydd har lyckligtvis uppmärksammats och skötsel har påbörjats för att återställa kulturbiotoper.

Skogsarealen och skogsbeståndet har ökat i Finland, men det har skett främst genom dikning och beskogning av myrar, vilket har utarmat myrnaturen. Dessa skogar är enformiga och kan inte ersätta naturskogar. Skogsbruksmetoderna har blivit mjukare och samarbetet med naturskyddet har förbättrats. I samband med skogsarbeten beaktas numera den biologiska mångfalden och t.ex. död ved, som är livsviktigt för många hota- 
de skogsarter, lämnas kvar i skogen vid hyggen. Gamla, över 140-åriga skogar har ökat i Sverige och Norge, medan de fortfarande minskar i Finland. På Island och i Danmark har skogsytan ökat, vilket kan ha positiv inverkan för biodiversiteten.

Myrarealen har fortsatt att minska, trots att nydikning och dränering av våtmarker i stort sett har upphört. Myrområden som dikats för skogsbruket iståndsättningsdikas fortfarande. Myrar restaureras också, men ytorna är ännu mycket små.

Förorening och försurning av vattendragen har minskat under de senaste åren, då utsläppen har minskat. I Norge och Sverige har försurade älvar återhämtat sig tack vare kalkning, och laxen (Salmo salar) har återvänt till älvar där den försvunnit på grund av försurning. Den ökande fartygstrafiken och oljeolyckor är fortfarande stora hot speciellt i Östersjön. Eutrofieringen fortgår ännu, men sjöar har också restaurerats med goda resultat. Östersjön mår fortfarande dåligt, och dess sandstränder hotar att växa igen på grund av eutrofiering. Vresrosen (Rosa rugosa) täcker redan nu stora områden av tidigare öppna strand- och dynområden. De danska kustängarna och dynområdena har minskat betydligt, och byggandet på stränderna fortsätter.

Stigande temperatur på grund av klimatförändringen kan komma att forma Nordens natur kraftigt och hota den biologiska mångfalden i vår natur. Följderna är svåra att förutspå, men vissa förändringar som beror på temperaturhöjningen kan redan iakttas. Palsorna smälter, och om nya inte bildas går palsmyrarna förlorade som naturtyp. Inlandsisarna drar sig tillbaka och havsisen, som är livsviktig för isbjörnen (Ursus maritimus), minskar. Vår nordliga fjällnatur ändras då skogsgränsen förflyttas norrut och högre upp i fjällen, och fjällarterna mister sina livsmiljöer. Den känsliga fjällnaturen slits numera också av kraftigt bete.

I Norden grundas naturskyddsområden i rask takt, och arean av skyddade land- och vattenområden ökar. Numera ges stor betydelse speciellt åt att förbättra skyddsområdenas representativitet, och målet är att minst $10 \%$ av alla habitattyper skall skyddas i alla länder. Konflikterna mellan naturskyddet och näringarna fortsätter. Norden borde ta internationellt ansvar för naturtyper som enbart eller huvudsakligen förekommer i Norden, och garantera deras fortbestånd.

\subsection{Arterna i kläm utan människans hjälp}

Hoten, som beskrivs ovan, leder till att allt fler arter blir utrotningshotade. De största hoten är förknippade med ändringar i markanvändningen på grund av ekonomisk verksamhet, dvs. orsakas av människans verksamhet. För en del arter har de akuta hoten kunnat avhjälpas. Det skulle behövas flera succéer såsom skyddet av havsörnen (Haliaeetus albicilla) och saimenvikaren (Phoca hispida saimensis) i Norden. Trots lyckade 
åtgärder har nya hot uppkommit istället för de gamla. Havsörnen, liksom andra rovfåglar, hotas numera också av vindkraftverk, elledningar och stolpar och saimenvikarens förökning försvåras av svaga isar på grund av varmare vintrar och av nätfiske. Klimatförändringen behandlades inte ännu som ett hot i de tidigare nordiska rödlistorna. Nu har det kunnat konstateras att uppvärmningen av klimatet är ett växande hot mot den biologiska mångfalden.

Gråsälens (Halichoerus grypus) och östersjövikarens (Phoca hispida baltica) bestånd har ökat i Östersjön, men de allt varmare vintrarna utgör ett hot mot deras förökning, eftersom de föder på isen i bon av snö. Under dåliga isvintrar kan boen rasa före ungarna kan ta sig ut ur dem, vilket är speciellt oroväckande för den utrotningshotade saimenvikarens del. Ökande sälbestånd leder till konflikter med fiskare, eftersom sälarna äter ur fiskarnas nät.

Trots att fiskeredskapen utvecklas och fångstkvoter har införts hotas flera fiskbestånd fortfarande av överfiske. Nordostatlantens torskbestånd (Gadus morhua) har överfiskats och torskarna har också lidit av näringsbrist på grund av dess bytesarters, sillens (Clupea harengus harengus) och loddans (Mallotus villosus), populationsväxlingar. Det nordostatlantiska sillbeståndet kollapsade i början av 1970-talet. Allt för få könsmogna fiskar lämnades kvar i havet och beståndet fiskades i praktiken ut. Med hjälp av internationella åtgärder kunde lekbeståndet ändå återställas. Också östersjötorsken och strömmingen (Clupea harengus membras) behöver internationell förvaltning.

Fåglarna i odlingslandskapet har minskat betydligt, liksom myrfåglarna. Fjällbjörkskogarnas bergfink (Fringilla montifringilla) har gått tillbaka kraftigt speciellt i Sverige. Också vanliga skogsfåglar, såsom tjädern (Tetrao urogallus) har minskat. I städerna har däremot de vitkindade gässen (Branta leucopsis) ökat, och i havsområdena storskarven (Phalacrocorax carbo). Då klimatet blir varmare flyttas europeiska häckfåglars utbredningsområden flera hundra kilometer mot nordost. För flyttfåglar är det lättare att anpassa sig till ett förändrat klimat än för många andra djurarter, eftersom de är rörliga och egenvarma. De kan reglera tidpunkten för flytten efter väder och tillväxtperiod, och på så sätt försöka söka sig till de mest gynnsamma förhållandena. Hos vissa arter har vårflytten redan blivit tidigare och höstflytten senare. Arterna kan förflytta sig norrut för att häcka, ända tills Ishavet hindrar dem. I synnerhet arktiska och alpina arter hotas, då deras livsmiljöer försvinner.

Groddjuren lider av sjukdomar och av klimatförändringen som gör deras livsmiljöer olämpliga för dem. Groddjurens livsmiljöer restaureras och konstgjorda dammar byggs för dem då deras naturliga lekdammar minskar, vilket har haft stor betydelse för beståndens nuvarande storlek. I Norden har bland annat lövgrodan (Hyla arborea) kunnat räddas då människan har ingripit. Arten var tidigare utrotningshotad i Danmark, men har nu återhämtat sig och finns inte längre upptagen i den danska rödlis- 
tan. Också andra groddjur, såsom större vattensalamandern (Triturus cristatus) har börjat skyddas.

Nordens stora rovdjur; björnen (Ursus arctos), vargen (Canis lupus), järven (Gulo gulo) och lon (Lynx lynx) kunde tidigare leva sida vid sida med den jagande människan. I takt med att människorna blev fler, blev de i högre grad konkurrenter till rovdjuren om fångstmarker och byte. Samtidigt började rovdjuren också komma till bosättningarna och fånga renar (Rangifer tarandus tarandus), boskap och hundar. Detta lade grunden för rovdjurshatet. Först då rovdjuren så gott som hade utrotats i hela Norden kom rovsdjursskyddet igång, och man började betrakta rovdjuren som en del av Nordens natur. Numera är de stora rovdjuren fridlysta och bestånden vårdas, men regleras också genom jakt. Rovdjursförföljelserna har minskat, men rädslan sitter hårt i människan, och rovdjur accepteras inte i närheten av bosättningen.

Fjällräven (Alopex lagopus) är ett exempel på en art som trots skyddåtgärder och uppföljning inte klarar sig i norra Fennoskandien. Fjällrävens tillbakagång antas indirekt bero på klimatförändringen. Klimatförändringen har möjliggjort rödrävens (Vulpes vulpes) spridning norrut, och den konkurrerar om samma livsmiljöer som fjällräven. Den är en starkare konkurrent än fjällräven och breder ut sig på fjällrävens områden. På Nordatlantens öar har fjällrävsbestånden bevarats, eftersom den konkurrerande rödräven inte förekommer där.

Lantrasernas och -sorternas mångfald har minskat, och många av Nordens ursprungliga husdjursraser och växtsorter har blivit utrotningshotade då jordbruket har intensifierats och globaliserats. Det är ett erkänt problem och det finns numera ett nordiskt genresurscenter för att säkra den genetiska mångfalden i Norden. Till all lycka finns också entusiaster, som gör ett värdefullt arbete för att skydda och bevara våra lantraser och sorter.

Problemet med främmande arter har erkänts och i alla nordiska länder utarbetas strategier och handlingsprogram. Informationsförmedlingen om främmande arter har effektiverats i alla länder och intresset för att bekämpa främmande arter har ökat bland allmänheten. Konflikter uppkommer ändå då det handlar om att bekämpa vackra och söta arter, såsom lupiner (Lupinus polyphyllus) och citykaniner (Oryctolagus cuniculus), som inte hör hemma i Nordens natur.

\subsection{Utsikter för skydd av hotad natur}

Förlusten av biologisk mångfald avstannade inte före år 2010, och arbetet med att skydda den biologiska mångfalden tar inte slut. Före nya mål fastställs är det nödvändigt att överväga vad som skall beaktas då de nya målen utformas. I Norden har det fortsatta arbetet redan påbörjats. Med detta som fokus ordnades i Nordiska ministerrådets regi i oktober 2009 en konferens i Trondheim i Norge. Temat var nuvarande status och fram- 
tidsutsikter för nordisk biodiversitet. Cirka 80 deltagare från alla nordiska länder deltog. På konferensen formulerades rekommendationer, som skall utgöra grunden för praktisk och politisk uppföljning i Norden, samt för nordisk insats i ett globalt sammanhang.

I arbetet med att bevara den biologiska mångfalden behöver vi kunskap om naturen och dess arter, naturtyper, processer och funktioner. Genom forskning och uppföljning får man ny kunskap, och med hjälp av kunskapen kan sårbara arter och naturtyper, som behöver skydd, identifieras. Kunskap om bristfälligt kända artgrupper fås endast genom forskning, och kunskap om ändringar i deras bestånd och livsmiljöer bara genom att följa upp dem och upprätthålla regelbundet uppdaterade databaser. Internationellt samarbete är viktigt redan då uppföljningar planeras för att informationen från olika länder skall vara jämförbar. Databaserna är till nytta i många slags rapporteringar som länderna är förpliktigade att genomföra regelbundet åt bland annat sin regering, biodiversitetskonventionens sekretariat samt EU.

Världens naturskyddsförbund IUCN har utarbetat ett klassificeringssystem som ett verktyg i utvärderingen av arternas hotstatus. Systemet möjliggör jämförelser av arters hotstatus på olika regionala nivåer. Utvärderingar och rödlistor över hotade arter har gjorts i alla nordiska länder enligt IUCN:s kriterier, men endast i Finland har också naturtyperna utvärderats. I Norge pågår arbetet med en utvärdering av naturtyperna. På nordiskt initiativ har en databas om främmande arter, Nobanis, startats på internet. Förutom de nordiska länderna deltar redan 10 andra europeiska länder samt europeiska delen av Ryssland i samarbetet. I Norge har en så kallad svartlista gjorts, som listar invasiva främmande arter.

En gynnsam skyddsnivå kan uppnås om det finns tillräckligt med kunskap om arterna och naturtyperna samt deras hotstatus eller livskraft. Habitatskydd utgör grunden för artskyddet. För skyddsändamål stiftas lagar och förordningar och rekommendationer, skyddsplaner, strategier och handlingsprogram utarbetas. För att skydda enskilda arter kan man utforma planer för vård av bestånden, fastställa fredningstider, plantera in individer från andra områden, etablera avelsprogram och genomföra andra skyddsåtgärder för att bevara arternas livskraft. Ofta är det redan för sent då skydd av livsmiljöer sätts in, och livsmiljöerna har redan blivit olämpliga för arterna eller till och med förstörts helt. Då kan man ta till vård och restaurering.

Ett nytt perspektiv och tankesätt inom naturskyddet är ekosystemansatsen, vars idé är att säkra strukturen och funktionen i hela ekosystem. I ekosystemansatsen är det centralt att vara medveten om hurdana tjänster ekosystemen erbjuder, och att de är sårbara, begränsade och livsviktiga för oss människor. Den biologiska mångfalden har ett värde som är svårt att mäta i pengar, som till exempel pollineringstjänsten, som erbjuds växterna och oss människor av insekter. Så gott som alla fröväxter är beroende av pollinering för att kunna producera frön, frukter och nya skördar. 
Också foderväxterna för djur som producerar kött och mjölk, samt oljeväxter måste pollineras. Numera strävar man allt mera efter att mäta och värdera ekosystemtjänster och ändringar i livsmiljöer ekonomiskt, så att deras värde skall kunna beaktas i all samhällelig verksamhet som eventuellt påverkar dem. Också nyttan av insatser för naturen mäts.

Inga skyddsåtgärder är tillräckliga om hoten mot arterna och deras livsmiljöer är bestående. Den bästa skyddsåtgärden är att minimera eller avlägsna hoten. Det allvarligaste hotet mot den biologiska mångfalden är förändringar i markanvändningen. Det behövs naturkompetens på kommunnivå, och för att biodiversiteten skall kunna beaktas i all markanvändning måste kunskapen göras tillgänglig för dem som planerar markanvändningen. I bekämpningen av hoten som orsakas av klimatförändringen och främmande arter är samarbete mellan olika aktörer nödvändigt. I informationsförmedling och kommunikation har media en central roll, liksom skolorna i naturfostran. Bildningen måste börja på gräsrotsnivå, från barn och lokal nivå, men också föras igenom hela samhället och framför allt riktas till beslutsfattarna.

Ett nytt kapitel kan påbörjas i skyddet av biologiska mångfalden i och med utformningen av nya mål efter år 2010. Det kunde vara bra att undvika förbud och att inte måla upp nya hotbilder, och istället bygga upp ett positivt och konstruktivt tillnärmningssätt för att behandla biologiska mångfalden i olika sammanhang. Det är viktigt att få samhällets alla aktörer och nivåer med i arbetet för att bevara den biologiska mångfalden från skolor och familjer till olika aktörer och beslutsfattare. De viktigaste uppgifterna för regeringen och näringslivet är att garantera tillräckliga resurser till bevarandet av den biologiska mångfalden under temaåret 2010 samt efter det. 


\subsection{Källor}

Boertmann, David. 2007. Grønlands Rødliste 2007. Greenland red list. Grønlands Hjemmestyre, Direktoratet for Miljø og Natur.

Gärdenfors U. (red.). 2005. Rödlistade arter i Sverige 2005 - The 2005 Red List of Swedish Species. ArtDatabanken, SLU, Uppsala.

Hallanaro, Eeva-Liisa \& Pylvänäinen, Marja. 2002. Nature in Northern Europe - Biodiversity in a changing environment. Nord 2001:13, Nordic Council of Ministers, Copenhagen.

Kålås, J.A., Viken, Å. \& Bakken, T. (red.). 2006. Norsk Rødliste 2006 2006 Norwegian Red List. Artsdatabanken, Norge.

Nordens natur - trender mot 2010 -projektets faktablad på internet www.miljo.fi/nordensnatur

Normander Bo et.al. 2009. State of biodiversity in the Nordic Countries. An assessment of progress towards achieving the target of halting biodiversity loss by 2010. TemaNord 2009:509. Nordic Council of Ministers, Copenhagen 2008
Rassi, P., Alanen, A., Kanerva, T. \& Mannerkoski, I. (red.). 2001. Suomen lajien uhanalaisuus 2000 - Rödlistade arter i Finland 2000. Miljöministeriet \& Finlands miljöcentral, Helsingfors. Raunio, A., Schulman, A. \& Kontula, T. (red.). 2008. Suomen luontotyyppien uhanalaisuus - Osa 1. Tulokset ja arvioinnin perusteet - Hotbedömningen av Finlands naturtyper - Del 1: Resultat och hotbedömningens grundar. - Miljön i Finland 8:2008.

Raunio, A., Schulman, A. \& Kontula, T. (red.). 2008. Suomen luontotyyppien uhanalaisuus - Osa 2. Luontotyyppien kuvaukset - Hotbedömningen av Finlands naturtyper. - Del 2: Beskrivningar av naturtyper. - Miljön $i$ Finland 8:2008.

Stoltze, M. \& Pihl, S. (red.). 1998. Rødliste 1997 over planter og dyr i Danmark. The Danish Red List 1997. Miljø- og Energiministeriet, Danmarks Miljøundersøgelser og Skovog Naturstyrelsen. 


\section{Faktablad}

- Countdown 2010

- FN:s konvention om biologisk mångfald - biodiversitetskonventionen

- Ekosystemtjänster - vår framtidsförsäkring

- Fiskarternas växelverkan beaktas i Norden - torsk- och sillbestånden i Nordostatlanten

- Östersjöns torsk- och strömmingsbestånd - uppehåll i predator-byte -förhållandet

- Havsörnens framgångsrika återkomst

- Isbjörnen - på toppen av den arktiska näringskedjan och beroende av havsisen

- Nordens unika lantraser

- Fåglar reagerar på klimatförändringen

- Främmande arter i Norden

- Kan Nordens groddjur räddas?

- Mot hållbart bruk av ren-och fårbetesmarker i Norden

- Framgångsrik restaurering och vård av inlandsvatten i Norden

- Lokal medverkan för att hejda förlusten av biologisk mångfald

- Nordens ängs- och betesmarker hotade

- 100-årsjubileum för europeiska nationalparker

- Hot mot biodiversiteten i Norden

- Sandsträndernas rika liv hotas

- Postkort om kommunernas ansvarsarter 


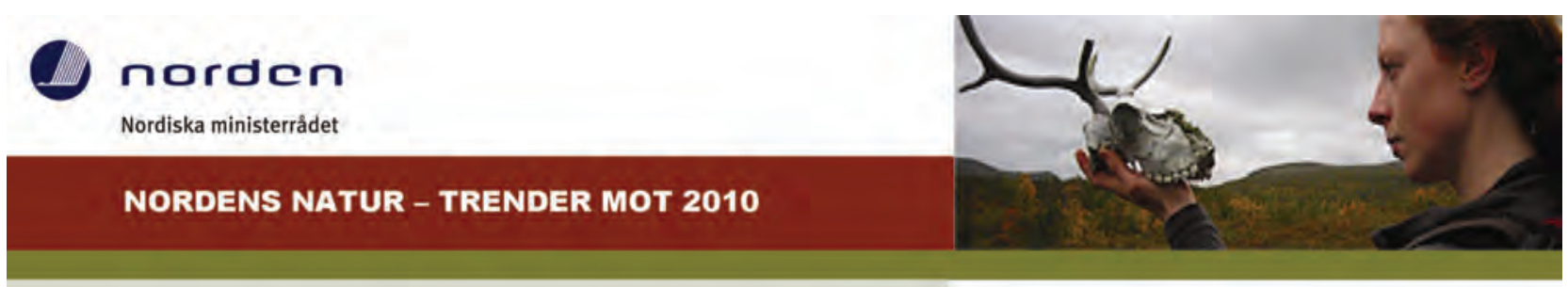

\section{Countdown 2010}

Arter försvinner för tillfället från jorden i mycket snabbare takt än de skulle försvinna naturligt. Minskningen av den biologiska mångfalden anses i huvudsak vara orsakad av människan och följaktligen krävs mänskliga åtgärder för att vända den negativa utvecklingen.

Målet att stoppa minskningen av biodiversitet före år 2010 nämndes för första gången i EU:s strategi för hållbar utveckling år 2001. Följande år formulerades målet att betydligt sakta ner minskningen av biodiversitet före år 2010 pả 6 . partsmötet för $\mathrm{FN}$ :s konvention om biologisk mångfald (CBD). Senare har målet inkluderats i flera andra miljökonventioner och -projekt. Det har också behandlats och godkänts som mål i stora internationella miljökonferenser, som FN-mötet om hållbar utveckling år 2002, FN:s generalförsamling och millenniedeklarationen.

Världens naturskyddsförbund (IUCN) och EU-kommissionen startade år 2004 Countdown 2010-initiativet för att förverkliga målet. Initiativet är numera globalt och ämnar aktivera olika aktörer till arbetet för att bevara den biologiska mångfalden. Countdowndeklarationen kan undertecknas av olika instanser, som t.ex. nationella och lokala administrationer och institut,

medborgarorganisationer och företag. Målens förverkligande följs upp årligen i deltagande länder och organisationer.

Countdown 2010-initiativet definierar sju huvudpunkter i arbetet för att bevara den biologiska mångfalden:

1. Minst $10 \%$ av alla typers ekosystem bör skyddas, så att naturen och naturliga landskap bevaras.

2. Den biologiska mångfalden bör beaktas i jordbruket, bl.a. genom att öka odligsomrảdenas diversitet och minska användningen av bekämpningsmedel och gödsel.

3. Fiskbestånden bör utnyttjas hållbart. För tillfället är $75 \%$ av världens fiskbestånd överfiskade och många arter hotas av utrotning.

4. Den biologiska mångfalden bör beaktas bättre i markanvändning och byggande, som förstör arters habitat.

5. Klimatförändringen ändrar också habitat. Klimatförändringen bör bekämpas, och arternas möjligheter att anpassa sig till ändrade förhållanden eller migration undan förändringen bör säkras.

6. Främmande arter kan i värsta fall tränga undan lokala arter, och deras spridning bör därför hindras.

7. Problem i anknytning till den biologiska măngfalden bör kopplas till all politik, eftersom den är grunden till en hảllbar utveckling.

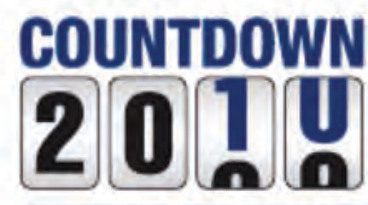

BEVARA NATUREN

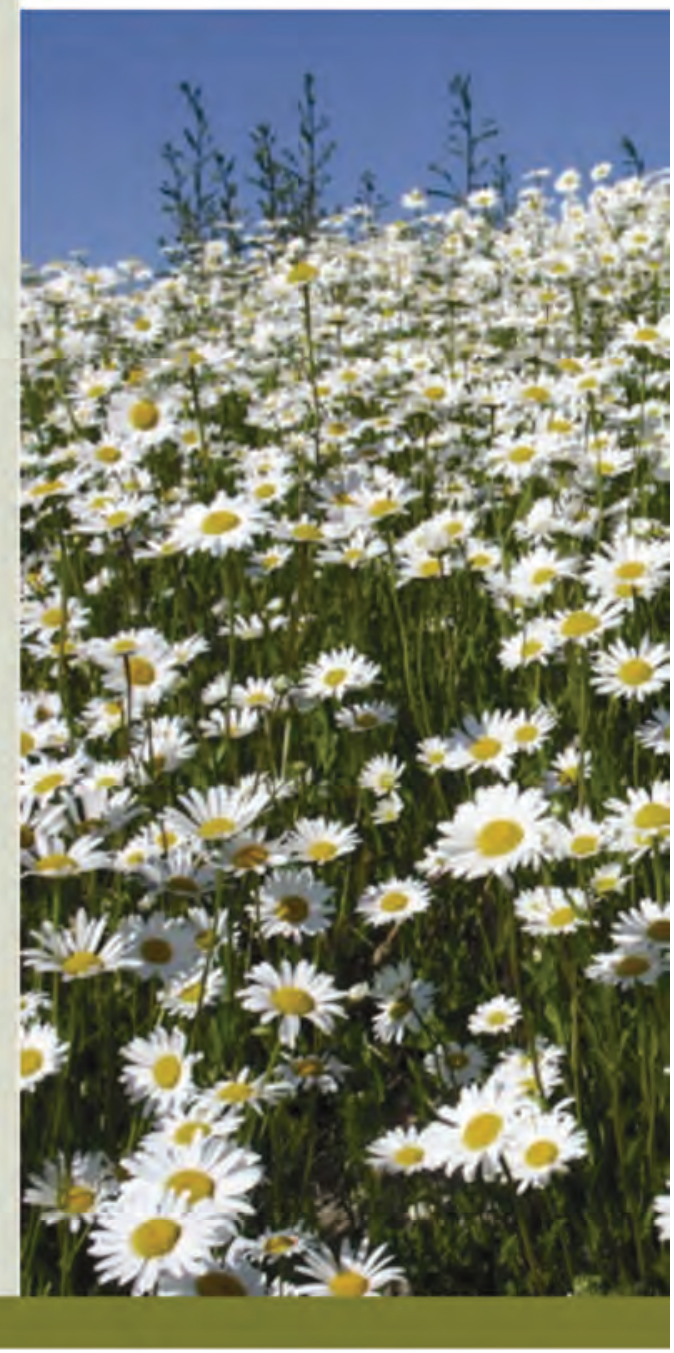


I Europa är ambitionen för att minska utdöendet av arter högre än i resten av världen; målet är inte bara att sakta ner utdöendet, utan att stanna upp det tills år 2010. Europas gemensamma målsättning är att arbeta för förverkligandet av 2010-målet bl.a. genom att verkställa lagar och avtal, som ämnar bevara biodiversiteten. Samtidigt granskas innehållet i EU:s egna politiska program för att de också skall understöda förverkligandet av målet.

Av de nordiska länderna deltar Finland (2006), Sverige (2006), Norge (2007) och Danmark (2007) i Countdown 2010-projektet. I dessa länder har förutom miljöministerierna också t.ex. lokala administrationer, medborgarorganisationer och företag undertecknat deklarationen. Island har inte undertecknat, men 2010-målet ingår ändå bl.a. i landets regeringsprogram.

I Finland har det inom 2010-projektet ordnats en tävling där den bästa gärningen för biodiversiteten belönades. Tävlingen strävar efter att göra lyckade åtgärder för att sakta ner utdöendet av arterna mera kända. År 2006 fick Helsingfors stads byggnadskontor diplomet för landskapsanläggningen på Nordsjö topp. Lokala växtarter har hämtats till den gamla avstjälpningsplatsen och utfyllnadsområdet och därefter har också t.ex. insektarter följd efter, och området har blivit så gott som naturenligt.

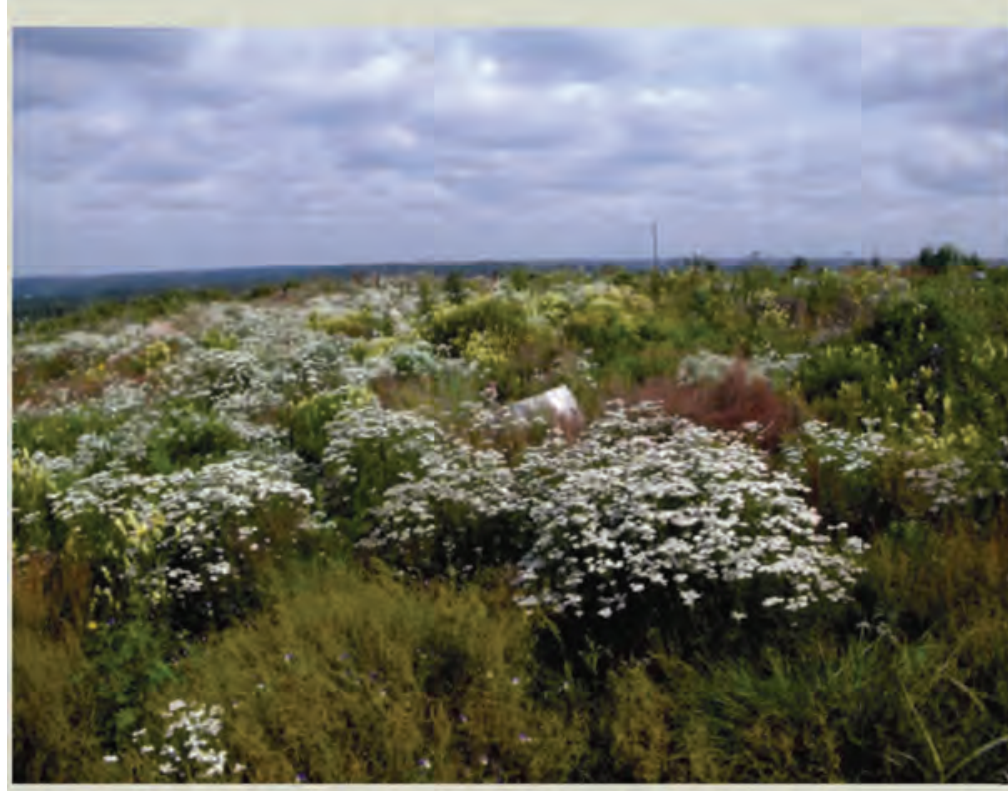

Vy över Nordsjo topp. Bild: Kristiina Pekkonen.

\section{Countown 2010-deklarartionen} har i Norden undertecknats av:

Finland:

Miljöministeriet

Vanda stad

Koskis Gård

Sverige:

Miljöministeriet

Naturhistoriska riksmuséet

Norge:

Miljöministeriet

Trondheims stad

Danmark:

Miljöministeriet

Danska entomologiska sällskapet

Danska ornitologiska föreningen

Danska friluftsrådet

Nephentes, medborgarorganisation Nordeco, medborgarorganisation
Källor: wnw. countdown2010.net, unw.cbd.int, Finlands Countdown 2010deklaration, Norges Countdown 2010deklaration, www. miljo.fi > Internationella frágor > Världsomfattande samarbete > Internationella naturvårdsunionens (IUCN) finska kommitté > Countdown 2010.

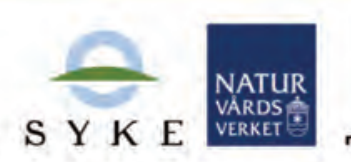

S Y K E

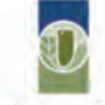

Difiektorate for
noturforvalthing

\section{MILJøMINISTERIET}

By-og Landskabsstyrelsen umhvorvisstovan
Direktoratet for Miljo og Natur

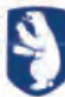




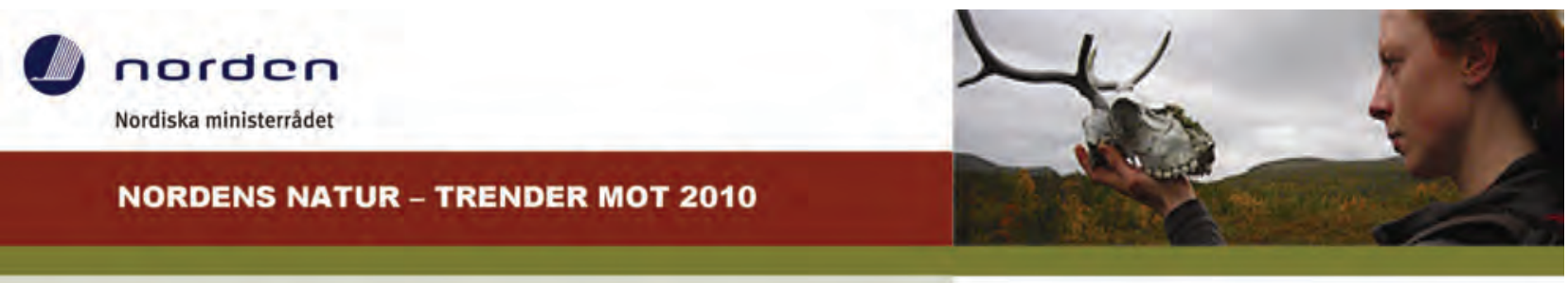

\section{FN:s konvention om biologisk mångfald - biodiversitetskonventionen}

FN:s konvention om biologisk màngfald (Convention on Biological Diversity, CBD) godkändes i Rio de Janeiro àr 1992. Pả det globala toppmötet om hállbar utveckling i Johannesburg 10 ár senare bekräftade statsöverhuvuden i 150 länder att konventionen är det viktigaste verktyget i bevarandet av jordens biologiska mángfald.

För tillfället är 190 länder parter i konventionen, inklusive alla nordiska länderna.

\section{Biologisk mångfald}

Med biologisk mångfald, eller biodiversitet, menas mångfalden bland växter, djur och mikroorganismer samt ekosystem och också den genetiska mångfalden inom arter.

FN:s ekosystemutvärdering (Millennium Ecosystem Assessment) från år 2005 visar att människan under de senaste 50 åren har orsakat större ändringar i ekosystemen än någonsin tidigare under mänsklighetens historia. Arter dör ut 50-100 gånger snabbare än naturligt. De mest betydande orsakerna är habitatförstörelse, invasiva främmande arter, ohållbart utnyttjande av naturresurser klimatförändring och föroreningar. FN:s utvärdering betonar biologiska mångfaldens betydelse för mänsklighetens fortbestånd, välstånd, välbefinnande och trivsel.

\section{0-målet}

På toppmötet om hållbar utveckling i Johannesburg (2002) beslöt biodiversitetskonventionens parter sakta ner den av människan orsakade minskningen av biologisk mångfald tills år 2010. EU har beslutat om ett mer ambitiöst mål, nämligen att stoppa minskingen helt.

\section{Konventionens målsättning och förverkligande}

Enligt biodiversitetskonventionen är människan en del av naturen och berättigad att utnyttja naturresurserna. Effekterna av utnyttjandet på ekosystemen måste ändå samtidigt följas upp. Meningen med konventionen är att skydda den biologiska mångfalden, säkra att naturresurserna används hållbart och trygga en rättvis fördelning av nyttan som fås ur utnyttjandet av den genetiska mångfalden.

Konventionens parter är förpliktade att göra upp en strategi och handlingsplan för skydd och hállbart bruk av den biologiska mangfalden samt att rapportera om verkställandet av konventionen. Konventionen förpliktar parterna till att grunda och upprätthålla naturskyddsområden, skydda utrotningshotade arter och populationer och följa upp den biologiska mångfalden. Naturskyddsområdena skall bilda ett omfattande nätverk där $10 \%$ av ytan av alla naturtyper är skyddade. För en del av naturtyperna är målet inte ännu uppnått.

Rika länder har enligt konventionen ansvar för att hjälpa fattiga länder att verkställa konventionen. Hjälpen kan vara ekonomisk, eller innefatta överföring av teknologi. På så sätt har även de nordiska länderna ett ansvar att hjälpa de länder som de gör biståndssamarbete med.

Biodiversitetskonventionen verkställs genom lagstiftning och annan styrning både nationellt och i samfund som är parter i konventionen, som t.ex. EU.
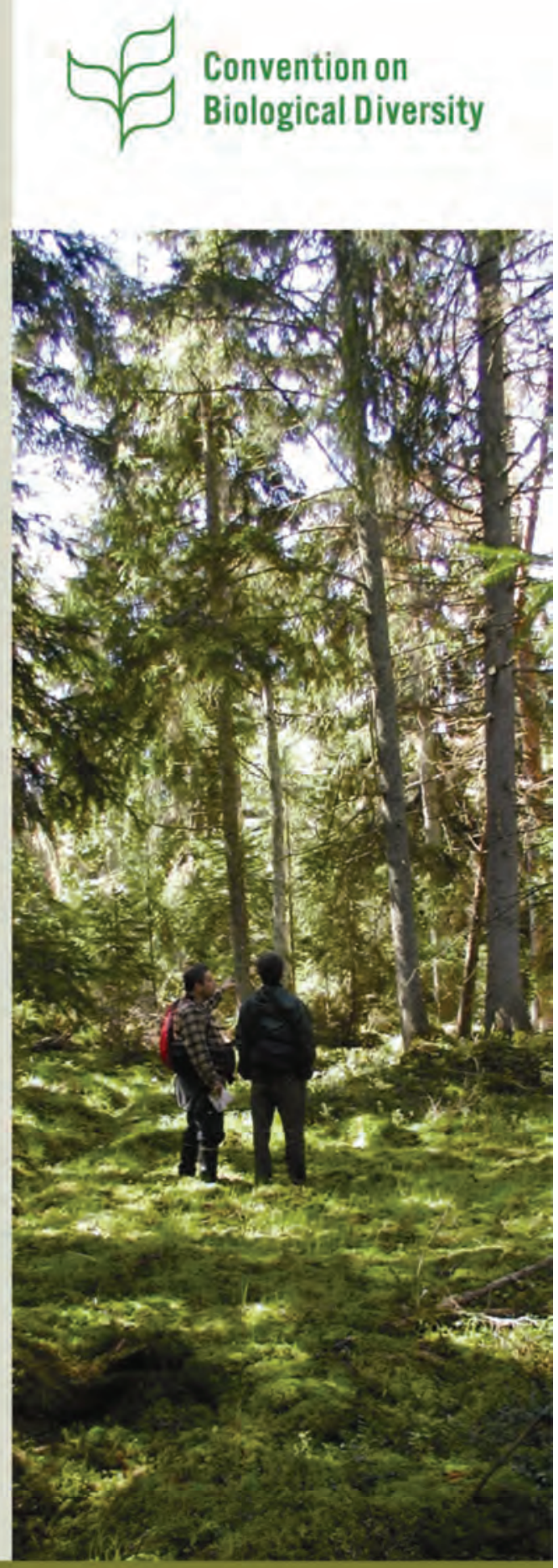


\section{Genresurser och ekosystemtjänster}

Genresurser har en stor ekonomisk betydelse som rảvara för bl.a. bioteknologi, mediciner, kosmetika, odling och förädling. Av världsekonomin baserar sig uppskattningsvis c. $40 \%$ pá biologiska produkter och prosesser, som jordens ekosystem producerar àt mänskligheten som sk. ekosystemtjänster.

Största delen av de genetiska resurserna finns i utvecklingsländerna, men teknologin som behövs för att utnyttja dem kommersiellt finns däremot $i$ industriländema. Konventionen uppmuntrar till att utveckla mekanismer som säkrar att nyttan av utnyttjandet av de genetiska resurserna fördelas rättvist.

\section{Ursprungsbefolkning och traditionell kunskap}

I biodiversitetskonventionen finns ett specifikt arbetsprogram som berör traditionellt levande ursprungsbefolkningar och lokala samhällen. Enligt programmet skall ursprungsbefolkningarnas kunskap om och sätt att utnyttja den biologiska màngfalden hállbart respekteras. Nyttan av utnyttjandet av kunskapen skall ocksả fördelas rättvist.

\section{Informationsspridning och allmän medvetenhet}

Det är viktigt att mânniskor förstâr vikten av att bevara den biologiska mángfalden. Genom att bli parter i biodiversitetskonventionen har medlemsländerna tagit pá sig ansvaret att informera sina medborgare om betydelsen av arterna och habitaten. Varje land skall ha ett informationsförmedlingssystem (Clearing-House Mechanism, CHM) för biodiversitetsinformation. Skydd och hallbart utnyttjande av den biologiska mángfalden skall ocksá ingá i informations-, utbildnings- och uppfostringsprogram.

\section{Konventionens organisation}

De viktigaste organen $\mathrm{i}$ biodiversitetskonventionens organisation ăr partskonferensen (Conference of the Parties, COP), det verkstallande sekretariatet (CBD Secretariat) och underorganet för vetenskaplig, teknisk och teknologisk rádgivning (Subsidiary Body on Scientific, Technical and Technological Advice, SBSTTA). COP samlas till partsmöte med tváa árs mellanrum och beslutar bl.a. om eventuella förändringar av konventionen och dess protokoll, gâr igenom nya forskningsresultat och beslutar om rapportering i samband med konventionen samt utvecklingsbehov.

\section{Biosäkerhetsprotokollet (Cartagenaprotokollet)}

I januari 2000 ingick parterna ett tilläggsavtal, biosäkerhetsprotokollet, eller Cartagenaprotokollet, som behandlar levande genetiskt modifierade organismer (LMO). Avtalet strävar efter ett tillräckligt miljöskydd dả levande genetiskt modifierade organismer flyttas över statsgränser och används internationelt t.ex. I odling och förädling

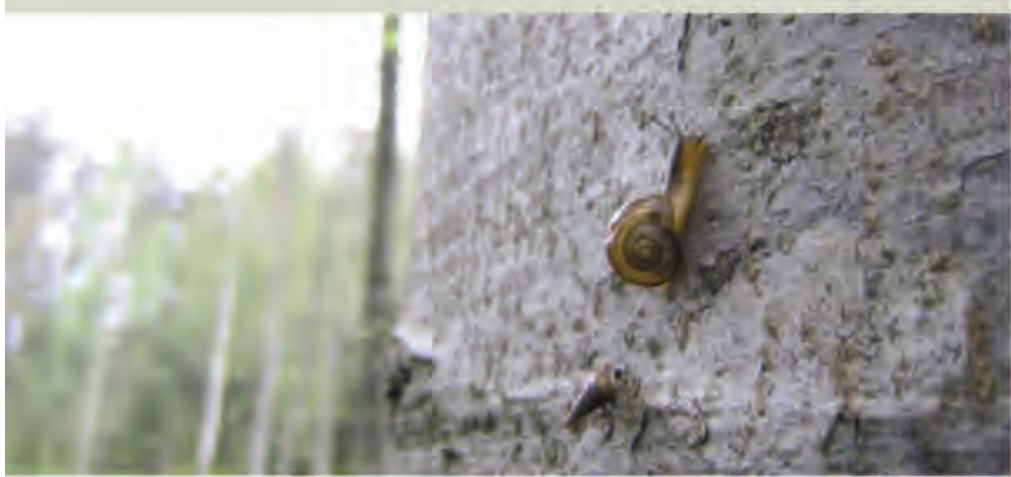

Finlands miljöcentral SYKE - www. miljo.fi/nordensnatur

\section{COP}

Biodiversitetskonventionens nionde partsmöte hälls Bonn 19.-30.5.2008. Huvudteman pá mötet ăr jordbrukslandskapets och skogarnas biodiversitet, invasiva främmande arter, ekosystemansatsen, utveckling av nya styrmedel, globala

växtskyddsstrategin, avancemanget mot att uppná 2010-málet och millenniemálen samt ekonomiska resurser och mekanismer. Förutom dessa huvudteman behandlas ocksả andra ämnen. Speciellt intressanta för de nordiska länderna âr bla:

- skyddsomráden

- biologiska màngfalden och klimatförändring

- biodiversiteten $\mathrm{i}$ inlandsvatten

- biodiversiteten i hav och pá kuster

- biodiversiteten pà öar

- kommunikation, utbildning och allmän medvetenhet

\section{Nordiskt samarbete}

De nordiska länderna har under ledning av Nordiska ministerrádet utvecklat en nordisk genresursstrategi. Mälet med samarbetet är att förstärka arbetet med att bevara den genetiska mangfalden och utnyttja den hallbart $i$ jord- och skogsbruk, fiske och livsmedelsproduktion. Samarbetet främjar förverkligandet av biodiversitetskonventionens mál om de genetiska resursernas tillgänglighet och rabttigheter kring dem.

I Nordeuropa har ett projekt angalende invasiva främmade arter (NOBANIS) ocksá startats, som alla nordiska länderna deltar i. Projektet omfattar bảde havs- och sötvattensekosystem och landekosystem. Det har producerat bl.a. en databas med främmande arter, en förteckning över reglering som gäller främmande arter, en litteraturdatabas och faktablad om flera invasiva främmande arter. Projektet har ocksá goda kontakter till regionala och globala nătverk och andra projekt som anknyter till invasiva främmande arter.

\section{Källor:}

- Convention on Biological Diversity (with annexes). Concluded at Rio de Janeiro on 5 June 1992.

- Nordiska ministerrádet 2006: For a richer future - 13 conventions on the natural and cultural environment. TemaNord 2006:565.

- Ulkoasiainministeriö 2007: Kansainvăliset

ympäristösopimukset ja Suomen kehityspolitiikka 2007. (Finlands utrikesministerium 2007: Internationella miljöfördrag och Finlands bistândspolitik 2007) - Phillips, B. \& Jones, T. 2007: "Mountains to the sea" "Ridge to reef". Implementation Framework for the Convention on Biological Diversity's cross-cutting programmes of work. WWF.

- www.cbd.int

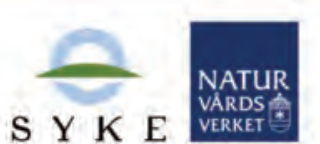

S Y K E

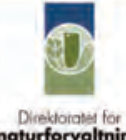

Direkloralit for
naturforvaltning
MILJØMINISTERIET

By-og Landskabsstyrelsen umhvorvisstovan
Grønlands Hjemmestyre

\section{5 .2008}

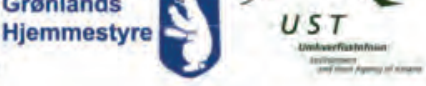




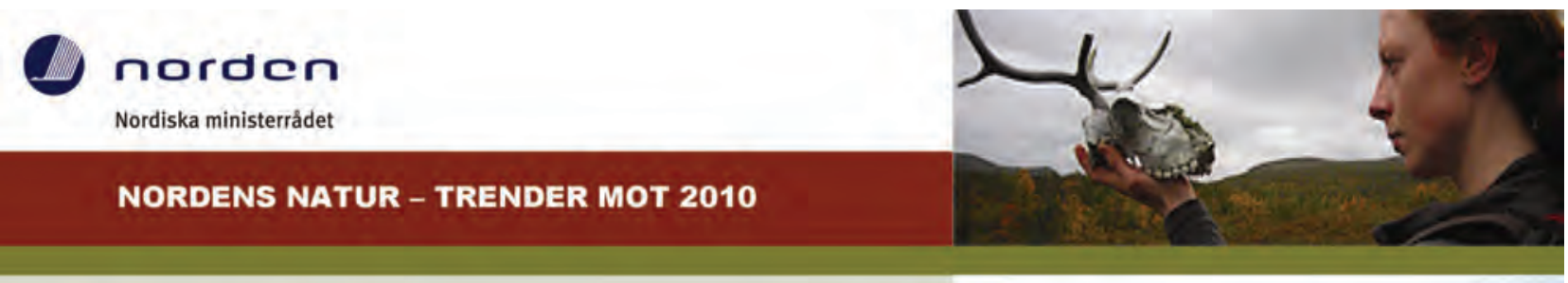

\section{Ekosystemtjänster \\ - vår framtidsförsäkring}

\section{Naturens ekosystemtjänster}

Människan utnyttjar olika tjänster som naturens ekosystem erbjuder, dvs. naturresurser och naturens olika processer. Dessa sả kallade ekosystemtjänster är livsviktiga och oersättliga för oss människor, eftersom vårt uppehälle baserar sig på utnyttjandet av naturresurser som uppstått och formats av naturens processer.

Ekosystemtjänsterna delas in i fyra klasser; produkter, reglerande tjänster, upprätthållande tjänster och kulturtiänster. Med produkter förstås som de allra viktigaste både levande och icke-levande naturresurser som näring, rent dricksvatten och luften vi andas samt bränsle och byggnadsmaterial. Kulturtjänsterna däremot innefattar möjligheten till friluftsliv och rekreation samt naturens estetiska värden. Till de mera svårdefinierade reglerande och upprätthållande tjänsterna hör bland annat pollinering av odlings- och naturväxter, näringsämnenas kretslopp och den översvämningsförebyggande effekten av vătmarker, som är nödvändiga för matproduktionen och bevarandet av den naturliga miljön. Fungerande ekosystem upprättháller näringskretsloppet och därmed jordmånens produktivitet.

Ekosystemtjänsterna är gratis. Utgångspunkten är att det är tillgängliga för oss alla, men i praktiken är de mycket ojämnt fördelade mellan människorna på jorden. De âr också sårbara och inte oändliga och de är beroende av människan för att bevaras. Om vi t.ex. smutsar ner vårt vatten får vi inte längre rent dricksvatten eller om vi utarmar jordmånen blir vi utan fruktbar odlingsmark. Om vi förstör pollinerarnas livsmiljöer förlorar vi en stor del av vår kost som den är idag. Vår utmaning är att synliggöra ekosystemtjänsternas betydelse genom att fråga vilka följderna är om dessa tjänster inte längre fungerar eller om deras funktion försvagas betydligt. Här presenteras som exempel pollineringstjänsten som erbjuds av insekter.

\section{Pollinering - ett exempel på en ekosystemtjänst}

"Om pollinerarna plötsligt dog, skulle människan bara ha några års livstid kvar", sade Einstein då han insåg vilken viktig roll insektpollinerare har i naturens gång. Det ligger mycket i påståendet, trots att en del av våra nuvarande năringsväxter är vindpollinerade. Växter är antingen själv-, vind-, vatten- eller djurpollinerade. I Norden är de valigaste pollinerande djuren insekter, men också fåglar, fladdermöss och andra däggdjur fungerar som pollinerare. Till de effektivastepollinerande insekterna hör bin, getingar, humlor, blomflugor och fjärilar. De pollinerar växter dả de besöker blommorna för att söka näring, och bidrar därmed till frukt- och bärproduktionen.

Människan àr beroende av pollinering, eftersom det är fröväxternas livsvillkor. Nästan alla odlingsväxter kräver pollinering för att producera de frön och frukter som både vi människor och många djur äter. Frön behöver vi också för att fả nya skördar. Också foderväxterna för djur som producerar mjölk och kö̈tt måste pollineras, och likaså oljeväxterna. Vind- och självpollinerade växter klarar sig utan människans hjälp, men de insektpollinerade populationernas fortbestånd är i människans händer. Vi måste se till att de pollinerande insekterna bevaras, för att kunna behålla våra många näringsväxter.

Utan insektpollinering skulle vår kost inte innehålla frukter, bär eller grönsaker - inga av våra viktigaste vitaminkällor och råvaror för traditionella matrătter. Vi skulle sakna trädgårdarnas fruktträd, bärbuskar och -odlingar och köksträdgårdar. Också bärrisen och -buskarna i våra skogar skulle stå tomma. Samtidigt skulle också bärplockning, som har ett stort rekreationsvärde bli omöjligt, eftersom skogsbärsskörden förutom pả väderförhállandena till stor del beror på hur pollineringen lyckas. Honungsbin som hålls $i$ kolonier vid kanterna av fruktodlingar pollinerar odlingamas blommor och producerar honung som människan använder.

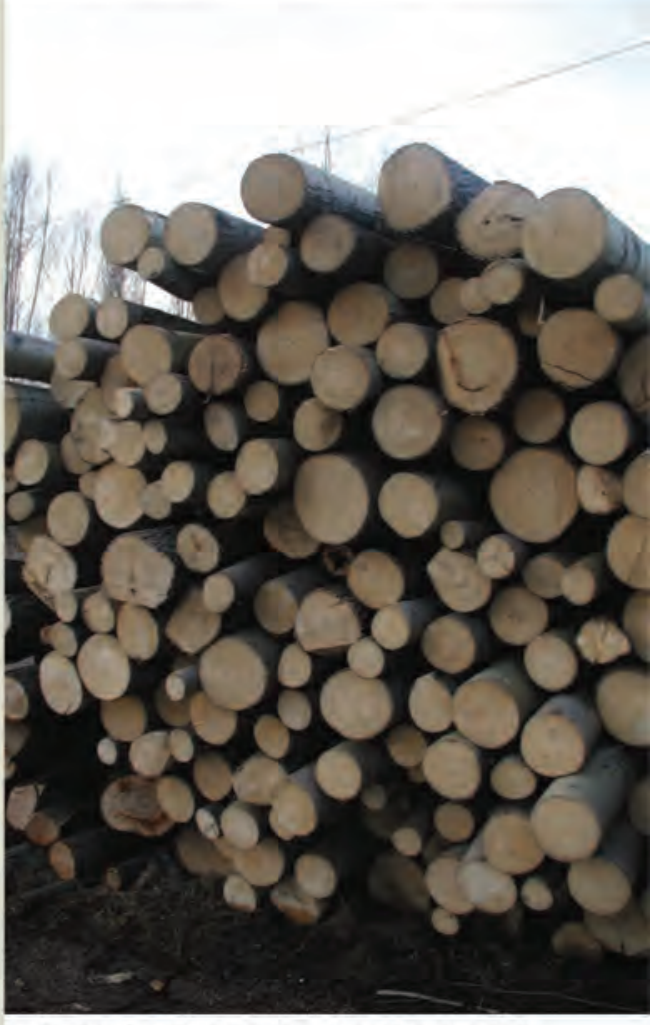

Ur skogar fár man rávaraor för olika produkter samt bränsle. Forutom produkter erbjuder skogarna ocksá kulturtjänster i form av landskap och rekreation. Eftersom skogarna erbjuder mánga olika ekosystemtjänster bör de utnyttjas hällbart

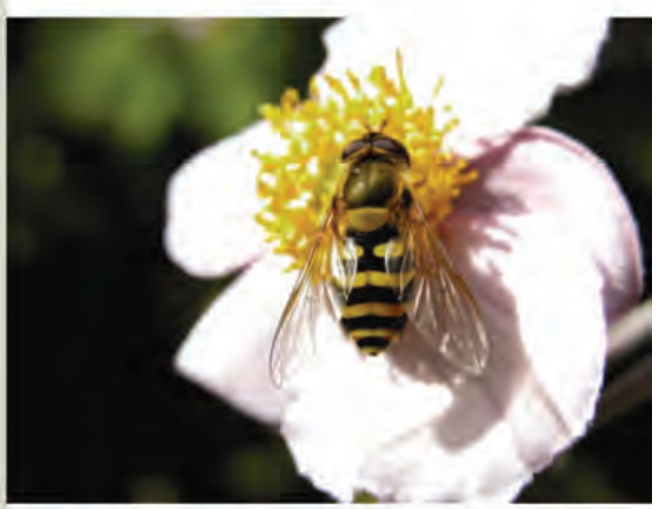

Den gula solblomflugan (Syrphus ribesii) är en allmăn blomfluga och viktig pollinerare. Bild: J. C. Schou. 
Dả insektpollineringens effekt minskar, minskar skördarna, eftersom vinden inte allena räcker till för ett bra pollineringsresultat. Utan insektpollinering skulle vâr kost bestả av vâxter som förökas vegetativt, som tex. potatis, av sjallvpollinerade sädesslag som vete, havre, korn, majs och ris samt vindpollinerade sädesslag som rág. Mjölk- och kôttboskap skulle kunna ăta hö, eftresom grâs är vindpollinerade, men inte beta pà artrika ängar, vars blommor pollineras av insekter. Keliakiker skulle inte ha tillgâng till bovete. Utan pollinering minskar ocksá den genetiska mångfalden hos växter som producerar bär och frukter. Dả blir de med tiden mera mottagliga för växtsjukdomar och skadeinsekter samt för klimatförăndringens effekter, dả deras anpassningsförmága försämras.

\section{Pollineringstjänsten hotad}

Nordens pollinerare hotas av ändringar $i$ ekosystemen som orsakas av markanvändning, som t.ex. ingenväxandet av ängar och habitatfragmentering. Ocksá för tidig slátter av ängar, dvs. före frösättningen och overdrivet uppsnyggande av vâg- och dikesrenar minskar pollinerarnas tillgång till năringsväxter. Detta orsakar näringsbrist för pollinerarna och alternativa näringskällor finns inte. Det har ocksả blivit svárare för dem att hitta lámpliga ställen fờ sina bohálor.

Ekologiskt jordbruk behöver pollinerare, eftersom det i ekologiskt jordbruk anvânds artrika traditionella ângar med mánga insektpollinerade nektarblommor. För att fá ekologiska mjölk- och köttprodukter behövs insektpollinerade växter bàde som bete och foder fôr djuren. Ekologiskt jordbruk borde gynnas ocksa för att det anvannder mindre bekämpningsmedel, som är skadliga ocksá för nyttiga insektpollinerare. Största delen av alla utrotningshotade insektpollinerare är kulturlandskapsarter.

Alldeles ny forskning har gett ny information om lufttöroreningars betydelse. Pollinerarna anvănder bảde sitt syn- och luktsinne för att hitta blommor. Föroreningar frản trafik och industri samt ozon i troposfären gör att de doftande kolvăten som blommorna utsöndrar sönderfaller sả att det blir svarare fớr insekterna att följa blommornas doft och hitta blommorna. Dá pollinerarna máste anvânda lăngre tid pa att hitta blommorna blir deras kondition sämre. Luktsinnets betydelse är storst i fragmenterade och starkt förorenade habitat.

Nya arter som eventuellt sprider sig till Norden pá grund av klimatförändringen kan föra med sig näringskonkurrens med lokala arter. Pả försommaren àr 2007 vandrade en stor svărm stora mellangetingar (Dolichovespula media) ôver Finland. Ocksả den tidigare sällsynta bålgetingen (Vespa crabro) har blivit vanligare i Finland.

Under de senaste âren har det speciellt i USA skett massdöenden av honungsbikolonier. Orsakerna är tillsvidare okända. I Storbritannien och Nederländerna har det observerats minskning ocksả i naturliga pollinerare, bin och blomflugor. Samtidigt har ocksà deras näringsväxter minskat. Ett eventuelit orsakssammanhang har inte kunnat bevisas, men det vore skăl att undersôka fenomenet nogrannare och i flera länder. Det är sannolikt att liknande utveckling forrekommer ocksá annanstans - även i Norden. I Finland är det redan andra sommaren i rad med ovanligt fa bin och humlor. Orsaken till minskningen av dessa pollinerare är inte med säkerhet känd, men de har ôvervintrat däligt efter den ogynnsama sommaren förra äret. Den ovanligt varma vintern och parasiter kan ocksả ha bidragit.

Insektpollinering är en dubbel ekosystemtjänst. Den producerar báde livsviktiga varor och är i frága om frukt- och bärodlingar och vilda bär ocksá en kulturtjānst. Pollinering âr naturens tjānst fơr människan, men ocksả för naturen själv.

Det ekonomiska värdet av ekosystemtjänster är svàrt att mäta. Det skulle ăndả vara viktigt att bestämma ett marknadsvärde, eftersom det är det enda sättet att garantera att tjänsterna inte blir bortglömda i övervägningen av miljönytta och -skada i samband med samhälleliga och kommersiella investeringar.

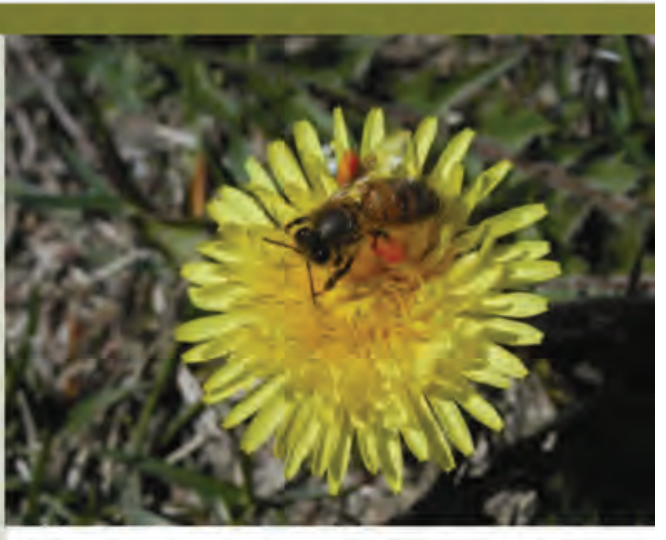

Honungsbiet (Apis mellifera) samlar pollen $i$

pollenkorgarna pà sina ben i en maskros. Växter behöver pollinering for sin förökning. Lyckad pollinering ökar betydligt storleken pá frön, frukter och băr. Honungsbiets betydligt storleken pá frön, frukter och bär. Honungsbiets
betydelse i pollineringen har ökat, dả naturliga pollinerare har minskat. Honungsbin är inte lika effektiva pollinerare som humlor, men deras pollineringseffekt baserar sig pá stora kolonier. Bild: J. C. Schou.

\section{Ekosystemansatsen i all mänsklig verksamhet}

Ekosystemansatsen ăr ett tillvăgagângssätt för att beakta biodiversiteten i markanvändning. Tanken har utvecklats under $\mathrm{FN}$ :s biodiversitetskonvention En av de viktigaste principerna är hällbart utnyttjande av miljön. Ekosystemansatsen utnyttjande av mijon. Ekosystemansatsen habitatskydd pa ett sătt som ocksa beaktar människan och hennes verksamhet. Huvudtanken är att trygga ekosystemens struktur och funktion och därmed tjänsterna som de erbjuder människan som stöd för vălbefinnandet.

\section{Källor:}

- "The Green Lane" Environment Canadas webplats. - McFrederick, Q, et al. 2008: Air pollution modifies floral scent trails. Atmospheric Environment 42:23362348:

-R. Leinonen \& J. Itămies 2008: Työvoimapulaa pölytyshommissa. - NATURA 2/2008, biologian ja maantieteen opettajien liiton julkaisu, 45. vuosikerta, ss. 22-24. (Brist pà arbetskraft i pollinering, artikel pà finska).

- Naturhistoriska centralmuséet, Helsingfors universitet 11.6.2007. Suurikokoisten pensasampiaisten vaellus vyöryi yli Suomen (De stora mellangetingarnas vandring vallde över Finland, pressmeddelande pá finska).

- J. C. Biesmeijer, S. P. M. Roberts, M. Reemer, R. Ohlemüller, M. Edwards, T. Peeters, A. P. Scahffers, S. G. Potts, R. Kleukers, C. D. Thomas, J. Settele, W E. Kunin 2006. Parallel Declines in Pollinators and Insect-Pollinated Plants in Britain and the Netherlands. Science Vol 313, 2 July 2006.
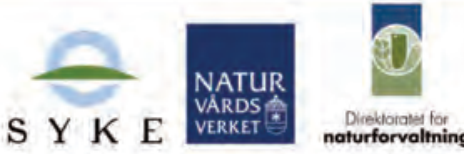$$
\text { MILJØMINISTERIET }
$$

naturforvaltroning
Grønlands Hjemmestyre

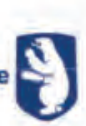

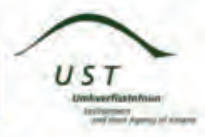




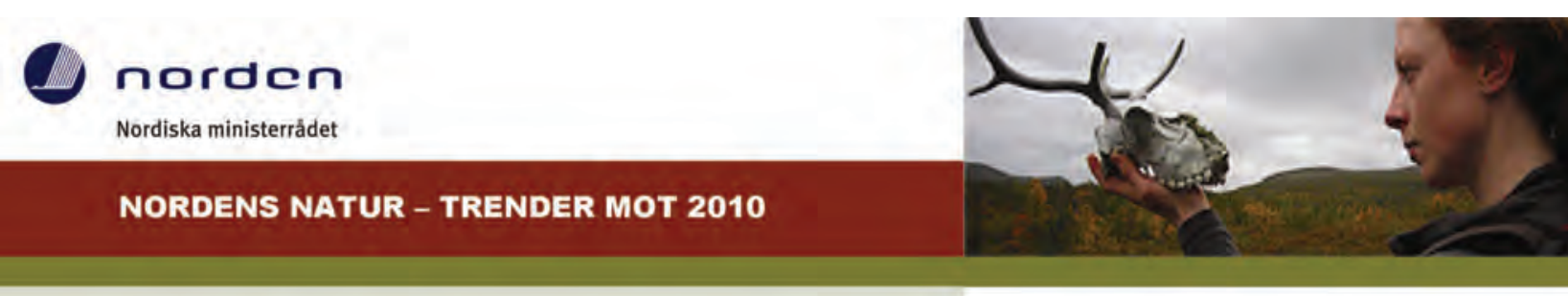

\section{Fiskarternas växelverkan beaktas i Norden - torsk- och sillbestånden i Nordostatlanten}

Nordens havsområden består av Grönlands hav, Norra Ishavet, Norska havet, Nordsjön samt Östersjöns brackvattensbassäng. Pả atlantiska sidan lever c. 200 marina fiskarter och i Östersjön c. 100 fiskarter som anpassat sig till brackvatten. Haven, och fiskbestånden i dem avskiljs från varandra av danska sunden.

Fiskstammarna i nordiska vatten var stora och höll sig på en hållbar nivå så länge som man fiskade med traditionella metoder. Pả 1800-talet ökade yrkesfisket dả metoderna blev effektivare och fiskarna började specialisera sig. I medlet av 1900-talet klarade många fiskbestånd inte mera av överfisket och bestånden kollapsade. Den norska vårlekande sillen är ett exempel pả ett drabbat bestånd.

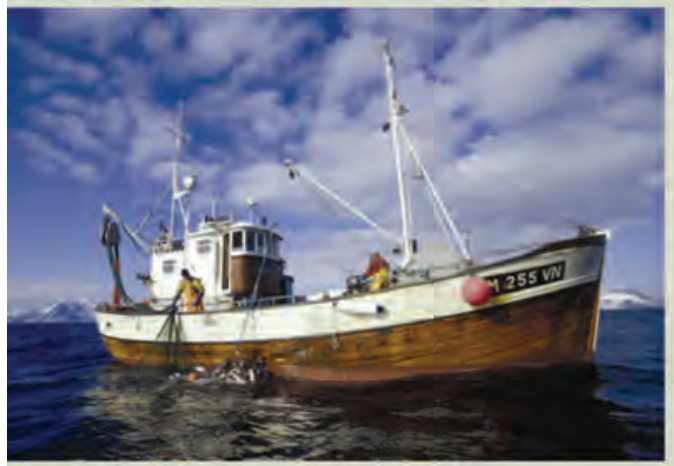

Fiskare med sin fángst. Bild: Samfoto

Målet med staternas gemensamma fiskeripolitik är att utveckla en både biologiskt och ekonomiskt hăllbar fiskerinäring, samt att garantera ren näring åt medborgarna. Tidigare reglerades fisket av fiskbeståndens storlek, men nu reglerar människan fisket genom fångstkvoter och tillfälliga fiskeförbud på vissa områden. Kvoterna är dock ofta rekommenderas av forskarna och överskrids dessutom tidvis. större än vad som

De ekonomiskt viktigaste fiskarterna för nordiska fiskare är torsk (Gadus morhua), sill (Clupea harengus) och lodda (Mallotus villosus). Sillen och loddan är den atlantiska torskens viktigaste föda, och därför är bevarandet av deras bestånd viktigt också för torskbeståndens livskraft. I de nordiska länderna har man också redan i tiotals år beaktat växelverkan mellan arter då fisket regleras. Torsken, sillen och loddan är välkända arter, vars bestånd följs upp noggrannt. Alla är arter som förökar sig effektivt och bestånden kan ăterhämta sig om förhållandena är gynnsamma.

\section{Torskbeståndens återhämtning kräver åtgärder}

Torsken är Nordens och hela världens ekonomiskt mest betydelsefulla fiskart. Den är en genuin bottenfisk, som äter bottendjur och -fiskar. Om det inte annars finns tillräckligt näring kan den också ty sig till kannibalism. Under de senaste 50 åren har torskbestånden växlat kraftigt.

Det största torskbeståndet i nordliga vatten är det nordostarktiska beståndet, som huvudsakligen leker $i$ Nordnorge och lever i Barents hav. Dessutom finns Grönlands och Färöarnas torskbestånd, det isländska beståndet och

Nordsjöns bestảnd i omrădet. Förutom dessa finns ännu mảnga små bestảnd längs med Norges kust, varav kustbeståndet norr om 62 . breddgraden blev klassificerad som hotad ảr 2006 på grund av dess svaga tillstảnd och oeffektiv reglering.

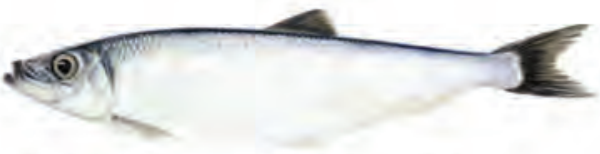

Sill (Clupea harengus). Bild: Jón Baldur Hlidberg

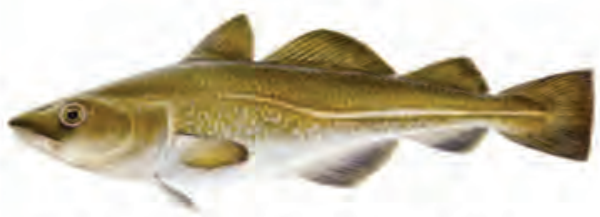

Torsk (Gadus morhua). Bild: Jón Baldur Hliôberg

\section{Torskbestånden i \\ Nordostatlanten}

1000 ton

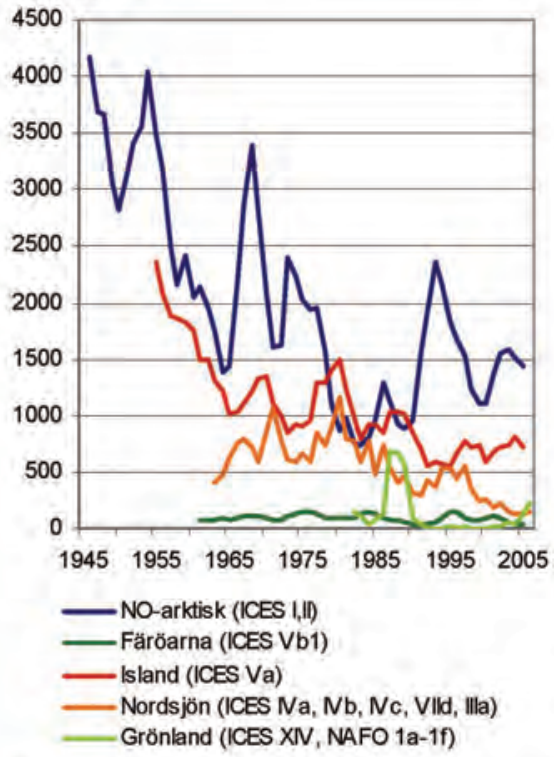

Torskbestánden i Nordostatlanten har utsatts for overfiske och de har lidit av näringsbrist dà huvudsakliga bytsfiskarnas, sillens och loddans bestánd har växlat. Enligt ICES àr förokningen hos till exempel Färoarnas torsk nedsatt och fisket är ohällbart. ICES rekommenderar en àterhämtningsplan för att skydda Färöarnas torskbestánd. Kurvorna visar torskbestándens totala biomassa.

Kallor: ICES Stock Assessment Summaries 2006. NAFO 2007. 
Pả Island fiskades pả 1970-talet dubbelt så mycket torsk som nu. A andra sidan var bestándet större dả än nu. Lekbestándet var ändá mindre än den upskattas vara nu, och fisket reglerades frán och med slutet av 1970-talet. Atgärderna var inte tillräckliga och bestảndet började áterhämta sig först i medlet av 1990-talet tack vare strikta begränsningar av fisket. Beståndet kommer ândầ att hâllas litet ânnu länge pả grund av svag förökning.

Det gick inte băttre för nordostarktiska bestándet pá 1970-talet. Unga fiskar trálades mycket och överfisket ledde till bestảndet kollapsade. Fángstkvoterna överskred fiskebiologernas rekommendationer flerfalt. Torsken led dessutom av näringsbrist dả loddans bestảnd växlade kraftigt. Ett praktexempel pả hur ändringar $i$ arternas bestảnd påverkar varandra. Minskningen av fángstkvoterna pà 1990-talet och loddans bestándstillväxt hjälpte nordostarktiska torskens äterhämtning. Ändả är bestảnden fortfarande svaga pá grund av för stora fiskeinsatser.

I grönländska vatten finns tvà små torsksbestảnd: ett văstligt fjordbestând och ett yttre bestảnd $i$ ôppet hav, som finns bảde pà östra och västra sidan. Fjordbestảndet bestár av flera smá, stabila bestánd och det fảr tidvis tillägg frán det yttre bestándet dả det är stort. Yttre betsåndet var stort ännu pá 1960-talet, men kollapsade totalt i väster i slutet av 1960-talet, dả klimatet blev kallare och pá grund av överfiske. Pả 1980 -talet fick beståndet páfyllning frán Islands torskbestånd och det âterhämtade sig, tills fiskarna átervände till Island för att leka. Sedan dess har man inte fiskat ur beständet och ocksả i oster har fisket varit mycket begrănsat. Under de senaste áren har det igen kommit tvà nya aarsklasser fràn Island till Grönland, som tillsammans med god förvaltning möjligen kan ăterinföra ett lekbestảnd till văstra Grönland. I öster har ett lekbestánd redan konstaterats, och pá den tilläts till och med fiske redan.

Nordsjōn hör till världens mest produktiva fiskevatten. Nordsjôtorsken har under de senaste åren fiskats sá att bestånden har minskat som aldrig förr. De senaste fyra árens rekrytering har varit să svag att det inte finns mycket hopp om att bestảndet skall ăterhămta sig inom snar framtid. Hela bestảndet är nu sả ostabilt att det hotas av en kollaps om inte forskarnas rekommendationer om fiskekvoter följs. Forskarna vid Internationella havsforskningsrâdet ICES rekommenderar att fiskekvoten minskas till $50 \%$ av fângsten ảr 2006. Dả kunde unga fiskar fả en möjlighet att vâxa och föröka sig och torskbestándet kunde áterhämta sig.

\section{Sillbeståndens àterhämtning är exempel på lyckade ătgärder}

Sillen är en nordlig stimfisk. Som băst kan stimmen uppgá till fyra miljarder individer. Den norska värlekande sillen ansảgs tidigare utgöra världens största fiskbestănd. Det kan ha varit sant ännu pà 1950-talet, men sedan

överfiskades sillbestannden i norra Atlanten kraftigt och de gick ner till sả gott som noll, dả mängden könsmogna individer blev allt för lágt. Overfisket möjliggjordes pả 1960-talet av nya fiskemetoder, som snörpvad, ekolodning och utnyttjandet av hydraulik. Sillbestándens nedgáng inverkade ocksá pả torskbestánden, etfersom sillen utöver loddan hör till torskens viktigaste byten. Sillen upprätthöll ocksả flera andra rovfisk-, säl-, val- och havsfägelbestând. Trots bestándens nedgáng avslutades inte silliisket helt, vilket saktade ner bestàndens ảterhämtning. Pả 1980-talet fick man ăndả bestảndet att gả upp igen med hjälp av fảngstkvoter, samtidigt som sillens lek lyckades bra ár 1983.

Ocksâ Islands sommarlekande bestảnd har ăterhămtat sig. Bestảndet har utnyttjats hállbart sedan 1975 och är nu större än nágonsin förut.

Nordsjösillens âterhămtning ăr ett praktexempel pâ god fiskevàrd. Bestảndets kollaps i slutet av 1970-talet ledde till ett fyraảrigt fiskeförbud i Nordsjön. Under de därpáföljande áren ăterhämtade sig beständet snabbt. I takt med bestándets tillvăxt okade ocksá fisket, och beståndet minskade igen pá 1990talet. Ar 1996 minskades sillens fảngstkvoter och efter det beslöts det också om gemensamma rảd för fiskevaarden av sill. Med hjälp av dessa ảtgärder började sillbestảndet văxa och har nu nătt en biologiskt hällbar nivà.

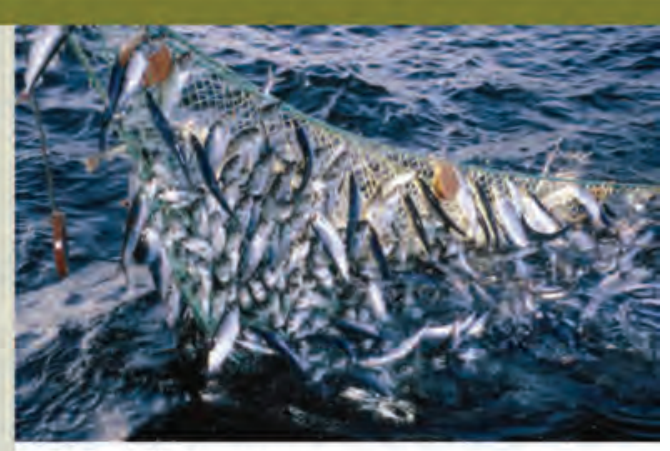

Sillfiske. Bild: Samfoto

\section{Sillens lekbestånd $\mathrm{i}$} Nordostatianten

\section{0 ton}

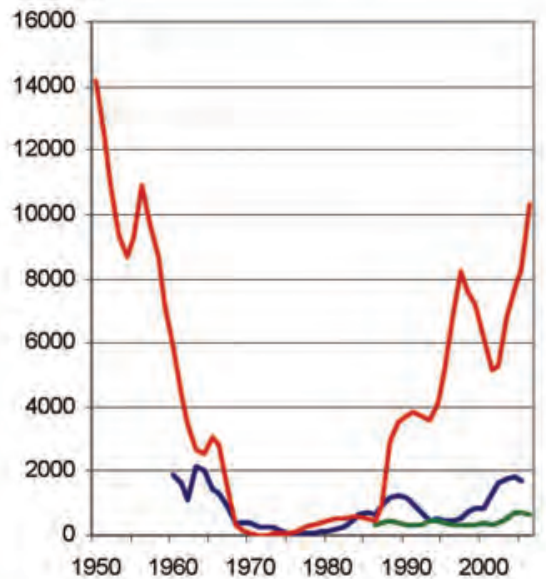

$\begin{array}{lllll}1950 & 1960 & 1970 & 1980 & 1990\end{array}$

- Nordsjön, höstlekande (ICES N, VIld, Illa) - Island, sommarlekande (ICES Va) Norge, värlekande

Den islädska sommarlekande sillen klarade överfisket vid decennieskiftet 1960-1970. Frản och med 1975 har bestándet fiskats igen, men nu arr fisket hällbart. Lekbestánden hos den norska varlekande sillen och Nordsjösillen har âterhămtat sig tack vare intemationella àtgärder. Kurvorna visar lekbestándens biomassa. Källa: ICES Stock Assessment Summaries 2006

Källor:

-ICES. 2006. Report of the ICES Advisory Committee on Fishery Management, Advisory Committee on the Marine Environment and Advisory Committee on Ecosystems, 2006. ICES Advice. Books 1-10. Book 2 Iceland and Greenland. Book 3 The Barents Sea and the Norwegian Sea. Book 4 The Faroe Plateau Ecosystem. Book 6, North Sea.

- ICES CIEM, Environmental status of the European seas, 2003, Federal Ministry tor the Environment, Nature Conservation and Nuclear Safety, Germany. - Hallanaro, Eeva-Liisa, Pylvănäinen, Marja \& From, Stella 2002. Nature in Northern Europe. Nord 2001:13, Nordiska ministerrádet, Köpenhamn.

- Arktisk miljö i Norden. 1996. Nord 1996:21, Nordiska ministerrádet, Köpenhamn

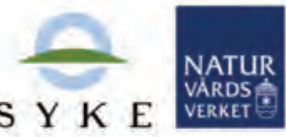

S Y K E

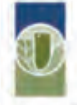

Direjdorate for
naturforvaltming
MILJøMINISTERIET

By-og Landskabsstyrelsen umhvervisstovan
Direktoratet for Miljo og Natur

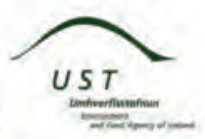




\section{U norden \\ Nordiska ministerrådet \\ NORDENS NATUR - TRENDER MOT 2010 \\ Östersjöns torsk- och strömmingsbestånd - uppehåll i predator-byte -förhållandet}

I Östersjöns brackvatten lever c. 100 fiskarter. De är både havsarter som har anpassat sig till låg salthalt $i$ vattnet och sötvattensarter som anpassat sig till saltvatten. Ekonomiskt är de viktigaste arterna torsk (Gadus morhua), strömming (Clupea harengus v. membras) och vassbuk (Sprattus sprattus). Deras förhållande till varandra är också starkt; torsken är strömmingens och vassbukens främsta predator. $\AA$ andra sidan äter både strömming och vassbuk ibland torksrom och -larver under deras första levnadsmånader. Tillståndet hos en arts bestånd inverkar direkt på de andra arternas bestånd. Nu har den naturliga balansen mellan arterna ändrats, på grund av att torskbestånden redan länge har varit små. Både strömmings- och vassbuksbestånden har ökat, då deras huvudsakliga predator minskat.

\section{Östersjöns torskfiske ohăllbart}

I Östersjön finns två skilda torskbestảnd, som leker på olika områden. Beståndens gräns går vid Bornholm, som hör till Danmark, och kallas enligt sin utbredning det östliga och västliga beståndet. Båda bestånden är hotade både på grund av Östersjöns dåliga tillstånd och överfiske.

Till Östersjön kommer tidvis salt och syrerikt ytvatten från Nordsjön i sk. saltvattenpulser. Efter 1993 har det inte kommit tillräckligt starka saltvattenpulser, som skulle ha hjälpt situationen i den som följd av eutrofiering syrefattiga havsbottnen, eller höjt salthalten $i$ vattnet. Torsken, som är en bottenfisk, lider både av den syrefattiga bottnen och lága salthalten. Den lägger sitt rom i fritt vatten. Rommen sjunker tills den når vatten med en salthalt på 10-12\%o och flyter där. Om vattnet på den höjden är syrefattigt (under $2 \mathrm{ml} / \mathrm{l}$ ) dör rommen. Stora torskhonors romkorn är större och lättare än smả honors och flyter därför högre upp i vattenpelaren, där det finns mera syre, och därmed har stora honors rom en större sannolikhet att utveckals normalt och överleva. Därför är det viktigt att spara stora individer.

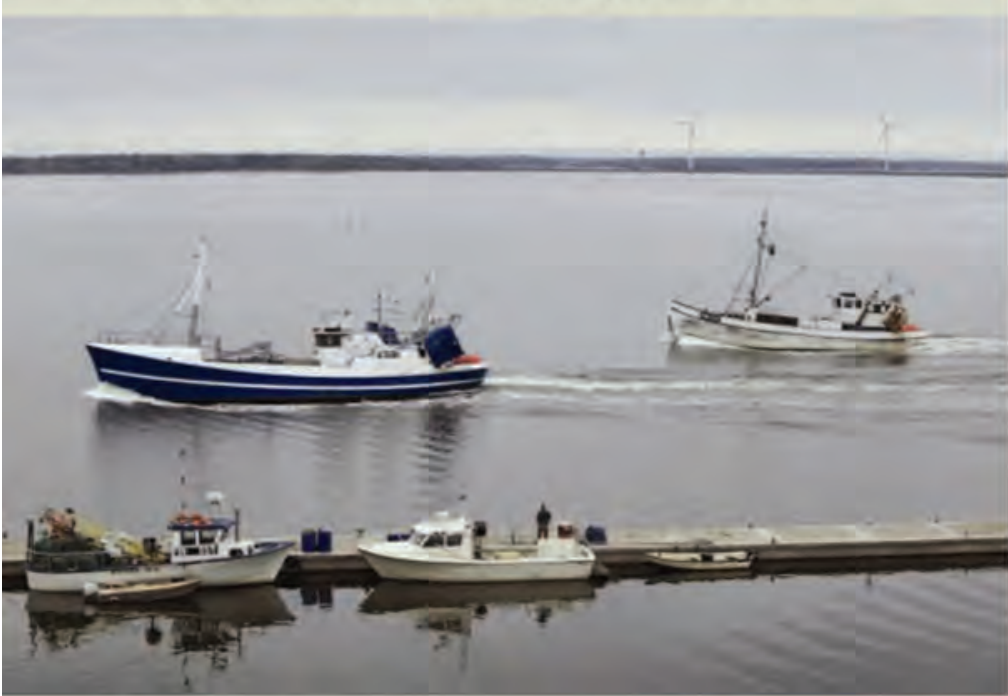

Fiskefartyg pà Ostersjön. Bild: Markku Saiha/leuku.fi
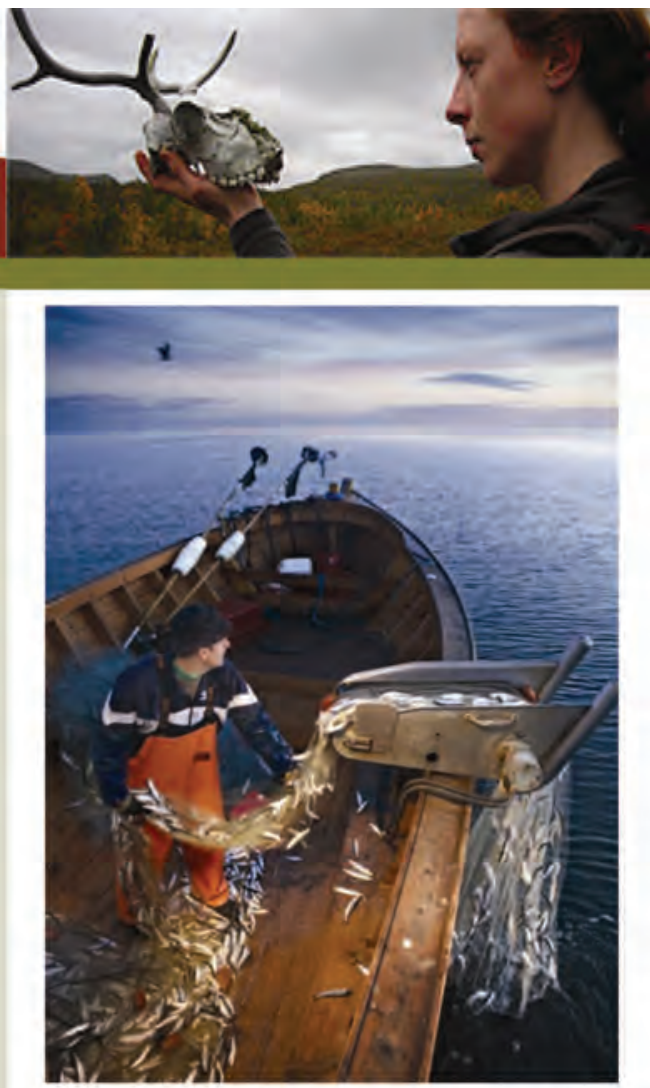

Strömmingsfiske med năt. Bild: Markku Saiha/euku.fi

\section{Torskbestånden i Östersjön} 1000 ton

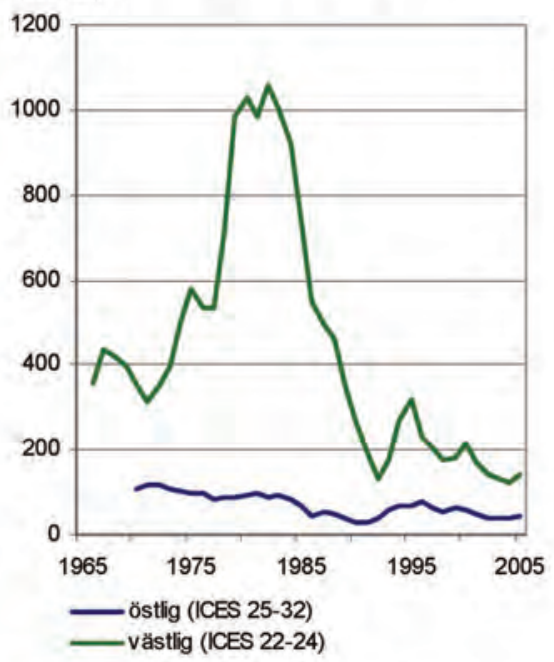

Torskbestánden i Ostersjön behöver internationell reglering fór att àtergá till en hảllbar nivá och ocksá hâllas hảllbara. Europeiska unionen har en administrativ plan för torskbestánden, som de nordiska länderna har plan för torskbestánden, som de nordiska laanderna har bland annat fiskeförbud pá vissa omráden för att skydda lekomráden och unga fiskar. Kurvorna visar torskbestándens totala biomassa. Kalla: ICES Stock Assesment Summaries 2006 
Det östliga torskbestảndet har tre lekomráden: Bornholms, Gdansks och Gotlands djup. Pà grund av Östersjöns nuvarande salt- och syresituation har torskens fórökningsomräde minskat och leken lyckas nuförtiden bara i Bornholms djup. Däremot har det văstra bestanndets lekomráde inte krympt.

Torskbestảnden har minskat stadigt, dả biologernas rekommendationer om fångstkvoter inte har fölits. Internationella havsforskningsrådet ICES ger ärligen rekommendationer om fảngstkvoter och medlemsländerna avgör om de följs eller inte. Fràn det västra bestándet fiskas árligen en stor del av individerna. När för unga individer fángas blir fảngsterna till och med större ẩ lekbeståndet. Det ơstliga bestândets tillstând ăr ännu betydligt sămre. Lekbestándet minskade snabbt efter 1980-talets början och utgör nu bara en tredjedel av den rekommenderade nivăn. Sedan 1990-talet har bestăndet utnyttjats alldeles för starkt i förhâllande till dess tolerans och förökningskapacitet.

ICES har i àr klassificerat det ôstliga bestañndet som ohállbart utnyttjat och lidande av försvagad förökning. ICES rekommenderar fiskeförbud för det östliga bestândet för ár 2008 och uppskattar att förbudet kunde fà lekbeståndet att stiga till en hăllbar nivá tills ăr 2009. Den 23. oktober 2007 godkände Europeiska kommissionens fiskerirád fängstkvoterna och antalet fiskedagar för àr 2008. Kvoten för det västra bestándet minskas med $28 \%$ och östra med $5 \%$. Under kommande ár kommer kvoterna och fiskedagarna att minskas ytterligare tills torskbestảnden nár en hällbar nivà.

\section{Strömming och vassbuk - Östersjöns silverstim}

Strömmingen (Clupea harengus v. membras) i Östersjön är en varietet av sillen (Clupea harengus v. harengus), som har anpassat sig till brackvatten. Den förekommer och förökar sig i hela Östersjön. Söder om Kalmarsund kallas strömmingen av ekonomiska skäl sill. Den är en planktonătade stimfisk, som vandrar bảde fôr att âta och fôr att leka. En annan viktig stimfisk i Östersjön är vassbuken, som förekommer främst i södra och mellersta delarna av Ostersjön. Dả bestándet är stort breder det sig norrut ânda till finska kusten

Strömmings- och vassbuksbestånden har inte kollapsat pá grund av överfiske pá samma sătt som sillbestañden $\mathrm{i}$ Atlanten. Bada arternas beständ växlar kraftigt, vilket har ett samband med torskens bestândsstorlek och näringstillgảng. Det största strómmingsbestăndet lever i egentliga Östersjön. Det här bestàndet minskade frân och med 1970-talet fram till milennieskiftet, men har sedan dess âterhämtat sig stadigt. Trots att beståndens biomassa har minskat, har individantalet hallits stadigt. Strömmingens tillväxt har blivit lángsammare sedan medlet av 1980 -talet. Fiskarna är nu mindre och smalare än tidigare pả grund av näringsbrist och dessutom starkare födokonkurrens som följd av vassbuksbeståndets ökning.

Om fisket hálls pả sin nuvarande nivă förutspäs strơmmingbeståndet $i$ egentliga Östersjön växa fram till àr 2015. Bestảndsstorleken regleras av fiske, naturlig dödlighet samt Östersjöns torsk- och vassbuksbestând. Det ser ut att vara ett uppehåll i predatorns och bytets förhăllande pă grund av torskbeständens däliga tillständ. Bàde strömmingen och vassbuken gynnas av torskbestândens dăliga tillstănd. Om Östersjöns torskbestánd áterhämtar sig kan det bli aktuellt att begraansa vassbuksfisket. Eftersom vassbuk fängas främst tillsammans med strömming máste begränsningarna beaktas specielt pà de omráden där bàda arterna förekommer. Europeiska kommissionens fiskerirảd besıőt ânda hōja strōmmingens fângstkvoter i egentliga Östersjön med $15 \%$

Strömmingen i Bottenhavet gynnades av torskens minskning och beståndet okade till fyrdubbel storlek under ären 1981-1994. Bottenvikens strömming utnyttjades starkt under 1990-talet, och dess tillstảnd nu är oklart. Enligt ICES utnyttjas strömmingen för tillfället hàllbart i Bottenhavet, men i Bottenviken fár fisket inte oka. Europeiska kommissionens fiskerirád beslöt minska fảngstkvoterna i dessa omráden med 4-10 \% för ăr 2008.

\section{Strömmingens lekbestånd $\mathrm{i}$ Östersjön}

\section{0 ton}

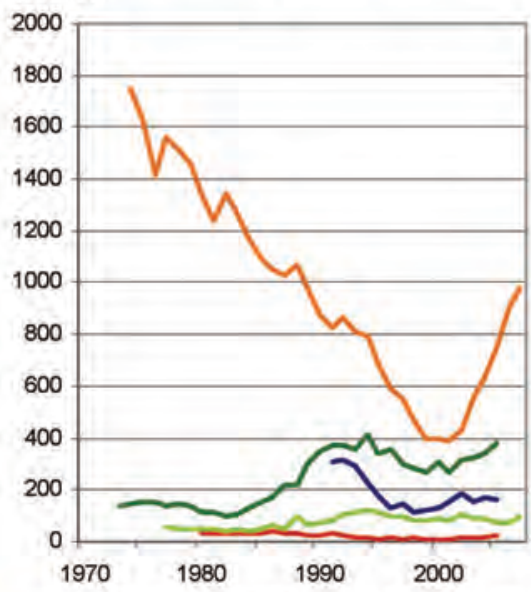

Danska sunden, vảrlekande (ICES Illa, 22-24) Bottenhavet (ICES 30)

Bottenviken (ICES 31)

- Egentiga Östersjön (ICES 25-27, 28-2, 29, 32 ) Rigabukten (ICES 28-1)

Bàde strömmingens och vassbukens bestànd pàverkas av torskbestảndet och av yttre delvis okända faktorer. som tidvis producerar stora ársklasser. Bestàndet i egentliga Ostersjön ăr igen stabilt efter bottenläget i början av 2000-talet. Kurvorna visar biomassan för strömmingens lekbestând. Bildens kâllor: ICES Stock Assessment Summaries 2006.

- ICES. 2006. Report of the ICES Advisory Committee on Fishery Management, Advisory Committee on the Marine Environment and Advisory Committee on Ecosystems, 2006. ICES Advice. Books 1-10. Book 8, Baltic Sea. - Kalavarat 2006 - Fiskresurser 2006. Vilt- och fiskeriforskningsinstitutet, Helsingfors, 2007.79 s. - ICES CIEM, Environmental status of the European seas, 2003, Federal Ministry for the Environment, Nature Conservation and Nuclear Safety, Germany. - Pressmeddelande frán Europeiska kommissionens fiskerirád 24.10.2007, "Commission: Council decision is good for the Baltic cod"

- Hallanaro, Eeva-Liisa, Pylvänäinen, Marja \& From Stella. 2002. Nature in Northern Europe - Biodiversity in a Changing Environment. Nord 2001:13, Nordiska ministerràdet, Köpenhamn.

- Eeva Furman, Harri Dahlström Risto Hamari. 1998 Itämeri - luonto ja ihminen. (The Baltic - Man and Nature). Otava, Keuruu

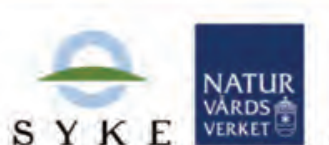

$S Y K E$

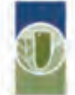

naturforvalthing

\section{Minj..... \\ MILJØMINISTERIET}

By-og Landskabsstyrelsen umhvorvisstovan
Direktoratet for Milje og Natur
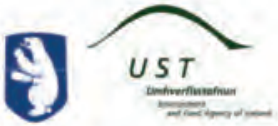


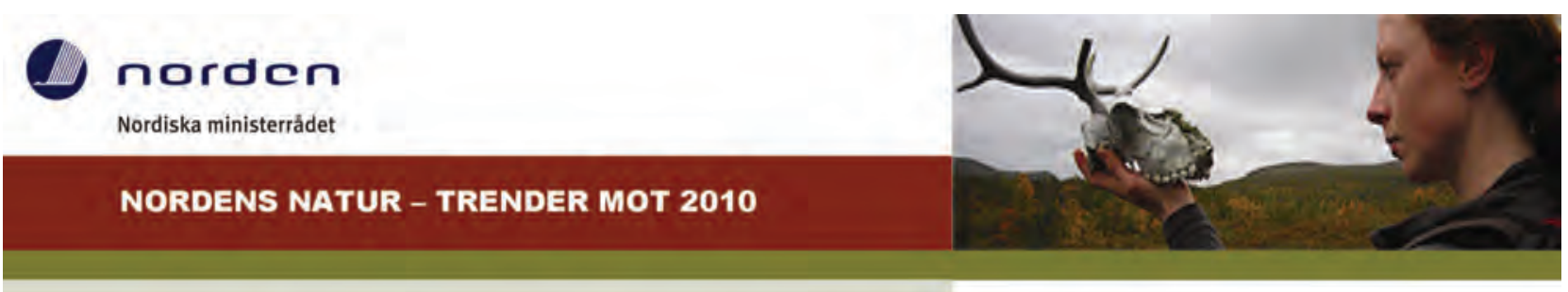

\section{Havsörnens framgångsrika återkomst}

Aterkomsten av Nordeuropas största fágel, havsörnen (Haliaeetus albicilla) är en framgàngshistoria och ett exempel pả att aktiva skyddsátgärder kan rădda arter fràn utrotning. Ännu för 200 àr sedan häckade havsörnen i sá gott som hela Västeuropa, men försvann i slutet av 1800-talet pá grund av förföljning. I medlet av 1900-talet var örnen igen nära att utrotas, men den gảngen var den hotad av miljögifter.

\section{Hoten mot havsörnen orsakas av människan}

Havsörnens utplåning på 1800-talet och under första hälften av 1900-talet berodde helt och hållet på människan. Skottpengar betalades för havsörn ännu ảr 1905 pả Island och pả 1960-talet i Norge. Pả Island dog örnar ocksả av giftfällor som var menade för rävar. Fällorna förbjöds till örnens lycka år 1964.

Havsörnens plats på toppen av näringskedjan blev farlig för den på 19501970-talen, dả miljögifterna DDT och PCB höll pả att utrota den

Förorening av DDT gjorde äggskalen mycket tunna och äggen gick sönder under de ruvande honorna. Användningen av DDT och PCB totalförbjöds i Ostersjöområdet på 1970-talet. Efter att deras användning tog slut tog det några årtionden tills havsörnens förökning återgick till det normala. I Norge var problemen orsakade av miljögifter betydligt lindrigare.

Havsörnar dog också i kvicksilver- och blyförgiftning. Kritiskt höga halter av kvicksilver har uppmätts hos örnar som jagar vid stora konstgjorda bassänger $\mathrm{i}$ Finland ännu under senaste ảren. Det finns kvicksilver kvar i bassängerna ännu flera år efter bygget. Pả Áland hittades i slutet av 1990 talet örnar som dött i blyförgiftning, eftersom förbudet mot att använda blyhagel i sjöfảgeljakten som gavs i Finland 1996 inte gäller pả Âland.

\section{... ännu idag}

Havsörnens dödsorsaker och allvarligaste hot nuförtiden är vindkraftsparkerna som blir allt vanligare längs kusterna och så kallade dödarstolpar dvs. elstolparna närmast stränderna på holmar, som är utmärkta utkiksplatser för örnarna. Då fågeln landar på stolpen kan den genom att röra i kablama med vingarna orsaka kortslutning och dör vanligen direkt. Bland annat från Ảland finns goda erfarenheter av att hindra fågeldöd på grund av stolparna genom att montera en extra balk högst upp på dem, sả att örnarna kan landa säkert. I Sverige har elbolagen isolerat elstolpar och transformatorer med plasthöljen, som hindrar fảgeldöd genom elstöt.

Ändringar i markanvändningen, skogsbruk och byggande av skogsbilvägar är stora hot för havsörnen. Speciellt på Island och i Norge byggs fritidshus, vägar och industri på örnrevir. Ömarna störs ocksả av det ökade fritidsbruket av natur. Häckningsomráden bör följaktligen beaktas i planeringen av markanvändning.

Kollisioner med tåg och bilar dödar ärligen flera havsörnar i Sverige och Norge. Overkörda djur lockar örnar till platsen och dả blir örnarna själv också överkörda. Genom att avlägsna djurkropparna från väg- och järnvägskanterna kunde flera ömar räddas.

Trots att stöming, förföljelse och tjuvskytte har minskat under årens lopp. har de tyvärr inte upphört. Havsörnsägg och -ungar är efterfrågade varor och man har inte fătt slut på samlandet. I Sverige och på Island faller árligen flera örnar offer för tjuvskytte. I Norden är det ett straffbart naturskyddsbrott att döda en havsöm.

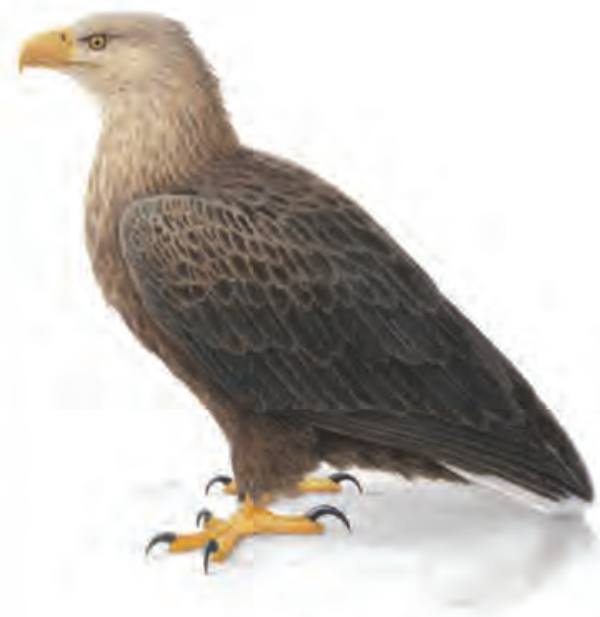

Bild: Jón Baldur Hlioberg

- Förekommer i sydöstra Grönland, västra Island, norra Eurasien ända till Stilla havet och nordvåstra Sibirien

- Sällsynt eller utdőd i Văsteuropa, allmännare i Skandinavien, Finland, Tyskland, Polen och Östeuropa

- Äldre är stannfäglar, en del yngre flyttar frăn Norge och finska och svenska Lappland till Norges kust och frán Östersjöomradet till sydöstra Finland, Aland och mellersta och södra Sverige.

- Häckar vid kusten och vid stora vattendrag

- Bygger pá trădbevuxna omràden ett bo som kan văga upp till ett ton $i$ ett stadigt trăd, pà trädlósa omráden i Norge, pá Grönland och Island byggs boet pà klipphyllor eller pá bar mark.

- Lägger 1-2 ägg, under goda ăr t.o.m. 3.

- Kănslig under hăckning; eftervinter eller mänsklig störning kan avbryta redan pábörjad häckning.

- Plats- och partrogen; det ăr kănt att revir har bebotts i 100-150 ár.

- Huvudsakliga fódan är fisk, fàglar och smà dăggdjur, i Östersjöomrâdet numera även storskarv och grasälskutar.

- Dődar inte renar eller fär, men kadaver duger. 
Också skyddsåtgärderna måste utgả frăn människan

Vinterutfodring av havsörnar, som genomförts inom Finlands och Sveriges havsörnsprojekt har varit en betydelsefull konkret skyddsảtgård.

Vinterutfodringen pábörjades i Sverige och pà Aland redan pả 1960-talet. Svinkropparna som fördes ut till skärgärden och annanstans i terrängen av friviliga utgjorde renare föda för örnarna än den giftimpregnerade naturliga födan.

Speciellt unga fáglar gynnades av vinterutfodringen, som hjälpte dem att klara sig över den första, kritiska vintern. I Sverige fortsătter utfodringen ännu, medan den avslutades av havsörnsprojektet i Finland àr 2000, dả halterna av miljögifter i Östersjön sjunkit under kritiska niváer. Utanför projektet sker en del utfodring fortfarande för att underlätta räkning av fáglarna.

Havsörnens revir och häckning skyddas numera i alla nordiska länder, förutom i Norge, där făgeln är allmän. I skogsskötsel bör örnarnas hăckningsomrảden sparas och botrăd fredas. I Finland ăr trăd mec havsörnsbon alltid fredade. I Finland har det ocksă i avsaknad av lämpliga boträd byggts konstgjorda bon at havsörnar.

Enligt finskt och svenskt exempel startade ocksả Danmark ett örnprojekt år 1992, med mảlet att äterinföra bảde havs- och kungsörn som häckande fáglar i Danmark. Tills ár 2040 ăr mảlet att fá havsőrnsbestándet att växa till 75 hăckande par. Projektet har varit framgảngsrikt, och det finns redan 16 hăckande havsörnspar i Danmark.

Havsörnen ăr en noggrannt uppfolljd art och man strávar efter att ringmärka alla ungar i boen. Ett färgringmärkningsprojekt, som nio nordeuropeiska lănder deltar i startades ảr 1976. Fàglarna räknas frán gömställen vid matningsstationer och ringarna avläses med kikare. Pả ringarna finns information om när och var faglarna är ringmärkta, samt annat som behôvs för vetenskaplig uppföljning.

\section{Framtiden ser ljus ut}

Havsörnens framtid i Norden ser ljus ut, förutsatt att vindmöllornas och elledningarnas dödliga effekter elimineras, förföljningen slutar och markanvândning och lagstiftning utvecklas i rătt riktning. Dessutom behövs frivilliga ocksà i fortsättningen till att genomföra skyddsătgärderna i de nordiska länderna. Trots att det redan finns inofficiellt samarbete, kunde det vara befogat att grunda en samnordisk havsörnsarbetsgrupp. Atminstone kunde det instiftas en nordisk orndag, enligt danskt exempel.

Tabell: Havsörnens status i Norden

\begin{tabular}{|l|c|c|c|c|c|c|c|}
\cline { 2 - 8 } \multicolumn{1}{c|}{} & $\begin{array}{l}\text { Finland } \\
\mathbf{2 0 0 7}\end{array}$ & $\begin{array}{l}\text { Sverige } \\
\mathbf{2 0 0 6}\end{array}$ & $\begin{array}{l}\text { Norge } \\
\mathbf{2 0 0 7}\end{array}$ & $\begin{array}{l}\text { Danmark } \\
\mathbf{2 0 0 6}\end{array}$ & $\begin{array}{l}\text { Färöarna } \\
\mathbf{2 0 0 7}\end{array}$ & $\begin{array}{l}\text { Grönland } \\
\mathbf{2 0 0 7}\end{array}$ & $\begin{array}{l}\text { Island } \\
\mathbf{2 0 0 6}\end{array}$ \\
\hline Namn & merikotka & havsorn & havørn & havørn & havørn & nattoralik & hafớn \\
\hline Par & $\begin{array}{c}271, \text { varav } \\
88 \text { páAland }\end{array}$ & 500 & $3500-4000$ & 16 & 0 & $150-200$ & 63 \\
\hline $\begin{array}{l}\text { Status } \\
\text { (UUCN LC) }\end{array}$ & sărbar & missgynnad & inte hotad & sárbar & $\begin{array}{c}\text { inte } \\
\text { bedömd }\end{array}$ & sárbar & $\begin{array}{c}\text { starkt } \\
\text { hotad }\end{array}$ \\
\hline Fridlysning & $\begin{array}{c}\text { Aland 1924, } \\
\text { Finland } \\
1926\end{array}$ & 1924 & 1968 & 1922 & 1964 & 1973 & 1914 \\
\hline
\end{tabular}

Finlands miljöcentral SYKE - www miljo. fi/nordensnatur

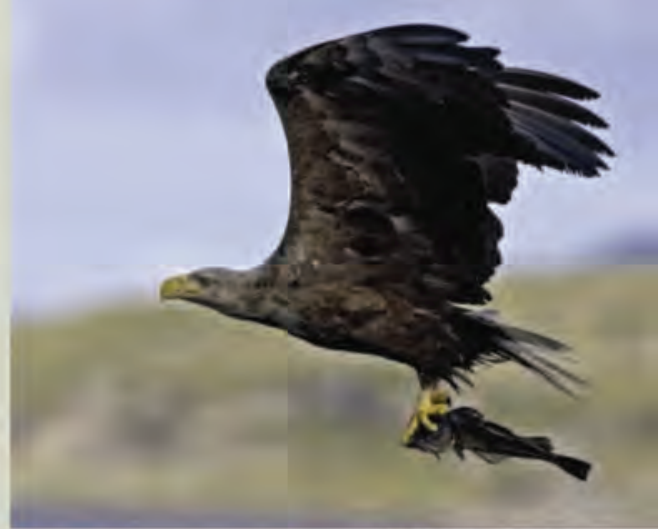

Bild: Jorma Tenovuo

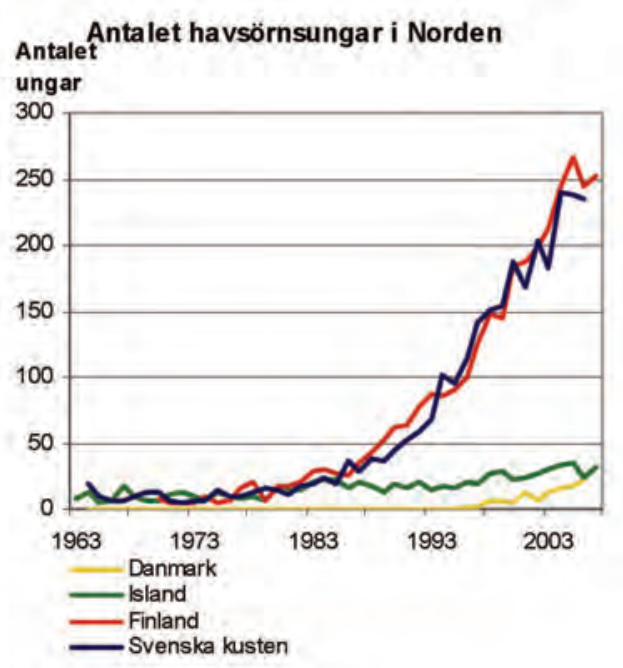

Mest havsörmar i Norge

Havsörnspopulationen pá Grönland ăr stabil och i alla andra nordiska länder växer populationema, vilket kan ses ocksà i de ókande antalet ungar. För tillfället finns $c$. 4500 par i Norden, varav c. 3500 häckar i Norge. Pá Färöarna häckar inga havsömar, och expertema är oense om den nàgonsin har gjort det. Obervationer finns ằndâ, och belägg för att örmar har skjutits. Norges havsörnspopulation är den största i Europa och sáledes havsörnspopulation är den största i Europa och sáledes
har Norge ansvar för hela den europeiska populationen. Ungar fràn Norge har ocksá exporterats till Skottland och Irland, där de lokala populationema har dött ut. Kallor: Finland - Torsten Stjernberg, WWF Finlands havsörnsarbetsgrupp, Sverige - Bjöm Helander, Naturhistoriska riksmuseet, Stockholm, Danmark Ehmsen, E \& L. Pedersen (2006): Arsrapport for Projekt Øm 2006, Dansk Omitologisk Forening, Island - Kristinn $H$, The Icelandic Institute of Natural History

Litteraturförteckning pả faktabladets hemsida: www.miljo.fi/nordensnatur $>$ Faktablad $>$ Havsörnens framgângsrika âterkomst

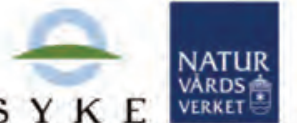

S $Y K E$

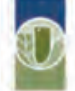

Diebiorates for
noturforvalthing

\section{MILJØMINISTERIET}

By-og Landskabsstyrelsen umhvorvisstovan
Direktoratet for Miljo og Natur
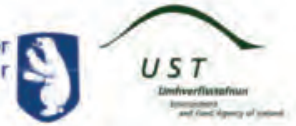


\section{A norden \\ Nordiska ministerrådet \\ NORDENS NATUR - TRENDER MOT 2010 \\ Isbjörnen - på toppen av den arktiska när- ingskedjan och beroende av havsisen}

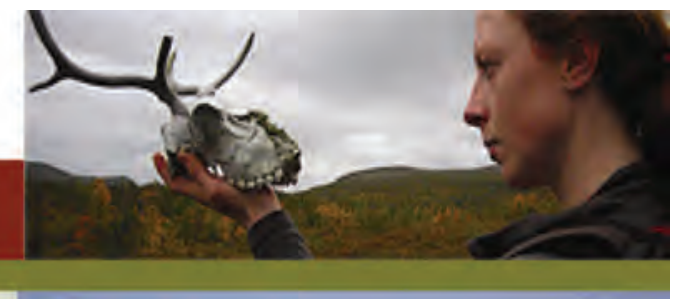

Alla hoten mot isbjörnen är orsakade av människan. Det värsta hotet är den tilltagande klimatuppvärmningen som leder till att havsisen minskar. Andra hot utgörs av giftiga föreningar, eventuella oljeutsläpp och den ökande fartygstrafiken $i$ arktiska omraden samt av jakt och störning. Norden har ett stor ansvar för artens bevarande, eftersom tvá av de fem länder där isbjörnen förekommer är nordiska länder.

\section{Ett karismatiskt offer för klimatförändringen}

Isbjörnen hotas av att havsisen minskar som en följd av att klimtet blir varmare. Havsisen formas senare än förut, täcker ett mindre område och iskanten drar sig också tillbaka tidigare. Detta innebär att isbjörnen på vissa områden tvingas tillbringa en längre tid på land, borta från dess bästa jaktmarker på iskanten.

Isbjörnen är beroende av havsisen, där den jagar sälar och kutar. Från dem făr isbjörnen livsviktigt fett, som hjälper den att klara den isfria perioden dả det finns knappt om föda. Fettreserverna som honorna samlar på sig möjliggör deras fasta medan de föder och tar hand om ungarna.

Under isfria perioder äter isbjömen fåglar, făgelägg och fisk. I sydligaste delen av utbredningsomrádet har isbjörnen lidit av näringsbrist på grund av den allt kortare tiden med havsis. Dá det råder näringsbrist kommer isjörnar oftare till människans bosättningar och de har setts leta efter föda i avfallshögar.

\section{Miljögifters skadliga effekter}

I arktiska områden är koncentrationema av miljögifter höga och gifterna ansamlas till näringskedjans topp. Isbjörnama intar stora mängder långlivade organiska föreningar (POP-föreningar) i sin föda. Föreningarna har konstaterats orsaka stömingar i immunsystemet och hormonfunktionerna, som i sin tur reglerar bl.a. förökningen och anpassningen till förändrade förhållanden.

Gifterna ansamlas i isbjörnarnas fettvävnad, som de utnyttjar medan de lever på land. Därför stiger gifthalterna speciellt under fastan och orsakar problem med matsmältningen och försvårar isbjörnarnas överlevnad. Ungarna intar höga halter miljögifter redan i modersmjölken. Ett slut pà utsläppen av miljögifter skulle främja isbjörnens överlevnad.

Olje- och gasproduktion kan ha allvarliga följder för arktiska områden och för isbjörnen. Oljeutsläpp kan kladda isbjörnarnas päls och därmed försvaga dess isoleringsförmåga. Oljan kan dessutom orsaka förgiftningar då isbjörnar äter neroljad föda eller putsar sin egen päls.

Då isbjörnshonor på Svalbard och Grönland făr halsband med satellitsändare för uppföljning av deras rörelser samt bobygge och förökning, tas samtidigt också blod-, fett- och vävnadsprover för miljögiftsundersökningar. Honorna mäts och vägs ocksả. Inverkan av klimatförändring och miljögifter undersöks i syfte att reda ut om isbjörnen har en möjlighet att anpassa sig till ändringar i sin livsmiljö.

\section{Jakt}

Europeiska valfångare anlände till Grönland och Svalbard på 1600-talet. Snart efter det följde också andra jägare och utnyttjare av naturresurserna. Isbjörnar jagades för köttet och pälsen, men ocksả som rekreation. Grönlänningar har alltid jagat isbjörn för sin egen försörining. Jakten pả Grönland regleras numera av fảngstkvoter, som är lägre än tidigare fảngstmängder. Det är ändả osäkert om jakten pả de bristfälligt kända populationerna är hảllbar.

Pả Svalbard pågick isbjörnsjakten fram till ăr 1974, då jakten där blev totalt förbjuden. Det är ändả tillåtet att döda individer som hotar människor eller egendom. I andra delar av isbjörnens utbredningsområde är jakt tillătet enligt kvoter, som visserligen kan vara för höga i förhållande till populationernas bärkraft.

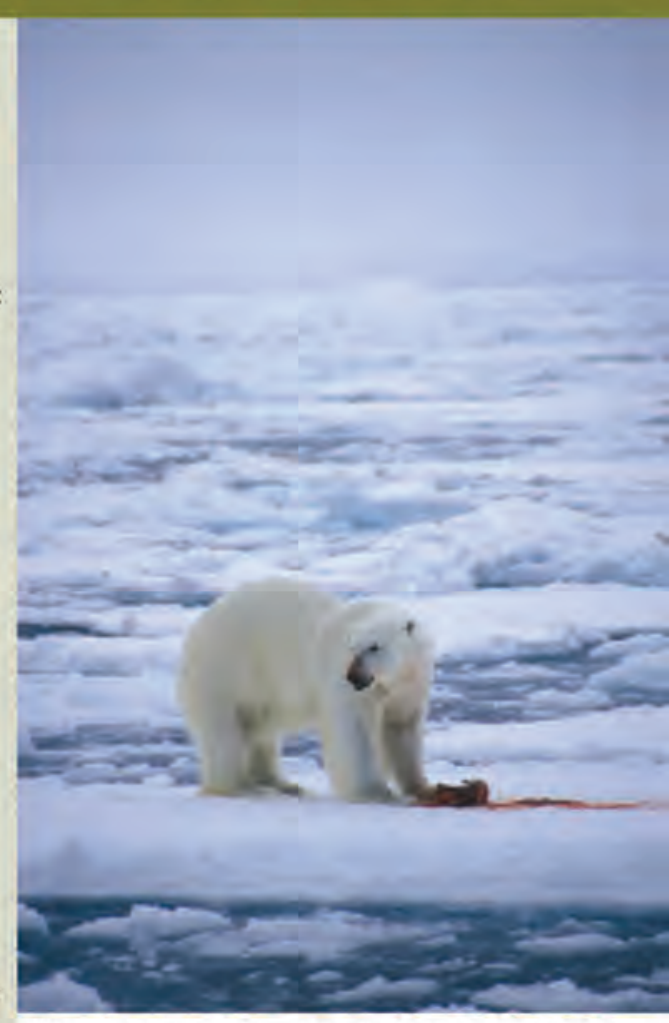

Isbjörnen (Ursus maritimus) ăr isens björn pá alla nordiska sprák, polaromrádets björn pá engeiska och havets björn enligt sitt vetenskapliga namn. Alla namnen ár befogade, eftersom isbjömens livsmilö är havsisen pá norra polaromràdet, och den lever pá fóda frán havet. Bild: Magnus Andersen/Norsk Polarinstitutt

Havsisens vita jätte - isbjörnen (Ursus maritimus)

năra släkt med brunbjörnen (Ursus arctos)

- världens största fyrfotade köttătare

- cirkumpolăr utbredning; förekommer pá norska Svalbard, Grönland, arktiska omraden i Kanada, Ryssland

- sporadiska observationer ocksà pá Island, den senaste ár 1993

- hanen kan văga upp till ett ton och bli 40 àr gammal

- honan föder 1-3 ungar vart tredje âr, varav 30-50\% uppskattas överleva till vuxen alder

- födan bestár av sălar, vikare och deras kutar, andra dăggdjur, som valrossungar och vitvalar och under isfri tid havsfäglar, gäss, eiderägg, fisk och valkadaver, äter även băr, örter och kelper, pà Svalbard ocksả svalbardsren

- helt beroende av havsisen som sin livsmiljö, och av den feta födan som den fängar pá isen

- handel med produkter tillverkade av isbjörn kräver tillstand enligt CITES-avtalet våstra och norra Alaska och i norra delarna av 


\section{Turism $\mathbf{i}$ isbjörnens livsmiljö}

Turism är huvudnåringen på Svalbard. Árligen besőker c. 40000 turister det karga, nordliga omrädet och tar sig fram pá kryssningsfartyg eller med olika terrängfordon eller vandrande. Det har kunnat pävisas att snöscootrar stör isbjörnar redan pả en kilometers avstánd och honor med ungar pa ännu längre avstand. Isbjörnarna är nyfikna djur och de söker sig gärna till nykomlingar och deras tält och kan sảledes bli skjutna i mănniskans självförsvar.

För att skydda isbjörnens livsmiljöer frăn människans verksamhet har det grundats skyddsomráden bảde pả Grönland och Svalbard. Pả sả sătt gár det att undvika onödig störning och möten mellan människor och isbjörnar.

\section{Skyddsåtgärder}

Alla fem länder $i$ isbjörnens utbredningsområde har undertecknat skyddsavtalet för isbjörnar (Oslo 1973). Avtalet strävar efter att skydda isbjörnen samt dess livsmiljö och att garantera ett hällbart utnyttjande av isbjörnspopulationerna. De deltagande länderna utbyter kunskap och samarbetar $i$ isbjörnsskydd, -forskning, -uppföljning och -förvaltning.

Norge tog sitt första steg i skyddet av isbjörn redan ảr 1923, dả en lag stiftades om att honor med ungar fredas. Lagen var i kraft till âr 1974, dâ isbjörnen fredades helt i Norge. Pả Grônland stiftades ár 2005 en lag som förbjuder störning under förökningsperioden och fredar honor med ungar. Samtidigt togs jaktkvoter i bruk pả Grönland. Pà Island reviderades lagstiftningen ár 1994 till att förbjuda dödande av isbjörnar, förutom om de hotar mănniskor eller boskap.

Världens naturskyddsförbund (IUCN) klassificerade ár 2006 isbjörnen som globalt sårbar, eftersom dess isbjörnsarbetsgrupp (PBSG) förutspär en 30 \% minskning av den globala populationen under kommande 45 ăr, pă grund av klimatförändring och miljögifter. Ocksả pả Grönland och Svalbard ăr isbjörnen klassificerad som sărbar.

Arktiska länderna erkänner alla behovet av regelbunden uppfölining av isbjörnspopulationerna. Storleken av en del av populationerna, t.ex. den pả östra Grónland har aldrig uppskattats noggrannt. Grönland har nu tillsammans med Norge startat en undersökning där isbjörnarnas rörelser pả havsisen följs med. Undersōkningen kommer att producera vărdefull kunskap för kommande populationsuppskattningar.

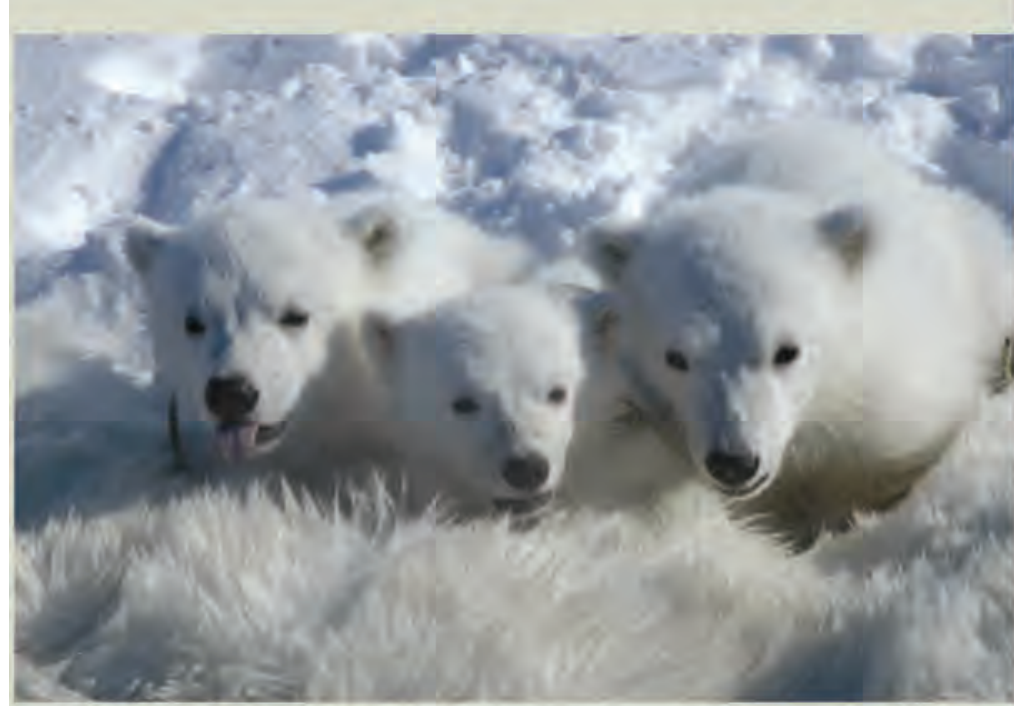

Isbjörnsungar. Bild: Jon Aars/Norsk Polarinstitutt
Antal isbjörnar dódade pà Svalbard och Grönland

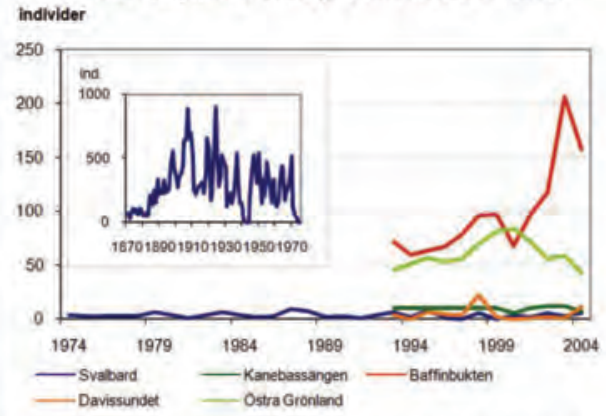

Isbjörnsjakten var som intensivast pá 1800-talet. Numera dödas c. 1000 individer árligen, varav största delen av ursprungbefolkningar som en del av den traditionella kulturen. Grafen visar antalet dödade isbjömar pá Grönland och ren. Grafen visar antalet dödade isbjömar pà Grönland och
Svalbard, $i$ lilla grafen Svalbard före àr 1974. Kăllor: Svalbard: Norsk Polarinstitutt 17.12.2007. Grönland: Aars, J., Lunn, N. J. \& Derocher, A. E. 2006. Fullständiga referenser i faktabladets litteraturförteckning.

Nordiska isbjörnspopulationernas tillstánd

\begin{tabular}{|l|r|c|l|}
\hline Population & $\begin{array}{l}\text { Uppskattat } \\
\text { antal }\end{array}$ & $\begin{array}{l}\text { Uppskatt- } \\
\text { ningens } \\
\text { tidpunkt }\end{array}$ & $\begin{array}{l}\text { Observerad eller } \\
\text { forutspảdd trend }\end{array}$ \\
\hline Barents hav & $2997^{*}$ & 2004 & bristfallligt känd \\
\hline Östra Grönland & okänd & - & bristfalligt känd \\
\hline Kanebassängen & 164 & 1998 & minskar \\
\hline Baffinbukten & 2074 & 1998 & minskar \\
\hline Davissundet & 2252 & 2007 & prognos utarbetas \\
\hline $\begin{array}{l}\text { Arktiska bas- } \\
\text { sängen }\end{array}$ & okänd & - & bristfälligt känd \\
\hline
\end{tabular}

- cirka hälften av populationen pả Svalbard

- bara tillfalliga individer i arktiska bassängen

- populationerna i Kanebassängen, Baffinbukten och

Davissundet är gemensamma för Grönland och Kanada

IUCN uppskattar att 5 av alla 19 isbjörnspopulationer minskar och 7 ökar eller är stabila. Situationen för de resterande 7 kan inte bedömas, eftersom kunskapen om dem är bristfällig. Utvecklingen av populationen i Barents hav är dáligt känd, och den skall uppskattas pá nytt àr 2009. Storleken av östra Grönlands population skall uppskattas genom flygräkning ár 2010. Ny forskning visar att ocksá populationen i Davissundet, som är gemensam forr Grönland och Kanada möjligen okar. De tvà andra genemsamma populationada, mojigen okar. De tva andra genemsamma popu minskar pà grund av för mycket jakt.

Källor: Davissundet: Peacock, E. 2008. Alla andra populationer: Aars, J., Lunn, N. J. \& Derocher, A. E. 2006. Fullständiga referenser i faktabladets litteraturförteckning.

Alla referenser är listade i litteraturförteckningen pả faktabladets hemsida: www. miljo.fi/nordensnatur > Faktablad > Isbjörnen - pá toppen av den arktiska näringskedjan och beroende av havsisen.

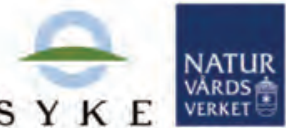

S Y K E

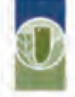

Diredioratel for
naturforvaltning

\section{MILJØMINISTERIET}

By-og Landskabsstyrelsen umhvorvisstovan
Direktoratet for Milje og Natur
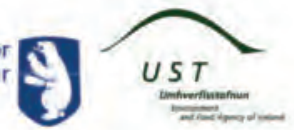


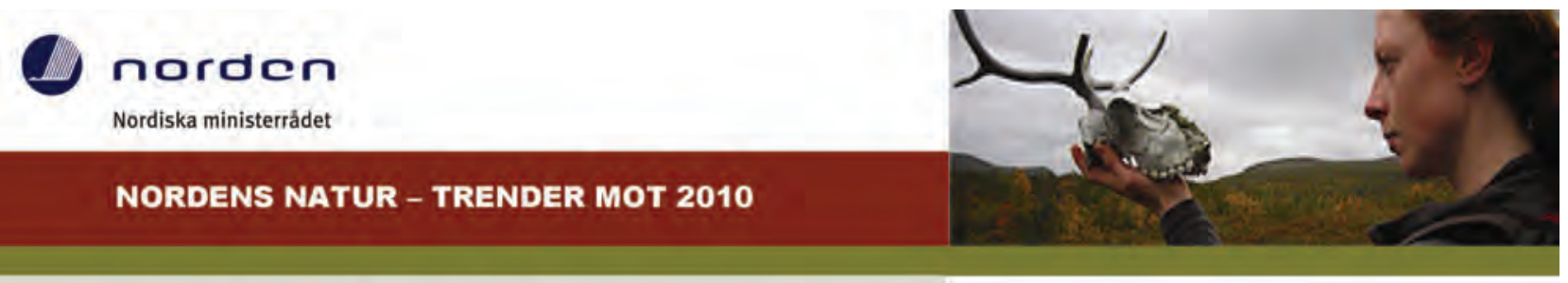

\section{Nordens unika lantraser}

Lantraser och -sorter är gamla husdjursraser och odlingsväxter som i sällskap av människan har utvecklats ur vilda djur och växter. De har utvecklats pă smà omráden före den moderna förädlingens tidsålder. Genom långvarigt naturligt och mänskligt urval har de anpassat sig till lokala förhållanden, så som klimat. jordmån, skadedjur, växtsjukdomar och landskap. De är unika tack vare sin rika mångfald, som har utvecklats under årtusenden.

Människan har spridit odlingsväxter och husdjur över hela jorden och därför är deras utbredningsområden betydligt större än den naturliga utbredningen. De nordiska odlingsväxterna och husdjuren härstammar från över 10000 år tillbaka, från de första fasta mänskliga bosättningarnas tid.

Hos de nordiska odlingsväxterna och husdjuren finns drag av de nordeuropeiska varianterna. Odlingsväxterna har flera ursprungsomráden, där jordbruket har utvecklats oberoende av varandra. Nordens odlingsväxter härstammar från främre Asien. Också flera av de nordiska husdjursraserna, t.ex. får och getter samt möjligtvis också svin och nöt härstammar från samma område. I arvsanlagen hos svin och nöt finns ocksả spår av vildsvin och den europeiska uroxen (Bos primigenius). Europa är ett diversitetscentrum för flera husdjursarter; en tredjedel av världens nuvarande nöt- och svinraser och nästan hälften av alla hästraser är europeiska. De nordiska lantraserna är värda att bevaras för sin genetiska măngfald, trots att Norden inte är deras ursprungsområde, eller ens ett betydande spridningscentrum.

\section{Mângfalden minskar}

Mångfalden, som hos odlingsväxterna och husdjuren har utvecklats under tusentals år, började minska då jordbruket blev effektivare och mer globalt. Många lokala växter fick ge vika för nya sorter och husdjuren förädlades med hög produktivitet som främsta mål. Som följd av att jordbruket har blivit enformigare håller frömaterialet för odlingsväxternas lantsorter på att försvinna. De fả lantsorter som finns kvar måste skyddas, och deras korsning med inkomna sorter måste hindras. Numera utgör bara c. 30 arter säd och rotfrukter $95 \%$ av människornas näring och endast åtta växtarter står för $75 \%$ av vår kost. Största delen av vår animaliska föda utgörs av endast fem husdjursarter: nöt, svin, fảr, get och höna.

Flera lantraser av husdjur är utrotningshotade och en del har försvunnit helt, som t.ex. det finska lảnghăriga lantrassvinet. Enligt FN:n livsmedels- och jordbruksorganisation FAO försvinner en husdjursras varje månad. Det finns knappt om kunskap om flera av de försvunna raserna, men det går att namnge minst 100 försvunna raser. Största delen av de försvunna raserna ăr hönor, nöt och hästar, som är de husdjursarter som förädlats mest. Orsaken till lantrasernas minskning är deras lägre produktivitet jämfört med de allmännare raserna, förändrade jordbruksmetoder och globalisering. Det breda spektret av husdjursraser håller pă att ersättas av năgra västeuropeiska och amerikanska raser, som inte täcker husdjurens hela genetiska variation.

Systematisk förädling av växtsorter och djurraser har pågått i Norden sedan början av 1900-talet. I modern förädling utnyttjas mångformiga ärftliga egenskaper för att utveckla sjukdomsresistenta, produktiva och snabbt förökande raser och sorter. Lantraserna och -sortena är genbanker, som förädlarna också i fortsättningan kan ty sig till om förädlingen hamnar i en àtervändsgränd. Tillsvidare har förädlingen lyckats i sitt mål med att förbättra produktionsegenskaperna.

\section{Skydd av lantraser och -sorter}

Minskningen av det genetiska materialet uppmärksammades i Norden redan i början av 1900-talet, men lantrasernas och -sorternas värde förstods först då en del av lantsorterna redan hade försvunnit från odlingarna. Ár 1979 grundades Nordiska genbanken, numera Nordiska genresurscentret (NordGen) i södra Sverige, för att trygga tillgången till den speciella, till nordiska förhållanden anpassade genetiska mángfalden för livsmedelsproduktionens,

\section{Genetisk màngfald}

- Genetiska mángfalden är en av de tre nivảerna av biologisk mangfald. De tvà andra ăr artmangfald och ekosystemens mángfald.

- Genetisk mangfald är grunden till skillnader mellan arterna och samt grundförutsättningen för arternas utveckling.

- Mảngfalden gör det möjligt för arterna att anpassa sig till forrändrade förhallanden $i$ omgivningen.

- Màngfalden är ocksá en förutsăttning för förädling; samband med förădling det gár att vălja önskade egenskaper, sả som hög produktivitet och motständskraft mot sjukdomar och skadegörare.

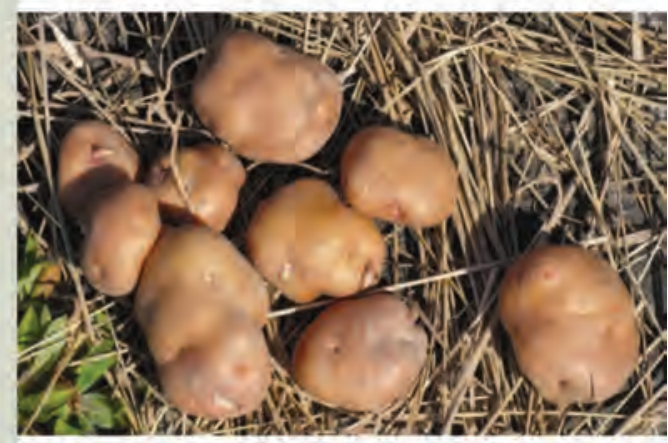

Lantsortspotatis

Potatisen, som härstammar frán Sydamerika, hämtades till Norden pá 1700-talet. Ur nykomlingen utvecklades sá smáningom talrika lantsorter, varav flera hundra uppskattas finnas kvar i de nordiska länderna. Lantsorterna ger mindre skördar och är mera mottagliga för sjukdomar än moderna potatissorter. De är oregelbundna till formen och moderna potatissorter. De är oregelbundna till formen och
svára att skala, men de smakar mera potatis. Vissa sorter har ett djupare vilostadium före groningen an moderna sorter, vilket gör att de hàller sig utan att gro lángt in pả vàren, dà sáningsperioden i Norden börjar. Ar 2008 ăr internationellt potatisens ár. Syftet är att framhäva potatisens viktiga roll som näringsvâxt $i$ kampen mot hungerstisens viltigar poll som not nod och fattigdom. Bilden visar en finsk lantsortspotatis, Lemin punanen (Lemi röda potatis) Bild: Merja Hartikainen/MTT.

Norsk röd lantrasnöt (Vestlands raudkolle)

Det ródbruna, hornlösa norska vestlandsnotet uppkom i början av 1900-talet genom föradling av lyngdals- och rogalandsraserna. Man bes/öt att hàlla den hornlösa rasen ren, dà man pá 1980-talet inság vikten av att bevara de gamla lantraserna. Hornlöshet är en dominant ărftlig egenskap som främst förekommer hos lantraser. Den västländska kon är liten. Vid sekelskiftet 1800-1900 văgde en văstländsk ko bara c. $300 \mathrm{~kg}$. Nuvarande individer väger c $450 \mathrm{~kg}$, medan t.ex. en Ayshire-ko väger c. $550 \mathrm{~kg}$. Ansvaret för rasens bevarande hör till norska genresurscentret, men lyckligtvis văljer ocksả en del intresserade jordbrukare att hálla rasen pà sina bondgârdar. Numera finns det 313 kor och 29 avelstjurar av văstländska rödbruna notet Det ár viktigt att sprida information om gamla jordbruksmetoder och lantraser för att bevara de gamla lokala raserna. 
förädlingens och forskningens behov samt för kommande generationers bruk. I centrets samlingar ingär förädlade sorter, lantraser och odlingsväxter, samt deras vilda slaktingar.

FAO:s handlingsprogram för växtgenresurser och FN: n konvention om biologisk mảngfald förpliktigar till skydd och hállbart bruk av genresurser. Genom skydd av lantraser och -sorter tryggas den genetiska mảngfaldens fortbestând.

Det bästa săttet att skydda lantsorter av odlingsväxter ăr att odla dem pá bondgårdar (âkergenbank) och i trädgârdar pả sina ursprungliga växtplatser, eller sả nāra dem som möjligt. Man kan ocksả "odla" vâxter pả konstgjort underlag i provrör. Frón förvaras i genbanker och i laboratorier antingen djupfrysta i flytande kväve eller i förhállanden dăr tillväxten är längsam. Ar 2008 grundades pá Svalbard ett globalt frövalv för jordens odlingsväxter. Vaaxtgenbanken, som ocksâ kallas Noaks ark eller Domedagsvalvet ăr ett reservlager för alla vărldens fróbanker. Tidigare fanns reservlagret för Nordiska genbanken i en övergiven gruva i permafrosten pá Svalbard.

Uppsvinget $i$ det ekologiska jordbruket hjälper ocksả bevarandet av lantsorterna av odlingsvâxter. Lokala sorter lämpar sig ofta băttre till ekologisk odling än till konventionell odling, eftersom de klarar sig med mindre gödsling ân de moderna sorterna.

Det genetiska materialet hos ursprungliga husdjursraser bevaras i levande djur pâ bondgărdar samt $i$ embryo- och könscellbanker. EU understóder uppfödning av lantraser genom landsbygdens miljóprogram i syfte att upprätthâlla raserna. Lantraser av husdjur anvands numera i skötseln av naturskydds- och rekreationsomraden, eftersom de klarar sig pả näringen frán naturbetet. Som blandboskap âter de vegetationen mảngsidigt och i naturskyddsarbete är hög produktivitet inte nödvändigt. Levande djur och växter kan ocksả flyttas frản sina naturliga utbredningsomráden till nya omráden för skydd. Ett exempel pà dylikt ăr ett försők att flytta det mörka nordiska biet (Apis mellifera mellifera) fràn Læsø i Danmark till Sydgrönland, där det inte annars förekommer honungsbin, utan endast tvà arter humlor. Nordiska husdjursgenbanken (NGH) grundades 1984 för att bevara lantrasernas genetiska mángfald.

\section{Lantraserna och -sorterna en del av vår kulturhistoria}

Lantsorter av vâxter är en del av văr kulturhistoria. Nyttoväxternas odlingshistoria samt tidigare kulinariska värden gár att utläsa ur gamla sorternas egenskaper. Utseendet berättar ocksả om estetiska uppfattningarna hos dem som odlat dem, och därför skulle deras försvinnande vara en kulturhistorisk förlust. Lantraserna och -sorterna bör bevaras bảde för sin genetiska mángfald och för sitt kulturhistoriska värde, men ocksá för forskningens och undervisningens behov.

Bevarandet av den genetiska mängfalden hos lantraser av husdjur och lantsorter av odlingsväxter borde bli en av mälsăttningarna i jordbrukspolitiken i alla länder.

Tabell: Antalet lantraser av de olika husdjuren i Norden.

\begin{tabular}{|l|c|c|c|c|c|c|c|c|c|c|}
\cline { 2 - 13 } \multicolumn{1}{c|}{} & nöt & fär & häst & get & svin & höna & gås & bi & hund & kanin \\
\hline Finland & 3 & 3 & 1 & 1 & 1 & 1 & - & - & 3 & - \\
\hline Sverige & 6 & 3 & 3 & 2 & 1 & 6 & 2 & 1 & - & 1 \\
\hline Norge & 6 & 3 & 3 & 1 & - & 1 & 2 & 1 & 7 & - \\
\hline Danmark & 5 & 3 & 3 & 3 & 2 & 3 & - & 1 & 4 & 1 \\
\hline Island & 1 & 1 & 1 & 1 & - & 1 & - & - & 1 & - \\
\hline Grönland & - & - & - & - & - & - & - & - & 1 & - \\
\hline Făröarna & 1 & 1 & 1 & - & - & - & - & - & - & - \\
\hline
\end{tabular}

• utdód

Alla referenser är listade pa faktabladets hemsida: www.miljo.fi/nordensnatur > Faktablad $>$ Nordiska lantraser.

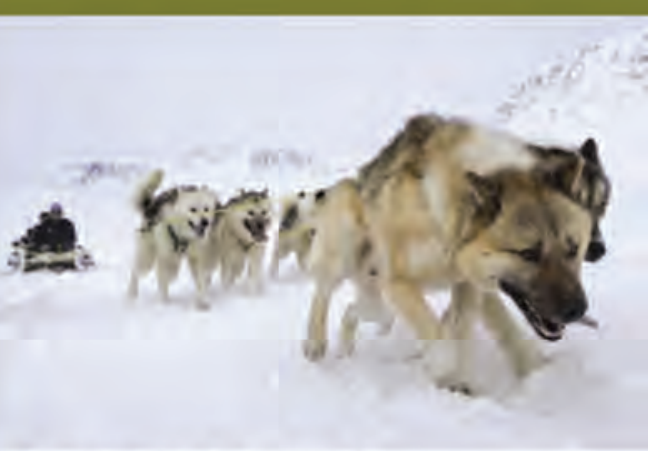

Grönländsk slädhund (Qimuttoq)

Den grönländska slädhunden har utvecklats ur vargen för tusentals àr sedan och kommit till Grönland med människan fràn văstra Sibirien. Hunden klarar av att ăta fruset kött och den är en nyttohund, inte en sällskapshund. För 10-15 àr sedan fanns det ännu 30000 slädhundar, men nu finns det bara 20000 . Antalet sjunker fortfarande, dels for att fodoanskaffningen har blivit svarare och en vuxen for att fodoanskaffningen har blivit svarare och en vuxen hund kan äta t.o.m. $400 \mathrm{~kg} \mathrm{kött} \mathrm{och} \mathrm{fisk} \mathrm{om} \mathrm{áret.} \mathrm{De/s}$ beror minskningen ocksà pá att motorkälkar har ersatt hundarna $i$ deras ursprungliga bruk. Man strävar efter att hälla rasen helt ren och korsningar med andra hundar tillàts inte. Slädhunden skyddas av lagen om slädhundar och om att halla hundar och katter. Det är förbjudet att hämte andre hunder till slädhundsomradet, som omfatter helattor andra tillätna hundarna är tjänstehundar, som enligt lagen màste vara steriliserade. Det är ocksá förbjudet att ta máste vara steriliserade. Det är ocksá förbjudet att ta
slädhundar till sydvästra Grönland. Bild: Carsten Egevang/ARC-PIC.COM

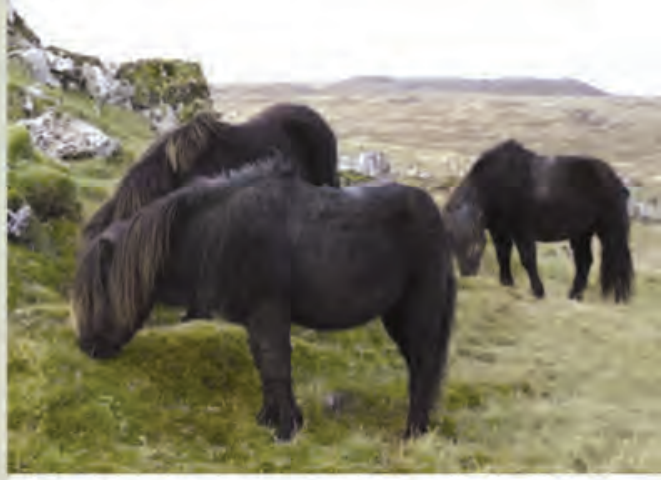

Färölsk ponny (Foerøerne)

Den färöiska ponnyn är en av de äldsta och renaste nuvarande hästraserma. Genetiskt är den närmast släkt med sydengelska och isländska hästar, och pàminner om de hăstar som hämtades till Europa fràn Asien c. 200 àr efter vàr tiderăknings börian. Ponnyn hämtades till Färöame av kelter och sk keller och skandinaver. Ponnyerna varmanga pa Farorna tills jordbruket moderniserades pa 1800-talet och arbetskraften övergick till fiskeindustrin. Den starka men lilla hästen var inte lämpad för att arbeta med plogar och andra verktyg, och jordbrukare valde att importera arbetshästar främst fràn Norge. Senare har hästar importerats ocksả fràn Island. Före den färöiska ponnyföreningen grundades fanns det bara fyra individer kvar av färöiska ponnym som till vintern fár en tjock päls. Den nuvarande ponnyn, som till vintern far en tjock pals. Den nuvarande Anna Louisa Joensen.

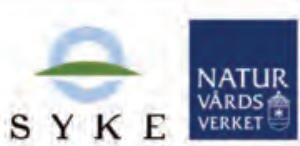

S Y K E
VARDS
VERKET

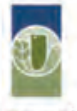

Diredcorate for
naturforvalining

\section{MILJØMINISTERIET}

By-og Landskabsstyreisen umhvorvisstovan
Grønlands Hjemmestyre
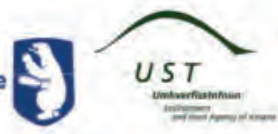


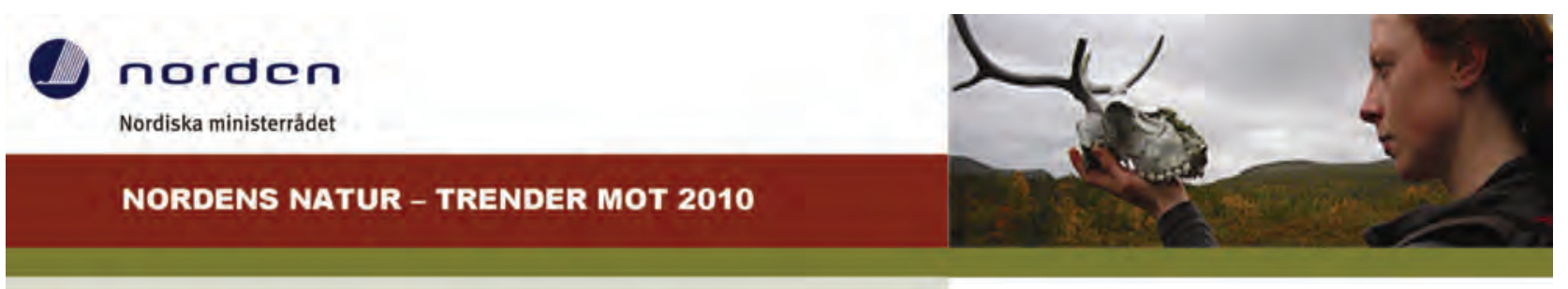

\section{Fåglar reagerar på klimatförändringen}

Jordens medeltemperatur steg i medeltal 0,74 celsiusgrader under áren 1906-2005. Ökningen var större i norr än annanstans och snabbare pả land än pá havet. Pá land har man kunnat konstatera att vảren blivit tidigare och växt- och djurarter förflyttat sig längre norrut och högre upp frản havsytan. Fàglarna är en välkänd djurgrupp, som reagerar snabbt pà temperaturändringar, vilket gör dem till goda bioindikatorer för klimatuppvärmningen.

Enligt resultat från undersökningar gjorda för den europeiska fågelatlasen kommer utbredningsområdena för făglar som häckar i Europa att förflyttas c. $550 \mathrm{~km}$ mot nordost och minska med en femtedel fram till slutet av seklet. Arterna kan antingen anpassa sig, förflytta sig till nya områden eller försvinna. Flyttavstảnden minskar och tiden som fáglarna stannar på sitt häckningsomrảde blir längre. I norr ökar antalet övervintrande fågelarter, och en del flyttfăglar kan bli stannfăglar eller delvis stannfåglar, som konstant följer med väder- och näringsförhållanden och vid behov fort kan utnyttja gynnsamma förhảllanden. T.ex. antalet övervintrande grönfinkar (Carduelis chloris) har ökat i Finland, medan antalet som flyttar till Tyskland över vintern samtidigt har minskat.

Enligt klimatmodeller kan flera arter försvinna från Norden. I Finland är det uppskattade antalet arter som försvinner över 20 , vilket är c. en tiondel av alla finska fảgelarter. Flera arter som nu häckar i hela Finland kommer i fortsättningen att häcka bara i norra Finland. Från Danmark uppskattas 35-40 arter försvinna under följande 80 år, men en motsvarade mängd nya arter förflyttar sig till Danmark för att häcka. Tyngdpunkten för artmångfalden i Europa kommer att förflyttas från Mellaneuropa till södra Finland och Baltiska länderna.

Det största hotet hänger över arktiska och alpina arter, så som ismås (Pagophila eburnea) och kärrsnäppa (Calidris alpina ssp. alpina). Dessa arter är beroende av habitat som minskar som en följd av klimatförändringen; den arktiska havsisen och palsamyrar smälter och tundran ändras till boreal skog. Arterna som försvinner ersätts av nya sydligare arter, men de arktiska och alpina arterna kan gå förlorade för evigt.

Enligt en ny finsk undersökning är speciellt de nordiska skogs-, kärr- och fjälarterna, t.ex. lappmes (Parus cinctus) och dvärgbeckasin (Lymnocryptes minimus), i fara att utrotas. De är just dessa arter som förlorar största delen av sitt habitat när klimatet blir varmare. Samtidigt hindrar Norra ishavet dem från att flytta längre norrut.

\section{Anpassning till förändrade förhăllanden}

Flyttfåglar följer en årstidsrytm och söker sig till de mest gynnsamma förhållandena enligt sin årliga cykel och försöker optimera tiden och platsen för att rugga, flytta och övervintra för att lyckas bra med förökningen. Eftersom fảglar är rörliga och egenvarma är det möjligt för dem att anpassa sig till det förändrade klimatet och samtidigt optimera de olika skedena i den árliga cykeln.

Tidig vår betyder också tidigare början på tillväxtperioden, tidigare insektförekomster, flyttfăglars ankomst, äggläggning och för många făgelarter bättre häckningsframgång. För att häckningen skall lyckas och ungama klara sig krävs också bra förhảllanden under försommaren. Klimatförändringen sägs vara osymmetrisk, vilket betyder att trots att vårtemperaturen har stigit, har temperaturen på försommaren inte stigit i motsvarande grad.

Näringssituationen både före under häckningen påverkar häckningsresultatet, och făglarna fảr problem om vảrflytten och häckningen inte blir tidigare i samma takt som tillväxtperioden och insekternas utveckling. Om flyttfåglarna inte kommer till häckningsområdet då näringsläget är optimalt lägger de färre ägg, eller i värsta fall inga alls.

\section{Stigande havsvattennivă hotar vadare}

Vadare (Charadnïdae) är allmänna häckande făglar, som det finns mer än 20 arter av i Norden. Många är långdistansflyttare som övervintrar söder om ekvatorn, som t.ex. kustsnäppan (Calidris canutus canutus), som flyttar två gånger årligen mellan Sibirien och Afrikas kuster över Finland och Norge. Förändringarna i kustsnäppans häckningsområden i den arktiska tundran, som orsakas av klimatförändringen är inte alltid bara negativa, men det är möjligt att ankomsttiden inte allid sammanfaller med de mest gynnsamma häckningsförhållandena.

Många vadare är beroende av grunda kustområden, som översvämningsslätter och marskland, där de äter och vilar under flyttningen eller övervintrar. Dessa kusthabitat är hotade av stigande havsvatten som orsakas av klimat-förändringen. I Vadehavet i Danmark, som är en viktigt rastplats för flyttande vadare, har vattenytan stigit $14 \mathrm{~cm}$ under de senaste 35 åren. Ytan förväntas fortsätta stiga $25 \mathrm{~cm}$ vart 50 . àr fram till 2100 , vilket betyder att marsklanden i Ostersjöområdet är allvarligt hotade.

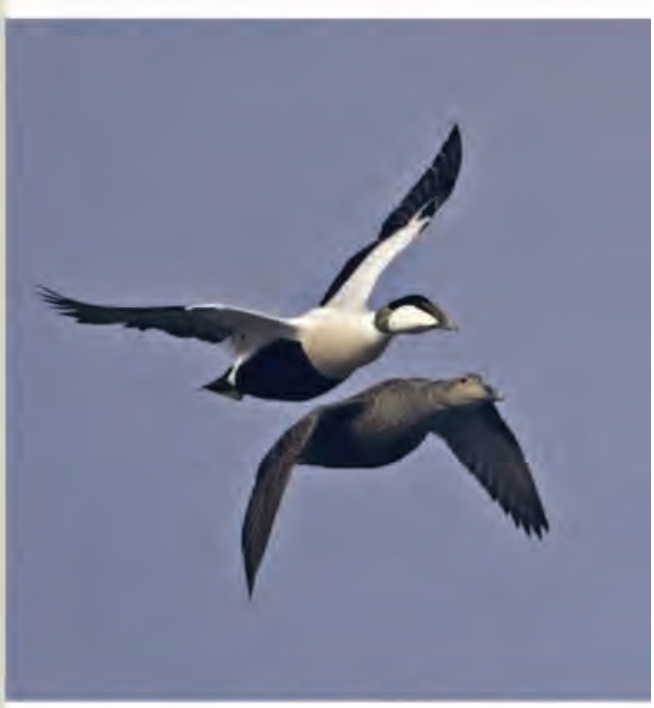

Enligt undersőkningar gjorda pà nordvästra Island kommer ejderns (Somateria mollissima) hackning att lida av extrema văderfơrhállanden, sả som blásiga och fuktiga vintrar, som förvăntas bli allt vanligare som en folljd av klimatförändringen. Bild: Jorma Tenovuo 
Klimatuppvărmningen kan orsaka konkurrens om resurser mellan stannfáglar och flyttfáglar, om skillnaden mellan deras häckningstider blir kortare och om beständen ökar. Det kan uppstá konkurrens om bohâlor om t. ex. talgoxen (Parus major), som är en stannfägel, och svartvita flugsnapparen (Ficedula hypoleuca), som flyttar ända frản Saharas södra sida, häckar samtidigt.

\section{Klimatförändringen màste bekämpas}

Uppvărmningen av klimatet máste bekämpas, för att inverkan pả de nordliga habitaten och fáglarna och ocksả andra arter skall kunna minimeras. Klimatuppvärmningen kan ha allvarliga följder för Nordens fäglar och deras häckningsomrảden och längs flyttrutterna. Det kan bli svàrare för fäglarna att hitta näring och det kan ocksả uppstả andra problem dả fảglarnas árliga cyke ändras och flytt- och häckningstider och näringsförhällanden varierar. Skyddsomráden màste grundas pả hăckningsomräden, ôvervintringsomräden och ställen längs med flyttrutterna där fáglarna stannar för att vila. Att bestànden är starka pà sina nuvarande utbredningsomràden màste ocksả försăkras.

\section{Orren - en stannfågel}

Hönsfäglarnas populationsväxling pàverkas starkt av klimatuppvärmningen. Hos flera arter har man kunnat konstatera att häckningen avviker frản den mest gynnsamma tidpunkten. Det sk. mismatching-fenomenet kan leda till populationsminskningar och till att den cykliska variationen i populationerna försvinner.

I en längtidsundersökning om orrens (Tetrao tetrix) spel i mellersta Finland har det kommit fram att spelet och därmed ocksá parningen och kläckningen har blivit tidigare under de senaste 40 áren pâ grund av att várarna har blivit varmare. Forsomrarna har ändă inte blivit varmare, vilket har lett till att ungarna kläcks under ogynnsamma förhällanden och ungdödligheten är hög. Ungarnas overlevnad har blivit sămre och populationerna har minskat. Ungproduktionen fortsătter att minska trots att dödligheten bland vuxna fáglar inte har ökat. Ungproduktionen máste săkras för att orren och andra hönsfáglar skall kunna bevaras.

Orren är ännu vanlig i Finland, Sverige och Norge, men den hotas förutom av klimatförändringen ocksả av ökande rovdjursbestánd. I Danmark dog orren ut för c. 10 ár sedan. Birdlife Finland förutspár att orren är en av de arter som kommer att försvinna frản sődra Finland som en följd av klimatförändringen.

\section{Bofinken - en närflyttare}

Bofinken (Fringilla coelebs) àr en närflyttande art, som overvintrar i Danmark och Mellaneuropa. Under senaste tiden har bofinkens ankomst till Norge, Sverige och Finland blivit tidigare som en följd av klimatuppvärmningen. Ankomsten har blivit c. 8 dagar tidigare under de senaste 20 åren, men det finns arter vars ankomst har tidigarelagts annnu mera. Bofinkens tidigare ankomst till Finland ár tydligare pả kusten än i inlandet. Tidigare ankomst betyder inte nödvăndigtvis tidigare hăckning.

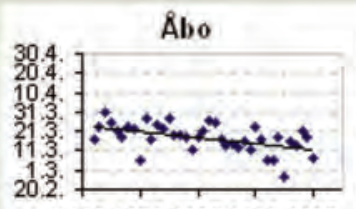

19651975198519952005

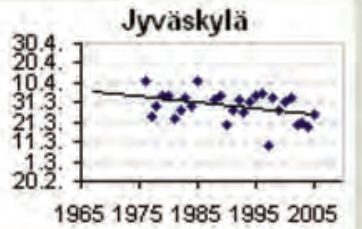

19651975198519952005
Tidigaste bofinksankomster $i$ Abo i sydvästra och Jyväskylä i mellersta Finland 1964 2007. Källa: Esa Lehikoinen, Abo universitet, fágelskaddarföreningars observationsdata.

\section{Svartvita flugsnapparen - en lángdistansflyttare}

I Norge har ett samband mellan vàrens temperatur och tidpunkten för vârens början och den svartvita flugsnapparens äggläggningstidpunkt upptäckts. I Norge har det under de senaste 10 àren förekommit varma vảrar, och under den tiden har häckningen blivit nágot tidigare. Insektföda har varit tillgänglig, sã svartvita flugsnappare har börjat häcka tidigare. De kan ocksả upptäcka vârens ankomst av vegetationens utveckling. Fäglarna strävar efter att häcka sả tidigt som möjligt, sả att ungarna skall ha tillrăckligt med tid att utvecklas före höstflytten.

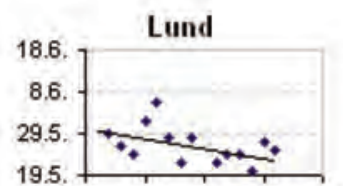

19901995200020052010

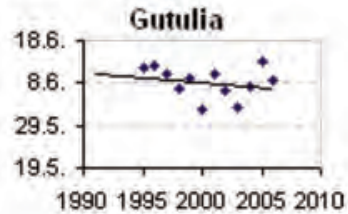

Svartvita flugsnapparens tidigarelagda äggläggning $i$ Lund i södra och Gutulia $i$ sydöstra Norge. Källa: Direktoratet for naturforvaltring.

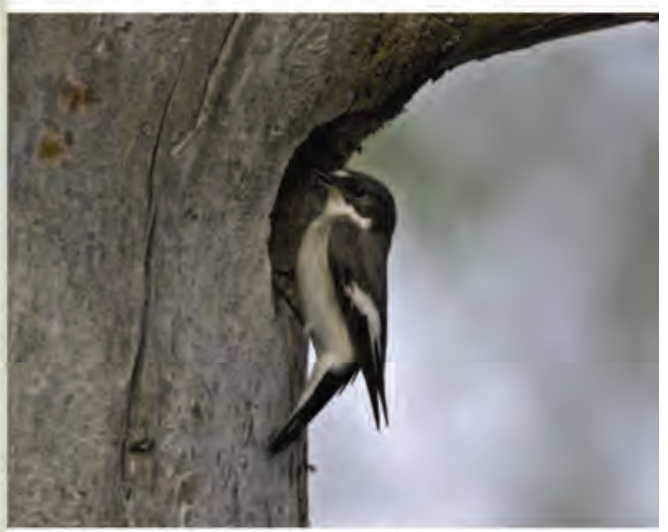

Svartvit flugsnappare. Bild: Jorma Tenovuo

Litteraturförteckning pá faktabladets hemsida www. miljo. fi/nordensnatur $>$ Faktablad $>$ Fäglar reagerar pá klimatförändringen

Finlands miljöcentral SYKE - www. miljo.fi/nordensnatur

\section{7 .2008}

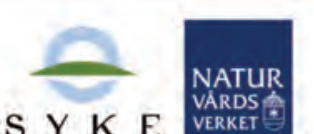

S Y K E

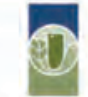
Diedcorate for
naturforvalining
……....

MILJØMINISTERIET

By-og Landskabsstyrelsen umhvorvisstovan
Grønlands Hjemmestyre
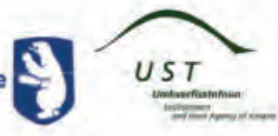


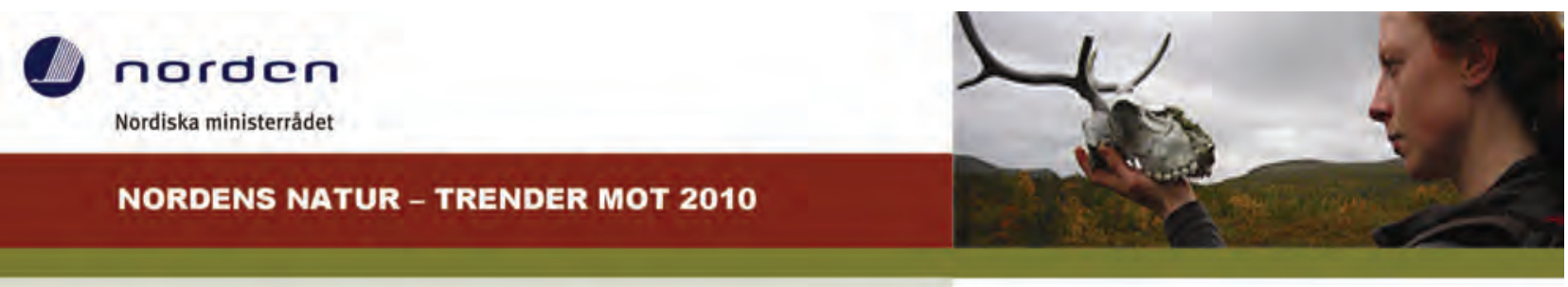

\section{Främmande arter i Norden}

Arter kan sprida sig frản ett ställe till ett annat naturligt, eller spridas avsiktlig eller oavsiktligt. Främmande arter är arter som med hjälp av människan har spridit sig utanför sitt naturliga utbredningsomráde. De kan bli skadliga, och kallas då invasiva, om de bőrjar konkurrera eller korsa sig med ursprungliga arter eller fånga dem. Inkomna arter kan ocksả sprida sjukdomar och ändra livsmiljöer. De erövrar plats av ursprungliga arter, dels för att de på nya områden saknar naturliga fiender. Främmande arter är det näst största hotet mot vår ursprungliga natur, efter fragmentering och förstöring av livsmiljöer. I Norden har 1357 främmande arter etablerat sig, varav många nu hotar mångfalden i vår natur.

Människan underlättar arters spridning över naturgeografiska spridningshinder som normalt skulle stoppa deras framfart. Frön, sporer, ägg och larver flyttas oavsiktligt till nya områden som fripassagerare i importerat virke, barlastvatten samt jord i samband med växttransporter. Problemen med främmande arter förvärras av ökande internationell handel, transporter och turism, som skapar nya spridningsvägar för växter och djur. De minst förutsägbara är sả kallade liftararter, som transporteras fästa vid bilar, tảg och fartyg, eller till och med $i$ resenärers skosulor. Också infrastrukturen, som människan byggt, så som kanaler, broar och tunnlar, hjälper arter att sprida sig. Klimatuppvärmningen kan underlätta spridning och etablering pă nya områden för många arter som tidigare har ansetts vara ofarliga.

Alla nya arter etablerar sig inte på nya områden, och alla blir inte heller invasiva. Enligt den så kallade tioregeln sprider sig en av tio inkomna arter till naturen, en av tio som spridit sig till naturen etablerar sig och en av tio etablerade arter blir invasiv. I Norden har t.ex. vresrosen (Rosa rugosa) som hotar våra ursprungliga växter, och minken (Mustela vison), som trängt undan flodillern (Mustela lutreola) blivit problematiska.

Också arter som införts avsiktligt kan sprida sig till nya områden, där de inte är önskade, som t.ex. bisamråttan (Ondatra zibethicus), som inplanterades i Finland i början av 1900-talet. Den har spridit sig frăn Finland till Sverige och till Norge, och orsakar nu ändringar $i$ vattendrag. Många prydnads- och odlingsväxter och djur som importerats som husdjur har rymt till naturen där de sprider sig aggressivt och konkurrerar med ursprungliga arter. Inhemska arter bör alltid föredras $i$ inplanteringar.

Oftast är vi oroliga över arter som kommer till oss, men arter som sprider sig från oss kan vara lika stora problem på nya omráden. Införsel av arter som kan vara invasiva måste hindras, men ocksả spridning från oss till andra ställen. Mera kunskap behövs om hur arter förlyttas och om hur de blir invasiva.

\section{Internationellt samarbete är preventivt arbete}

Bekämpning av invasiva främmande arter kräver hårt arbete, som avlägsnande av växter, utplåning av djur och kemisk bekämpning. Mycket har redan gjorts lokalt i de nordiska länderna, men ett stort arbete kvarstår ändå. För att hindra ankomsten av främmande arter finns t.ex. förpliktelser i internationella avtal. De är ändă inte fullt verkställda i alla länder, trots att det finns internationell lagstiftning, försäljningsförbud, olika tillståndsförfaranden och annan reglering av internationell handel samt gränskontroller och begränsningar för tömning av fartygens barlastvatten i havet. Utan övervakning saknar förpliktelser och regler verkan.

Försiktighetsprincipen borde alltid tillämpas, dvs. inget borde importeras om man inte känner till eventuella följder. Risker borde alltid uppskattas i förväg, men om skadan redan är skedd borde man kunna tillämpa förorsakarprincipen En uppskattning av skadornas ekonomiska värde skulle antagligen sätta fart på bekämpningen.
NOBANIS-projektet - ett nordiskt initiativ för att sprida kunskap om främmande arter

Ar 2004 började uppbyggandet av en databas om främmande arter som ett nordiskt samarbetsprojekt. Databasen upprătthälls och uppdateras regelbundet av medlemsländerna. Databasen inneháller ocksà icke-invasiva arter, som mójligen i framtiden kan bli invasiva. Numera omfattar samarbetet förutom Norden ocksà största delen av Nord- och Mellaneuropa. Databasen erbjuder information om främmande arters ankomst, spridning, potentiella frammande arters ankomst, spridning, potentiella verkningar. Den utgör därmed grunden för ett verkningar. Den utgör därmed grunden for ett
varningssystem för invasiva frămmande arter. varningssystem för invasiva frămmande arter.
NOBANIS-projektet publicerar ocksả faktablad om främmande arter. www.nobanis.org

\section{Jätteflokorna (Heracleum sp.)}

Jätteflokorna är avsiktligt införda som prydnadsväxter och har bildat enorma bestånd $\mathrm{i}$ Norden, speciellt i Norge. Den naturliga vegetationen på havsstränder och i vägrenar täcks av de enorma växterna, som också kallas Tromsös palmer. Jätteflokorna är också skadliga för människan, eftersom deras växtsaft orsakar kraftiga hudreaktioner. Flokorna kan bekämpas kemiskt och mekaniskt, men de är svåra att utrota, eftersom det inte räcker med att avlägsna dem en gång. Växtema bildar en långlivad fröbank i jordmånen, och förnyar sig effektivt från fröna. Uttrotningen av de nuvarande bestånden kräver hårt arbete, och effektiv bekämpning förutsätter att vidare spridning hindras med hjälp av information. I Danmark har myndigheterna till och med rättighet att bekämpa jätteflokor på privat mark.

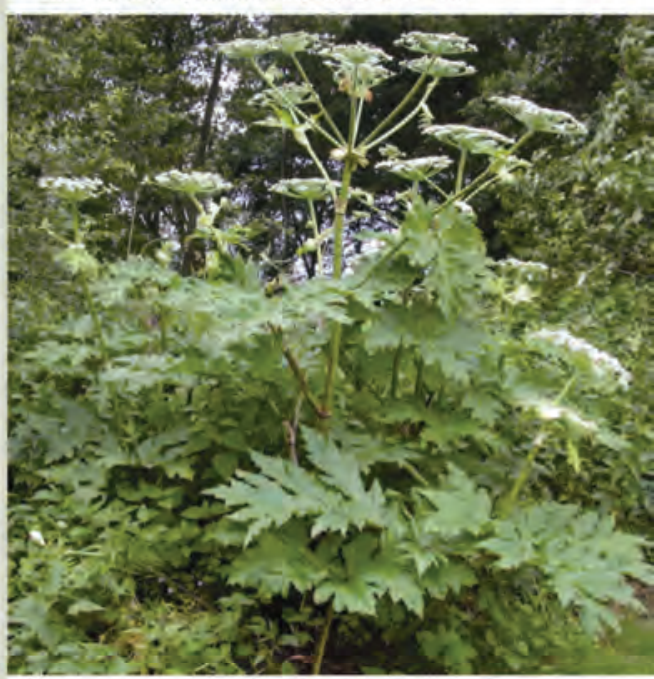

Bild: Harry Helmisaari 
Det finns ett behov för internationella förhállningsregler och linjedragningar om hur man skall ta itu med främmande arter. I arbetet ingăr utformandet av nationella strategier och handlingsprogram, där bland annat myndigheternas ansvarsfördelning definieras. Samarbete om främmande arter är viktigt i Norden, eftersom förhállandena är liknande och mảnga främmande arter är gemensamma och orsakar samma problem i stora delar av Norden. I alla nordiska länder behövs mera finansiering och forskning om främmande arters ekologiska och ekonomiska verkan.

\section{Information är viktigt i bekämpningen}

Informationsförmedling är centralt då man försöker hindra spridningen av främmande arter. Kunskap, kunskapsutbyte och informationen àt medborgama máste ökas, eftersom spridningen av främmande arter ofta beror pâ brist pá kunskap. Medborgarna behöver veta vad sprindningen av främmande arter kan ástadkomma i vảr natur, som t.ex. att vresrosen sả smàningom övertar vảra sandstränder, vilket är ett problem speciellt i Danmark. Information är nödvăndigt, eftersom bekämpningen ăr utan verkan och arbetet oăndligt om inte ny spridning hindras samtidigt som redan existerande bestånd bekämpas.

Problem med bekämpning och spridning av information gäller $i$ allmänhet inte arter som orsakar direkt ekonomisk skada, antingen genom direkta skador eller genom att kräva kostsam bekämpning. Sảdana arter är t.ex. koloradobaggen (Leptinotarsa decemlineata), som skadar potatis och tallvedsnematoden (Bursaphelenchus xylophilus), som förstör tallskogar, och i framtiden kanske kammaneten (Mnemiopsis leidyi). Dessa bekämpas i större utsträckning än söta och vackra arter, som tex. de vilda kaninerna som förökat sig vảldsamt i Helsingfors under de senaste ăren, eller blomsterlupinen som spridit sig längs vägrenar $\mathrm{i}$ Norden.

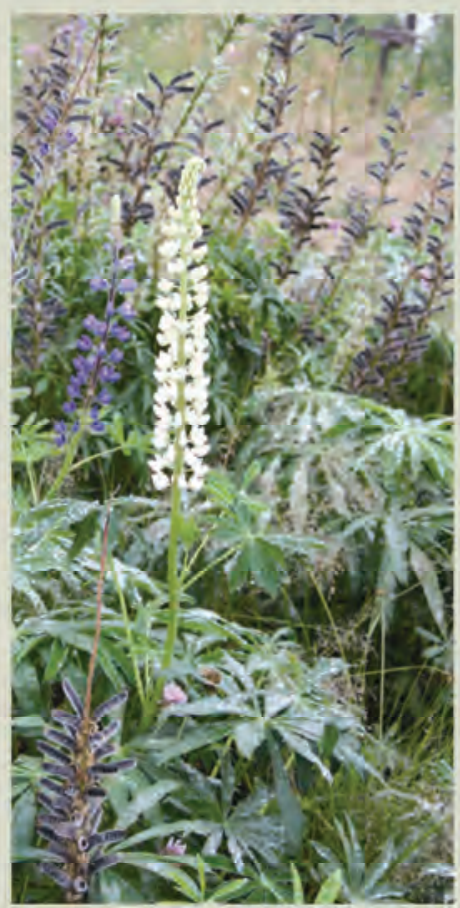

Blomsterlupin och sandlupin (Lupinus polyphyllus, L. nootkatensis)

Lupiner har införts avsiktligt som prydnadsväxter. Blomsterlupinen och sandlupinen, som sprider sig effektivare än andra lupiner, sprids frản trädgårdar med trä́dgårdsavfall och har till och med sảtts avsiktligt i vägrenar. De binder kväve från luften och gör pá sá sătt jordmánen ogynnsam för naturliga arter och tränger undan dem. Lupiner gãr att bekämpa, t.ex. genom slătter före frösättning Pá Island infördes sandlupin för at hindra erosion och för att förbättra jordmánen pá skräpmark. Lupinen sprider sig effektivt speciellt pá omráden där fár inte betar. Strävan att hindra vidare spridning av sandlupinen ingár i Islands naturskyddslag och dessutom finns speciella lupinbestämmelser. Pá Färöarna har lupinen, som hämtats frán Island, hällit sig $i$ trädgårdar, möjligen tack vare effektivt färbete.

\section{Spansk skogssnigel (Arion lusitanicus)}

Spanska skogssnigeln är en nykomling i Norden. Snigeln hittades först i Sverige ár 1975. Nu finns den i alla nordiska länder. Den äter nästan vad som helst, till och med rabarberblad som inte duger àt andra snigelarter.

I Sverige har spanska skogssnigeln inte ännu orsakat ekonomiska förluster, som i mảnga mellaneuropeiska länder och t.ex. pả jordgubbsodlingar i Norge. Den orsakar stor skada i trädgårdar och dess snabba framfart samt övervintring ger orsak till oro över kraftig ökning i Norden. speciellt dả inget naturligt förekommande djur jagar den.

Spanska skogssnigeln trivs och förökar sig effektivt i fuktiga förhällanden och unga individer klarar av milda vintrar. Arten är tvăkönad och kan föröka sig redan om en individ övervintrar. Den sprids passivt av människan, eftersom ägg och unga individer kan förflyttas lánga sträckor med växters mull och kortare sträckor med trädgårdsavfall. Självständigt kan arten förflytta sig bara relativt korta sträckor. Kommersiella trädgàrdar och privatpersoner bär ett stort ansvar för snigelns spridning.

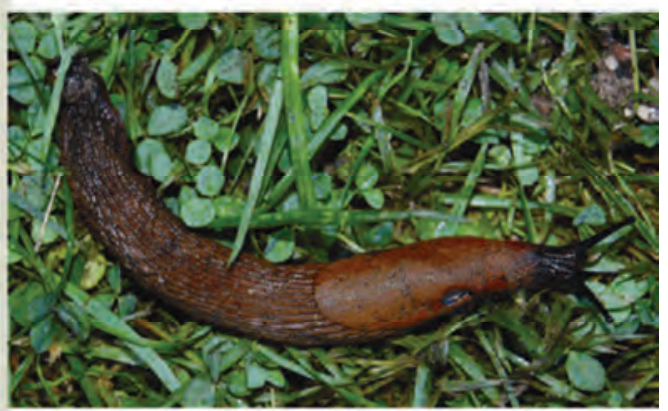

Bild: Anna Maria Hill Mikke/sen

Antal främmande arter som etablerat sig i Norden

\begin{tabular}{|l|r|}
\hline I havet & 46 \\
\hline I sötvatten & 52 \\
\hline På land & 1259 \\
\hline Sammanlagt & 1357 \\
\hline
\end{tabular}

Källa: Weidema, I. R. (red.). 2000. Introduced Species in the Nordic Countries. Nord 2000:13. Nordiska ministerrådet, Köpenhamn.

Litteraturförteckningen finns pả faktabladets hemsida: www, miljo.fi/nordensnatur $>$ Faktablad $>$ Främmande arter

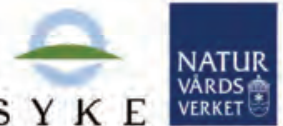

$S Y K E$

VARDS
VERKET:

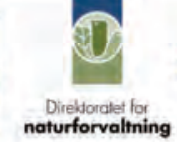

MILJø̈

\section{MINISTERIET}

By-og Landskabsstyrelsen umhvorvisstovan Hjemmestyre

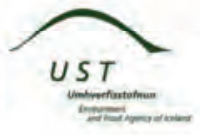




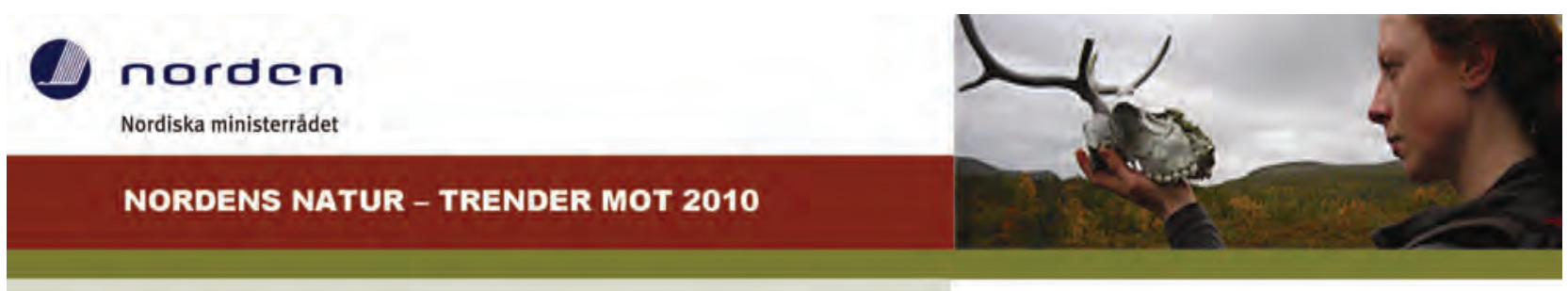

\section{Kan Nordens groddjur räddas?}

\section{Alarmerande tal under grodans àr 2008}

Âr 2008 har internationellt utsetts till grodans år, för att påminna om att minst en tredjedel av världens 6000 groddjursarter är utrotningshotade enligt Världens naturskyddsförbund IUCN. Populationerna av hälften av arterna minskar ständigt och betydliga utdöenden har bevittnats sedan 1970-talet. 165 groddjursarter antas redan ha dött ut $i$ världen. Grodomas globala utdöende är alarmerande ocksả för människan, eftersom många arters hud utsőndrar ämnen som är viktiga råvaror för mediciner. Nya möjligheter upptäcks fortfarande och just nu utvecklas t.ex. en ny medicin mot HIV.

Hälften av groddjursarterna i Europa befaras försvinna före år 2050. Också de nordiska bestånden har gått tillbaka betydligt, men situationen är inte fullt så allvarlig som globalt. Fem av Nordens 15 groddjursarter är utrotningshotade i minst ett nordiskt land, och fyra arter är missgynnade. I Sverige är den grönfläckiga paddan (Bufo viridis) akut hotad, liksom gölgrodan (Rana lessonae) i Norge.

\section{Sjukdomar och förändringar i livsmiljön utgör de största} hoten

Groddjuren hotas av fragmentering och förstöring av livsmiljöer. Dammar och våtmarker försvinner dả de torkas, dikas, uttylls eller bebyggs. Som följd av fragmentering blir avstảnden mellan dammarna för långa, och groddjuren kan inte sprida sig. Då minskar genutbytet mellan populationerna och smá populationer kan krympa ytterligare eller till och med försvinna.

Dammar och våtmarker som lämpar sig för grodornas lek kan lätt eutrofieras, växa igen eller försuras som följd av mänsklig aktivitet. För att vattnet skall värmas upp måste dammarna hảllas öppna och soliga. Försurning stör grodornas lek. Dammarna kan också förstöras av pesticider och gödsel från jordbruk. Grodomas förökning hotas dessutom av inplanterade fiskar och krăftor, som äter grodrom och yngel.

De nyaste hoten mot groddjuren i Norden är sjukdomar. I Slagelse kommun i Danmark hittades nyligen 1200 döda ätliga grodor (Rana esculenta) i en enda damm. Det är ännu oklart hur ranaviruset som orsakade grodornas död har kommit till Danmark. Viruset förekommer annars bara i Asien, Australien, Italien och södra England.

Största orsaken till de kraftiga populationsminskningarna hos groddjuren sedan 1970-talet antas vara svampsjukdomen chytridiomycosis, som orsakas av parasitsvampen Batrachochytrium dendrobatidis. Svampen gör att grodornas hud sväller upp och hårdnar. Då hålls huden inte fuktig och hudandningen försvåras. Sjukdomen är påträffad på alla kontinenter förutom Asien. I Danmark förekommer den hos två grodarter, vanlig groda (Rana temporaria) och ätlig groda, men har tillsvidare inte påträffats i något annat nordiskt land.

Åndringar i klimatet påverkar groddjurens förökningstidpunkt. Tidig lek under varma vårar kan förstöras av kalla perioder senare på våren, och torka blir ett problem efter snöfattiga vintrar, dả det är ont om smälttvatten. Klimatuppvärmningen leder också till att dammarna vărms upp, torkar och blir grundare, och dả tränger UV-strålningen lăttare igenom vattnet. UV-strảlningen orsakar mutationer och förökningsproblem hos groddjur.

Under milda vintrar förbrukar paddor (Bufo bufo) mera energi i dvala eller partiell dvala än under kalla vintrar. Som följd av detta har honoma konstaterats vara mindre och i sämre kondition efter milda vintrar, och då lägger de färre och mindre ăgg. Dålig kondition gör dem ocksả mottagligare för sjukdomar, vilket försvàrar förökningen ytterligare.

\section{Groddjur}

Groddjuren (Amphibia) ăr en klass inom ryggradsdjuren. Groddjuren är văxelvarma och som vuxna halvt vattenlevande. I deras utveckling ingár ocksa ett helt vattenlevande larvstadium, da de andas med gălar. Ocksá det vetenskapliga namnet Amphibia syftar till dubbelt liv, dvs. liv bàde i vatten och pá land. I havsvatten finns dock inga groddjur. Till groddjuren hör stjärtlösa groddjur (grodor och paddor), stjärtgroddjur (salamandrar) samt maskgroddjur. De har en viktig roll $i$ ekosystemen, eftersom de âr bàde bytesdjur och predatorer. Groddjur fangas av bland annat ormar, mànga dăggdjur och fáglar. I Norden förekommer nio grodarter, tre paddarter och tre salamanderarter.

\section{Lövgrodan inte längre utrotningshotad i Danmark}

Pă Själland fanns pă 1980-talet bara en handfull lövgrodor (Hyla arborea) kvar. Efter năgra misslyckade försök lyckades man äntligen plantera in lövgrodor i 60 nygrävda och restaurerade dammar på västra Själland. Nu uppgår populationen till över 1000 lövgrodor, som sprider sig effektivt. Också på Bornholm, där arten för 15 ảr sedan var hotad har lövgrodan àterhämtat sig som följd av restaurering av dess livsmiljöer. Åtgärderna för att rädda lövgrodan har varit framgångsrika, och arten är inte längre utrotningshotad i Danmark.

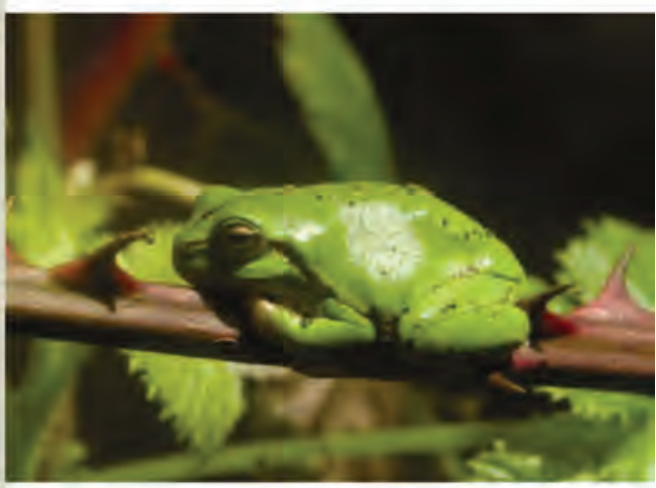

Aven i Sverige har arbetet med lövgrodan varit framgángsrikt. Populationen i Skáne har pá 20 ár mer ân fyrdubblats till over 10000 spelande hanar tack vare restaurering av smàvatten. Lövgrodor finns nu pá över 800 platser i Skàne. Bild: Niels Sloth 
Utoover ovannämnda hoten blir ett stort antal grodor överkörda árligen, dả de rör sig över văgar i sin allt mera splittrade livsmiljö.

\section{Upp till kamp för groddjuren}

I Finland, Sverige, Norge och Danmark âr alla groddjur fridlysta. Utgàngspunkten för groddjursskydd arr att skydda deras livsmiljöer. Det mảste finnas dammar, vătmarker och fuktiga övervintringsställen för groddjuren. I Danmark är alla dammar över $100 \mathrm{~m}^{2}$ skyddade som livsmiljöer för groddjur, och i sődra Finland ăr det förbjudet att anndra naturtillstảndet $i$ dammar under en hektar, och smả dammars näromgivning máste skötas sá att särdragen bevaras. Dammarna kan förbăttras genom restaurering och man kan ocksả grăva nya dammar. Pà sả sătt säkras de redan existerande bestảndens fortbestảnd samtidigt som populationernas tillväxt möjliggörs. Det är ocksả bra att grăva djupare sănkor i dammarna, som ger skydd at grodorna under torra somrar och ocksâ skyddar mot UV-strälning.

Klimatförändringen har en betydande roll i skyddet av groddjur, eftersom den ocksả förvärrar många av de problem som inte är direkt orsakade av den. Dammarna torkar lattare om somrarna blir varmare, och chytridiomycosis sprids effektivare om temperaturen och fuktigheten blir gynnsamma för den. Klimatförändringen kan tillintetgöra annars bra skyddsătgärder, om de inte anpassas till kraven som ställs av klimatförändringen.

Trots att groddjurens situation är orovăckande, är det tröstande att se att lokala ătgärder i Norden, sả som inplanteringar och restaurering av livsmiljöer har varit framganngsrika och bidragit till att groddjurens levnadsvillkor har förbättrats.

\section{Nya dammar àt gölgrodan i Norge}

Gölgrodan (Rana lessonae) upptácktes som en ny art i Norge âr 1986, men dess uppföljning började först tio ár senare. Arten hade en liten lokal population i tre dammar i Aust-Agder lăn. Populationens storlek varierade mellan 15-50 förökande vuxna individer, beroende pá vinterns kyla. En handlingsplan för skyddet av den akut hotade gölgrodan gjordes àr 2006.

I Aust-Agder böriade man genast verkställa handlingsplanen. Fisk, som âter rom och yngel, avlägsnades frán dammar och nya fiskar hindrades frán att komma till dem. Nya dammar grävdes ocksâ, och skuggande träd fälldes. Bara tvà àr senare fanns grodor redan i fyra av fem nya dammar. Pá sommaren 2009 blir det klart om grodorna ocksả börjar leka i de nya dammarna. I fortsăttningen grävs ännu flera nya dammar $i$ omrădet, för att garantera att nătverket av dammar âr tillräckligt tătt.

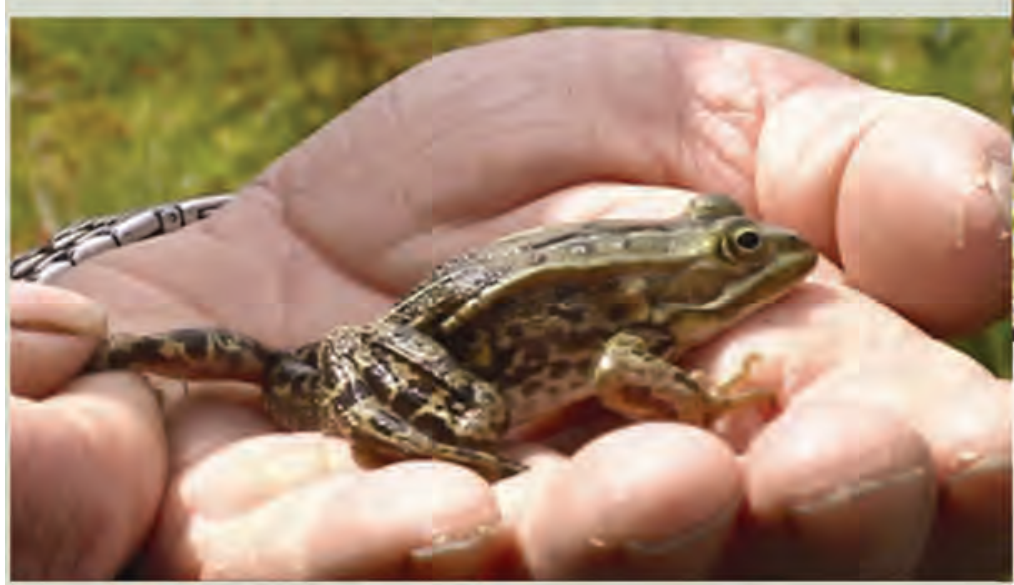

Gölgroda. Bild: Svein Nic. Nordberg

\section{Större vattensalamandern skyddas}

Större vattensalamandern (Triturus cristatus) hotas liksom andra groddjur av ändringar i livsmiljön. Dammarna minskar i antal och deras tillstảnd försämras, och livsmiljöerna fragmenteras. Arten är klassificerad som sårbar i Finland och Norge. I Sverige bedôms arten vara livskraftig, men inventeringar àr 2005 pávisade tillbakagâng. Både Sverige och Norge har átgärdsprogram för skydd av större vattensalamandern. I Finland är större vattensalamandern tillsvidare den enda groddjursarten som har gett upphov till konkreta skyddsătgärder, och en skyddsplan för arten utarbetas som bäst.

Dammar har restaurerats, och nya dammar grävts för att skydda större vattensalamandern. Fisk har avlägsnats frân dammar, eftersom de äter salamanderns rom och yngel. Dammarnas stränder är ocksá viktiga som viloplatser och övervintringsställen för salamandern, och därför fảr de inte röjas för kraftigt, sả att de blir för öpnna. Lövträd borde föredras i närheten av dammarna och fisk fâr inte planteras ut $i$ dammar där det inte finns fisk frản förut. Det är ocksả viktigt att markägarna känner till större vattensalamanderns förekomst, sâ att de kan beakta den, eftersom redan smá åtgärder kan ha en stor betydelse för arten.

Finland, Estland och Danmark samarbetar om skydd av större vattensalamander i ett EU Lifeprojekt (2004-2008). Projektets mál är att garantera gynnsamma förhállanden för större vattensalamandern för att populationen skall hảllas livskraftig. Samarbete med markägare och skogsvårdsföreningar, samt informering om arten och dess ekologi är en stor del av projektet.

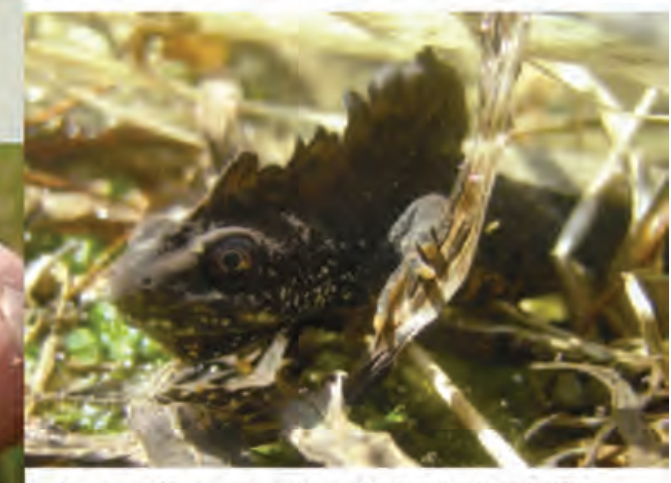

Hane av större vattensalamander i lekdrákt. Bild: Ville Vuorio

Litteraturförteckning pả faktabladets hemsida www.miljo.fi/nordensnatur $>$ Faktablad $>$ Nordens groddjur

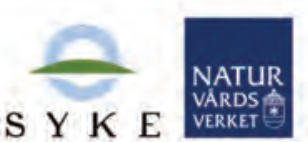

S Y K E

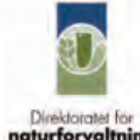

naturforvalialining

\section{MILJØMINISTERIET}

By-og Landskabsstyrelsen umhvorvisstovan
Grønlands Hjemmestyr
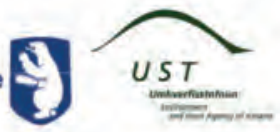


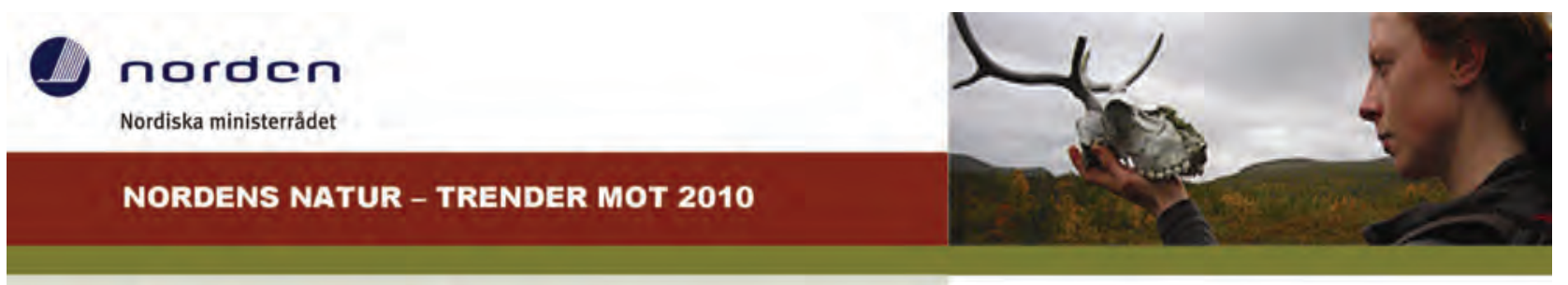

\section{Mot hållbart bruk av ren- och fårbetesmarker i Norden}

Ren- och fárbete kan ha bảde negativ och positiv inverkan pả biologiska mảngfalden. Inverkan beror pà vilket djur som betar, djurens antal, naturtypen som betas samt dess produktionsförmága. Ocksả ảrstiden och betets intensitet har betydelse.

Betande renar och făr påverkar betesmarkerna i området de betar på många sätt. För kraftigt bete kan ändra växtartsammansättningen och skada vegetationen som till och med kan försvinna helt, vilket skadar jordmånen och kan leda till erosion. $\AA$ andra sidan kan mảngfalden pả vissa omráden gynnas av lämpligt bete, som hindrar igenväxning. I Norden bör man därför ännu tydligare sträva efter ett långsiktigt hållbart bruk av ren- och fårbetesmarkerna för att gynna biologiska mångfalden samt att olika näringar och markanvändningsformer är förenliga med varandra.

\section{Renbetets inverkan på vegetationen}

Som följd av kraftigt bete blir vegetationen ensidigare och artmångfalden minskar. $\AA$ andra sidan växer områden igen i avsaknad av bete. I båda fallen minskar naturbetesmarkernas, och därmed hela Nordens biologiska mångfald. En växling mellan perioder av kraftigt och svagt bete skapar däremot bra förutsättningar för till exempel krävande kärlväxter, förutsatt att betesintensiva perioder inte blir för långvariga. Fiällbiotoperna är särskilt känsliga för hårt bete på grund av samverkande faktorer sásom kärva klimatförhảllanden, lảngsamma jordmånsprocesser, tunna jordlager, kraftig vind- och vattenerosion, vegetationens låga produktionsförmåga samt markens ibland kraftiga lutning.

På vintern betar renarna i första hand lättsmälta lavar, tagellavar, gräs och ris, och på sommaren örter och löv. Kraftigt bete leder till att mindre smakliga och svårsmälta örter, gräs, starr och mossor ökar. Om renarna inte kan förflytta sig till nya betesområden betar de även dessa växter och då kan helt vegetationslösa områden uppstå, som är känsliga för erosion. Lavbetesmarkerna behöver en lång tid för att áterhämta sig efter att betestrycket minskar, men andra betesmarker áterhämtar sig $\mathrm{i}$ allmänhet relativt snabbt.

Tidigare begränsades renarnas antal i första hand av vinterbetesmarkernas bärkraft och väderförhållanden. Om renarna pả vintern inte kommer ăt födan

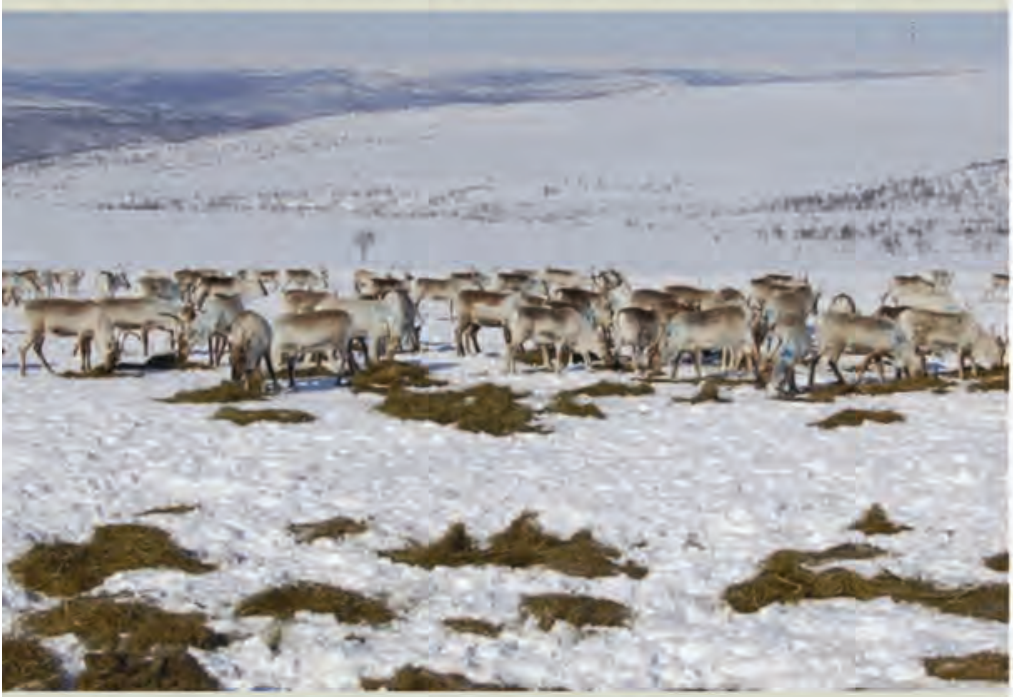

I Finland făr renarna tilläggsfoder pà vintern. Bild: Mauri Nieminen

\section{Renar och fár i Norden}

Renar har hört till Nordens natur $i$ över 10000 àr, ända sedan istidens slut. I norra Skandinavien och norra Finland har renskőtsel med tamrenar förekommit ända sedan 800 -talet, och pá 1600-talet utvecklades renskötseln till en betydande näring I Norden betar renarna i fjăll- och skogsomráden i norra delarna av Norge, Sverige och Finland.

Fărskötsel förekommer $\mathrm{i}$ alla nordiska länder, men färbete orsakar betydande problem bara pá Färöarna, Island och Grönland. Vikingarna hămtade fáren till dessa öar redan pá 800-900-talen.

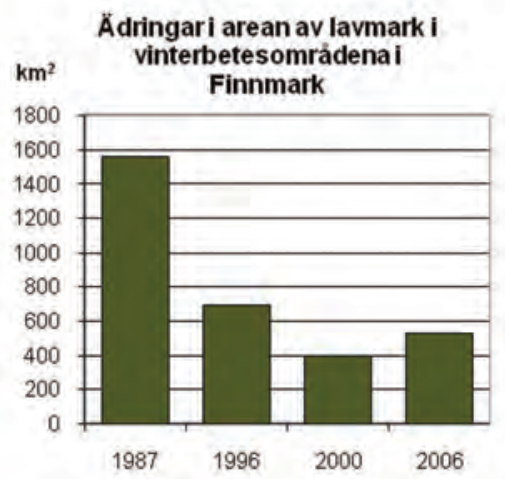

Lavmarkerna i Finnmark har okat lite under 2000-talet Kalla: Norut As

I norska Finnmark är renhjordarna täta. På sommaren betar djuren pá kusten och på vintern på inlandets fjällhedar. Vinterbetesmarkerna i Finnmark var i gott skick ända till 1980talet, men har sedermera blivit starkt överbetade. Renantalet sjönk under renskötselåret $2000 / 2001$, men har sedan dess stigit igen. Samtidigt har också lavbetesmarkernas area ökat från år 2000 till 2006, då den senaste satellitkarteringen gjordes. Ökningen möjliggjordes av senaste årens snöfattiga vintrar. Dả det finns mycket snö är sänkorna mellan fjällviddens högre partier täckta av ett tjockt lager snö. och de högre partierna, som hálls snöfattiga av vinden, blir lätt överbetade. Under snöfattiga vintrar kan renarna däremot beta också i sänkorna och då lättar betestrycket på de högre partierna. 
genom snön lider de av năringsbrist. Numera får renarna i Finland tilläggsfoder i form av ensilage och hö på vintern. Vinterutfodringen, samt medicinering av djuren mot parasiter, har på många håll gjort det möjligt att hålla större renhjordar än betesmarkema naturligt kan upprätthålla. Som följd av detta, och av att människan begränsar renarnas rörelse med stängsel, har det uppstått lokalt overbete.

Eutrofa områden lider av sommartida bete och trampande, vilket hotar fjallbjörk- och videdungama om de inte kan förnyas. Sommarbetet sliter också växttäcket på karga lavhedar och kalfiall, speciellt vid renstängslen. På vinterbetesmarkerna skadar renarna lavtäcket bara fläckvis, då de gräver fram lavarna genom snön.

I Finland tăcker renskötselområdet en tredjedel av landets yta. Fjällområdet ăr ställvis kraftigt betat både på sommaren och på vintern. Intensivt bete på samma områden året runt minskar lavarna, som förnyas långsamt, trots att renama på sommaren främst äter löv och örter. Lavtäcket på sommarbetesmarkerna är ândå på grund av sommartida trampande i betydligt sămre skick än på vinterbetesmarkerna. De sköra lavama trampas lătt sönder då ingen snő skyddar dem. I Finland har lavtăcket försämrats redan länge. Lavarna fömyar sig bra bara på några få ställen i allra nordligaste Finland. I övriga områden är lavarna antingen kraftigt slitna eller förnyas långsamt.

Under 1990-talet uppmärksammades flera fall av vegetationsskador och jorderosion i de svenska fjällen. Senare forskning har dock visat att de kraftiga tramp- och betesskador som ibland förekommer vid inhägnader och stängsel inte är allmänna i hela fjällkedjan. Situationen i de svenska fjällen är inte jämförbar med de situationer som uppstått till följd av alltför intensiv rennäring i norra Finland och i norska Finnmark.

\section{Fàrens inverkan på Nordatlantens öar}

På Färöarna överskrider fårbetet områdets bärkraft i nuvarande klimat. Färöarna ligger innanför den nordliga trädgränsen och utan det kraftiga fårbetet kunde vide văxa på ỏarna. Idag finns c. 70000 fullvuxna får på Făröarna. Det finns c. två hektar betesmark per får, vilket nătt och jämnt överskrider gränsen för överbete. På sommaren betar fåren på naturbetesmarker och på vintern också på åkrar och gräsmattor i tătorterna.

I värsta fall kan kraftigt bete och văderförhållanden leda till att vegetationen försvinner och jordmånen eroderas. Island och Grönland har samma problem som Färöarna med kraftigt bete och slitage av vegetationen som leder till erosion. På Färöarna följs betets inverkan på erosionen upp på öarna Streymoy och Sandoy, dăr betesmarker ăr inhägnade.

På Island betar făren fritt i landskapet under somrama. Under senare tid har effekten av betet på erosionen varit mindre än tidigare, vilket beror på att antalet får har minskat till hälften under de senaste 30 åren. En annan orsak är t.ex. understöd som beviljas för hållbart bruk av betesmarker. Cirka $40 \%$ av Islands yta ăr allvarligt eroderat. Dessutom har en svag erosion börjat på $26 \%$ av ytan. Utvecklingen på de svagt eroderade områdena går ännu att vănda genom att se över markanvändningen eller genom åtgärder för att öka vegetationen. Det är svårt att avgöra i vilken grad erosionen beror på tidigare utbrett överbete, men numera har naturens krafter såsom vind och vatten den största betydelsen. Bete inverkar fortfarande lokalt på erosionen, men i allt mindre grad jämfört med de primära orsakerna. Numera betar knappt 500000 får och 70000 hăstar på Island.

På södra Grönland började kommersiell fårskötsel i början av 1900-talet, med djur hämtade från Fărbarna och Island. I 50 års tid betade făren i fjällen året runt, och antalet får varierade kraftigt på grund av brist på foder och stall samt ogynnsamma väderförhållanden. Dagens fårskötsel grundar sig på hållbart bete och fåren betar fritt bara på sommaren. På vintern hålls de i stall. Numera finns c. 20000 fullvuxna får på Grönland. Trots att överbete förekommer lokalt finns det enligt uppskattningar plats för lika många får till på sődra Grönland.

Litteraturförteckningen finns pả faktabladets hemsida: www.miljo.fi/nordensnatur > Faktablad $>$ Ren- och fárbete

\section{Förutsättningar för hållbart bete}

För den biologiska mångfaldens del är ett hållbart bruk av naturresurserna en grundförutsättning. Antalet betande djur måste băttre anpassas till betesmarkernas produktions- och förnyelsefömmåga så att den biologiska mångfalden och produktiviteten kan upprătthållas. För att förbättra betesmarkerna och öka mångfalden borde cirkulerande bete utvecklas och bete styras till tåligare områden och områden som hotar växa igen. Om klimatförändringen fortsătter och betet inte hålls måttligt och lämpligt för varje område kan fjallinaturtyperna ändras ännu mera både till sin artmångfald och vegetationens riklighet.

Renskötsel hör till de nordliga folkens äldsta traditionella näringar, som bör bevaras också för sitt kulturhistoriska värde. Får- och renskötseln måste vara förenliga med andra näringar och markanvăndningsformer, inklusive naturskyddet. Reglering av antalet renar och får ăr ändå en svår fråga, eftersom ren- och fårskötsel år viktiga näringar. Samhăllet måste kunna erbjuda alternativ om dessa näringar måste begränsas.

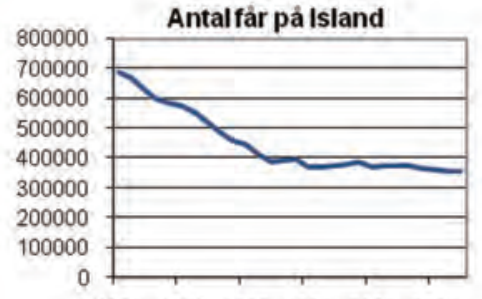

$1980 \quad 1985 \quad 1990 \quad 1995 \quad 20002005$

Antalet fär pà Island har halverats under de senaste 30 áren. Källa: Islands statistikcentral

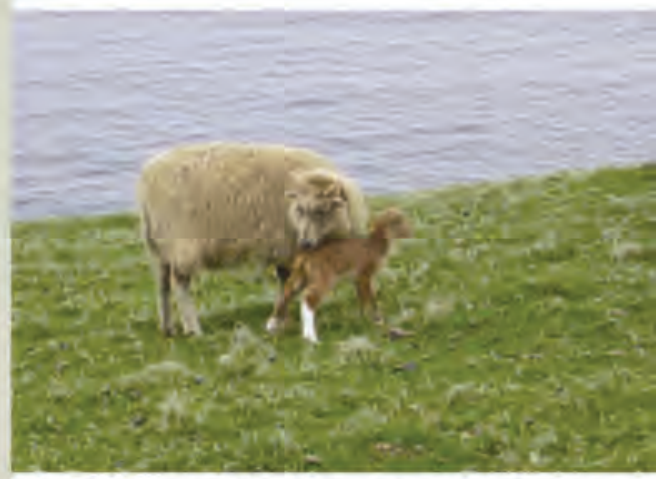

Pá Färóarna betar fáren fritt i landskapet. Bild: Anne Maria Fosaa

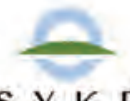

S Y K E

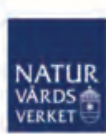

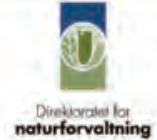

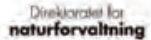

MILJØMINISTERIET

By-og Landskabsstyrelsen

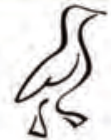

Grønlands Hjemmestyre

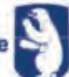

\section{(J)}

UMHVERFISSTOFNUN 


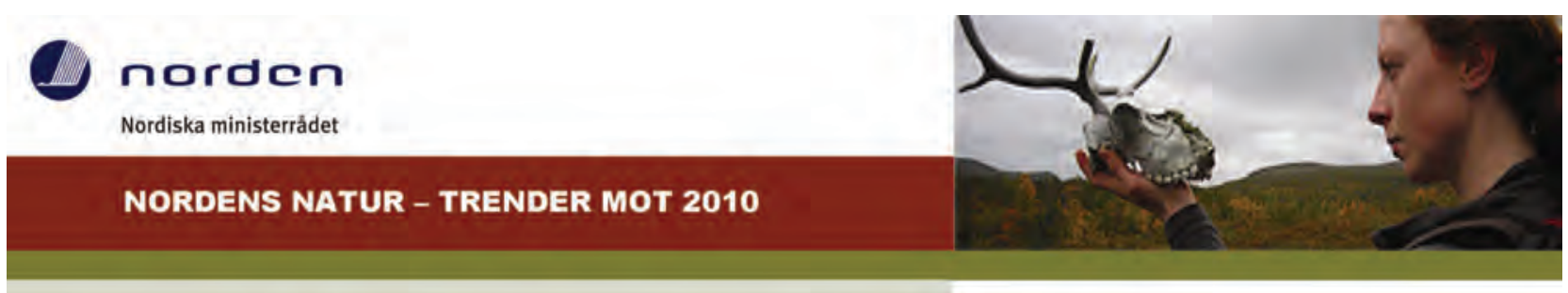

\section{Framgångsrik restaurering och vård av inlandsvatten i Norden}

Insjöar, älvar och andra inlandsvattendrag hyser ett mångformigt liv. Vattendragens och avrinningsområdenas struktur och utvecklingshistoria samt arternas utbredning $\mathrm{i}$ omrádet påverkar floran och faunan, näringskedjorna och biologiska produktionen. För arterna är bland annat vattnets klarhet, syrehalt, näringshalt, surhetsgrad och mängden skadliga ämnen viktiga egenskaper som påverkar vattenkvaliteten.

Mănniskan har också en stor inverkan på vattendragen. Utsläpp till luften försu-rar och avloppsvatten eutrofierar vattendragen, vilket leder till ändringar floran och faunan. Dessutom påverkar skogsavverkning, dikning av våtmarker och torvutvinning vattendragen genom att förändra avrinningens mängd och sam-mansättning. Vi förändrar också vattendragen fysiskt genom reglering och byggning samt genom att rensa och räta ut älvar. Klimatförändringen kan ocksả ha effekter pả vattendragens tillstảnd och deras förmåga att áterhämta sig efter förändringar.

\section{Försurning}

Vid förbränning av fossila bränslen bildas sura svavel- och kväveoxider, som t.ex. vid regn hamnar i miljön och i vattendrag och försurar dem. Intensivare skogsbruk kan ocksă öka försurningen. Försurade vattendrag har funnits mest i södra Skandinavien och södra Finland. Fennoskandiens naturligt sura jordmån och berggrund har dessutom en dålig buffertförmåga; den neutraliserar det sura nedfallet dâligt och det rinner till vattendragen.

Då vattnet blir surare försvinner arter enligt hur känsliga de är för försurning Speciellt känsliga är lax- och karpfiskar samt bottendjur som kräftor, snäckor, musslor och iglar. Insekter som lever i vatten som larver eller vuxna försvinner ur försurat vatten, och med dem också insektätande fáglar. I surt vatten frigörs ocksá aluminium och andra giftiga metaller som skadar djuren. Aluminium fäster sig till exempel på fiskarnas och bottendjurens gälar och försvårar andningen.

Försurning blev ett stort problem i Norden på 1960-talet dả industrin utvecklades kraftigt, men utsläppsreningen ännu var mycket enkel. Sedermera har utsläppen, och därmed det sura nedfallet minskat med hjälp av internationella avtal och utveckling av effektivare reningsmetoder. Det bästa sättet att ăterställa det naturliga tillståndet i försurade vattendrag är internationell luftvárdspolitik och minskning av utsläppen.

\section{Eutrofiering}

Då avfallsvatten från industrin och samhället samt näringsämnen från jordbruket, speciellt kväve och fosfor, hamnar i vattendragen ökar primärproduktionen. Vattenväxter, alger och plankton ökar och orsakar algblomningar och igenväxning. Det är svărt att hejda eutrofieringen eftersom den matar sig själv. Då näringen från den ökade biomassan frigörs i vattnet möjliggörs fortsatt ökning av biomassan. Detta kallas inre belastning.

Eutrofiering av vattendragen minskar artmångfalden; fiskarter försvinner och artsammansättningen ändras. Dá vattnet blir grumligt tränger inte ljuset igenom det och dả försvinner undervattensväxter och bottenväxter. Eutrofierade insjöar mister sitt rekreationsvärde på grund av slembildning på stränderna och utveckling av täta vassbestảnd. Algblomningar stör simmare och karpfiskar ersätter matfiskar. I Norden finns allvarligt eutrofierade vattendrag speciellt i Danmarks jordbruksomráden samt i närheten av tätorter och fiskodlingsanläggningar.

\section{Sjöarna i Köpenhamn restaurerade för rekreation}

I Köpenhamn i Danmark finns tre sjöar, som både har en intressant historia och ett stort rekreationsvärde; Sankt Jørgens Sø, Peblinge Sø och Sortedamssø. Sjöarna består av fem bassänger som är formade av mänsklig verksamhet. Vattnet kommer via underjordiska kanaler från våtmarken Utterslev Mose och Emdrup-sjön. Köpenhamns sjöar fredades redan år 1966, men ända tills ett storskaligt restaureringsarbete började år 2002 var de mycket förorenade och eutrofierade på grund av avfallsvatten. Näringsbelastningen hade minskat redan dá ett litet reningsverk byggdes i Emdrup-sjön år 2000.

Först städades cirka 500 cyklar och annat bråte bort från sjöarna. Sedan fiskades över 32 ton skräpfisk: mört och braxen. Rovfiskar återinfördes genom att inplantera gäddyngel och bygga lekplatser och skyddade ställen för fiskarna. Numera är cirka hälften av sjöamas fiskar rovfiskar. Gäddorna och ett naturligt abborbestånd háller mörtoch braxenbestånden i styr. Med denna biomanipulation uppnåddes goda resultat åtminstone på kort sikt.

Vattnet i Peblinge Sø och Sortedamss $ø$ har igen blivit klart, och år 2002 inplanterades undervattensväxter på sex olika platser. Två små holmar har byggts i Sortedamssø för att fåglar skall kunna häcka. Pả ena holmen finns en liten storskarvskoloni. Holmarna är också viktiga rastoch övervintringsställen för andfåglar.

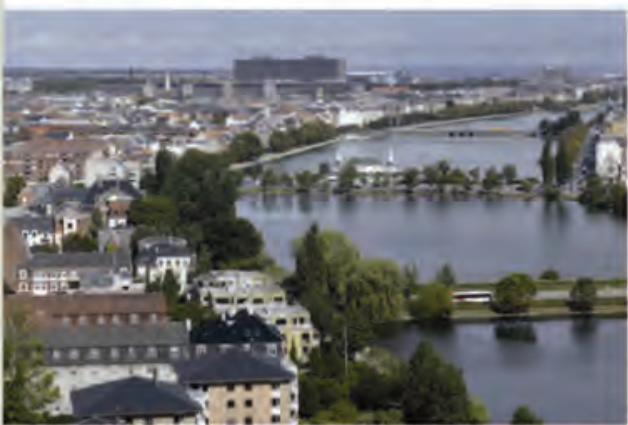

Sjöama $i$ Köpenhamn är igen i gott skick till glädje för invánarna och besókare.

Bild: Mikkel Østergaard/Scanpix. 


\section{Framgångsrik vård och restaurering}

Eutrofierade och försurade vattendrag kan restaureras och i Norden finns många exempel på lyckade åtgärder. Kalkning är ett sătt att återställa sjöars naturliga surhetsgrad. Kalk neutraliserar försurande ämnen och binder aluminium och andra giftiga metaller. Skador orsakade av eutrofiering kan åtgärdas till exempel genom biomanipulation eller năringskedjerestaurering, det vill sãga genom att fiska bort skräpfisk och förstärka rovfiskbestånden, samt genom att syresätta vattnet och slå vegetationen på igenvuxna stränder.

\section{Vesijärvi - frản blàgröna alger till mảngsidig rekreation}

Vesijärvi i Păijänne-Tavastland var i tiderna Finlands mest förorenade insjö, men har genom restaurering blivit en utmärkt rekreationsmiljö för tusentals människor. På 1970-talet förekom stora algblomningar i sjön, som smutsades av både samhällets och industrins avfallsvatten. Trots att ledningen av avfallsvatten till sjön upphörde 1976 och sjön syresattes 1978-1984 fortsatte algblomningen på 1980-talet. Orsaken visade sig vara stora mört- och norsbestånd, som åt djurplankton och dărmed möjliggjorde en ökning av blågrỏna alger. 1987 påbőriades ett omfattande samarbete mellan de omgivande kommunerna, Helsingfors universitet, Vilt- och fiskeriforskningsinstitutet, vattenskyddsmyndigheter, och Vesijärvi fiskeområde för att rădda sjön. Målet var att restaurera sjön så att den skulle duga till rekreationsbruk och fiske.

För första gången prövades biomanipulation i Finland och őver 1000 ton mörtar och norsar, som äter djurplankton, fiskades bort. Rovfiskbeståndet förstärktes genom inplantering av gös samt genom slåtter på gäddornas lekstränder, som vuxit igen. Yttre belastningen minskades också ytterligare. Dagvatten började ledas till avlopp och det gjordes skyddszoner i jordbruket. Resultaten bőrjade synas i bőrjan av 1990-talet. Blågrőna algema försvann, siktdjupet fördubblades och undervattensväxtema återhämtade sig. De inplanterade gösarna har bildat ett ökande bestånd och numera finns också sik, öring, siklöja och stora abborrar i sjön.

Vesijärvi klarade sig ăndå inte utan fortsatt vård och i början av 2000-talet observerades blågröna alger igen. Vărdătgărderna och forskningen intensifierades och hanteringen av glesbygdens avfallsvatten och jordbrukets diffusa utsläpp uppmärksammades mera. Den kontinuerliga vården som sjön kräver skőts av frivilliga och sysselsatta. Professionella fiskare deltar också i minskningen av karpfiskar och sjön skall syresăttas igen.

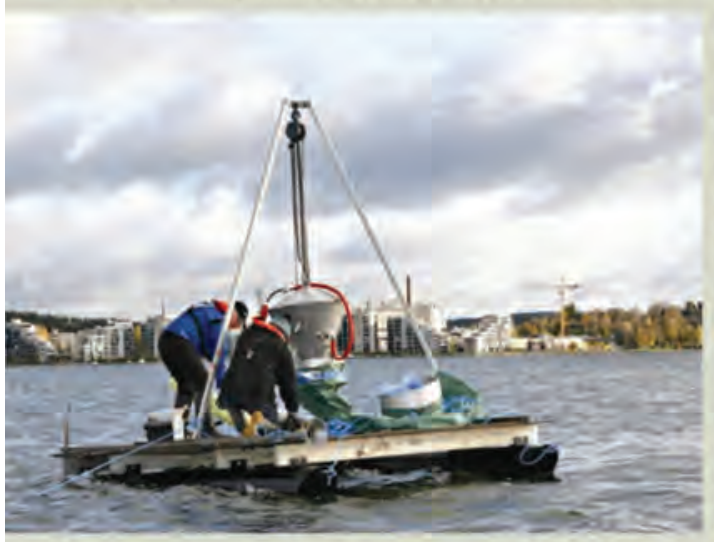

Vesijärvi är den största eutrofierade sjön i Finland, och en av största $i$ Europa, som har restaurerats framgångsrikt. Sjön är ett nationellt och internationellt modellexempel på vattenvård tack vare sina goda resultat och starka betoning på lokalt samarbete. Liknande restaureringsprojekt har startats i över 100 sjöar i Finland.

En syrepump installeras i Vesijärvi i djupet vid Myllysaari Pumpen blir helt under vattenytan och bara en remmare blir synlig. Bild: ESS/Leena Liukkonen.

Litteraturförtekning på faktabladets hemsida: www.miljo.fi/nordensnatur > Faktablad > Restaurering av inlandsvatten

\section{Laxbestànd ảterställda i Sverige och Norge}

I Sverige och Norge åtgärdas försumingens skadliga effekter genom storskalig kalkning. Sveriges kalkningsprogram ăr det största i sitt slag i världen med năstan 9000 kalkade vattendrag. Kalkningen sker antingen direkt i vattnet eller genom att kalken sprids ut $i$ omgivande våtmarker.

Försumingen började i Norge redan på 1800-talet och ökade ända till 1970-talet. Âr 1925 blev det klart att surt vatten orsakade fiskdőd, men sambandet till sur nederbörd förstods först i slutet av 1950-talet. Skadorna på fiskbestånden och den biologiska mångfalden ökade $i$ takt med ökad försurning. Kalkning påbőrjades i medlet av 1980talet. Målet var att uppnå en så god vattenkvalitet att livskraftiga laxbestånd kan återställas. Genom inplanteringar har laxbestånden kunnat återställas i flera ălvar och kalkning har främjat laxens naturliga förökning.

På 1970-talet minskade laxen kraftigt i antal i Fylleån i Sverige på grund av försurning och på 1980-talet var den năra att utrotas helt. Förutom försurning orsakade också utslăpp direkt i vattnet, överfiske och vandringshinder problem för laxen. Fylleån har kalkats sedan 1982 . Tack vare kalkningen och andra åtgärder kan laxen igen föröka sig i ån och laxtätheten har ökat sedan mitten av 1980-talet. Också artantalet av bottendjur, så som insekter, krăftdjur, snäckor och musslor fördubblades under åren 1982-2004. Numera kalkas ån genom två kalkdoserare, som tillför kalken direkt i det rinnande vattnet, samt genom kalkning av kảllsjöar och våtmarkskalkning av ett biflóde till ån.

Kalkning ger goda resultat för laxfiskar, men löse problemet bara tillfälligt och lokalt. För att effekten skall vara önskad, måste kalkningen fortgå regelbundet. Den enda långsiktiga lősningen på försumingsproblemet är en ytterligare minskning av försurande utslăpp.

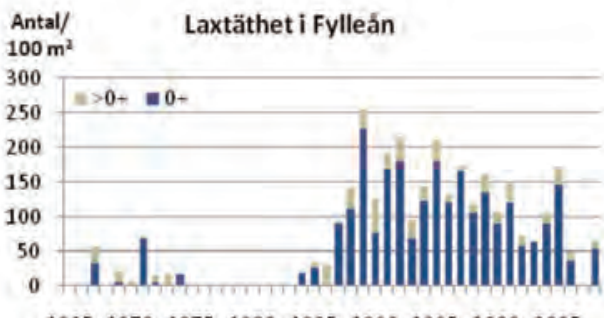

$1965 \quad 1970 \quad 1975 \quad 1980 \quad 1985 \quad 1990 \quad 1995 \quad 3000 \quad 3005$

Tătheten ársungar ( $(0+)$ och äldre ungar $(>0+)$ av lax $i$ Tolarp-omrádet i Fylleản. Kalkningen börjades 1982, dà Tolarp-omradeti fylean Kalkningen bojades 1982 da ocksá en metallindustri som slappto fororeningar direkt àn stängdes. 1986 óppnades en laxtrappa vid Tullgrens kvarn. Källa: Naturvårdsverket.

Finlands miljöcentral SYKE - wuw. miljo.fi/nordensnatur

15.4 .2009

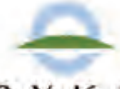

S Y K E

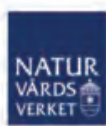

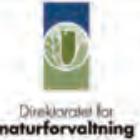
MILJØMINISTERIET

By-og Landskabsstyrelsen

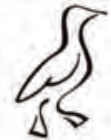

Grønlands Hjemmestyre

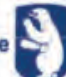




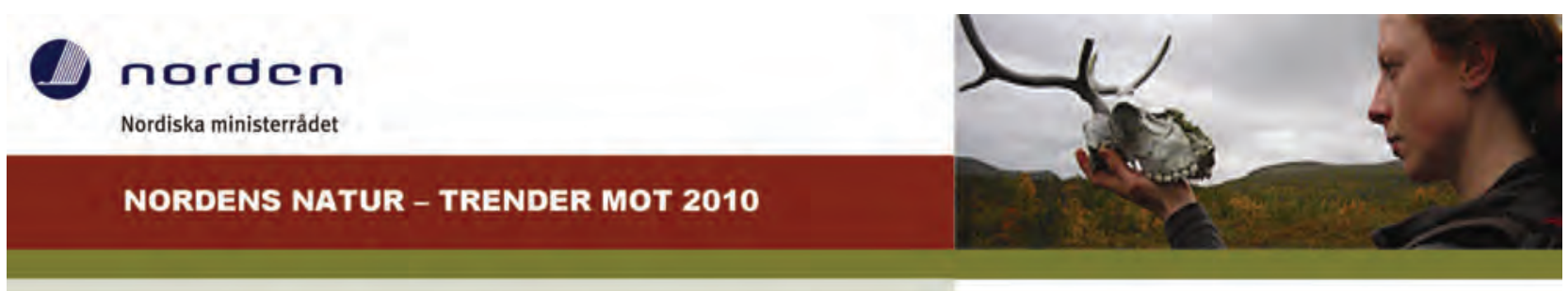

\section{Lokal medverkan för att hejda förlusten av biologisk mångfald}

2010-målet är ett världsomfattande naturskyddsmål. Målsättningen är att hejda förlusten av biologisk mångfald före ár 2010.

För att 2010-målet skall nås krävs det åtgärder i alla delar av samhället. Lokalsamfund, som representeras av kommunerna, har en central roll i och med att de fungerar som myndighet i planeringen av markanvändning och för att de förvaltar en stor del av den biologiska mångfalden. Kommunerna är också en naturlig plattform för att aktivera och engagera allmänheten.

I ett nordiskt projekt etablerades år 2006 ett nätverk av kommuner i Norden som skall genomföra konkreta projekt som är relevanta för 2010-målet. Nätverket skapar en plattform för utbyte av erfarenheter för kommuner i Norden, och för att demonstrera nödvändigheten av lokala insatser för att nå 2010-målet. Nätverket består idag av 14 kommuner. Kommunernas projekt innefattar allt från restaurering, naturskydd, kommunplaner som verktyg och bekämpning av främmande arter till artskydd genom skötsel. Lokalt deltagande och spridning av information om naturen är centralt $i$ de flesta projekten.

För att nå 2010-målet förpliktar sig kommunerna i nätverket till att genomföra konkreta projekt, vars resultat skall gå att mäta. Kommunerna skall också rapportera om sina projekt under år 2009 och sprida information på en egen webbsida. Det är också önskvärt att kommunerna undertecknar Countdown 2010-deklarationen.

I Hammerfest har konstgjorda rev satts ut för att restaurera ödelagda marina habitat. Reven består av rör tillverkade av återvunnet plast, som är fästa vid en betongcylinder. Konstruktionen skapar skydd för fiskyngel och bättre levnadsvillkor för tảng. Avsikten är att ersätta kelpskogen som är kraftigt betad av sjöborrar.

I Stjørdal vill man genom planering av markanvändningen ta hänsyn till biologiska mảngfalden och speciellt skall strandomrảden som fungerar som rastplatser för vadare och andfáglar säkras. Kommunen stöder lokalföreningen Færbøgda i lag, som upprätthåller intresset för traditionellt slåtterbruk. I området finns artrika slåtterängar med blàklocka, prästkrage, vårbrodd, och mer sällsynta arter så som darrgräs och grönvit nattviol.

I Trondheim månas det om att bäckar nära staden skall vara i gott ekologiskt tillstảnd. Ilabäcken är rensad och vattnet är renat, och öring och bottendjur trivs där igen. Trondheim är en viltrik kommun, men livsmiljöerna för många arter hotas av fragmentering. Tjädern används som indikator för önskvärt tillstånd i skogen i Bymarkaområdet. I Lian-Solem-området skall systematisk skötsel säkra området som värdefullt kulturlandskap.

I Örebro har en tidigare soptipp och oljehamn byggts om till naturreservat och dammpark, vilket har resulterat $i$ att flera fågelarter än förr nu finns i området. Det restaurerade området utgör 600 ha och är till stor glädje både för besökare och stadens invånare.

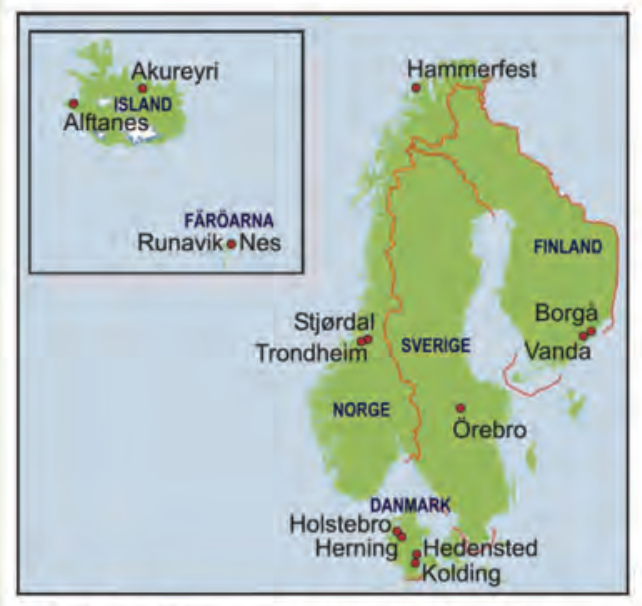

Karta över kommunema som deltar i projektet.

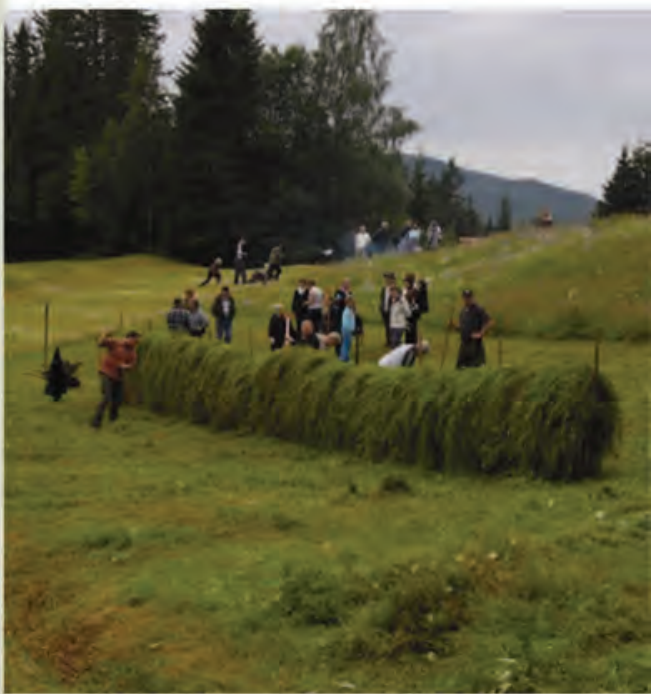

Slåtterdag på en av de artrika ăngarna i Stjørdal. Bild: Ingvild Kalland. 
I Hedensted vill man säkra ett bärkraftigt skogsbruk genom att certifiera skogar vid Vejle fjord. Ett våtmarksområde på 85 ha, inklusive en insjö på 25 ha skall ăterupprättas. Mera varierande fysiska förhållanden i Skjåld å har också positiv påverkan på havsöring, vatteninsekter, andfåglar och vadare. Bete i öppna naturtyper skall säkra botaniskt värdefulla områden.

I Herning är man i gång med att utforma en naturpolitik som skall säkra existerande naturvärden och skapa större sammanhängande naturomrảden. En handlingsplan för lax för Skjern ả-systemet förbättrar levnadsvillkoren för flera fiskarter. Laxen är en god indikator, eftersom den ställer höga krav på livsmiljön. Herning ställer också insatser mot klimatförändringen högt pả dagsordingen, eftersom klimatförändringen också är ett hot mot biologiska mångfalden. Kommunen har satt igång flera energisparande åtgärder.

I Holstebro har 55 dammar etablerats för att skapa bra livsmiljöer för stor vattensalamander, åkergroda, lökgroda och stinkpadda. Oppna områden sköts genom bete för att säkra ljusälskande växters framgång och ett rikt insekt- och fảgelliv. Fördämningar avvecklas för att förbättra rörelsemöjligheterna för lax, öring och nejonögon.

I Kolding förbättras vattenförhållandena i lobeliesjön Skærsjø. I sjön växer notblomster, braxengräs och strandpryl, som trivs bäst i klart och näringsfattigt vatten. Fysiska förhållandena i Åkær-älven förbättras genom att göra flera krökar i den och genom att lägga stenar och grus på en 17 km lång sträcka. Våtmarksområden vid Âkær restaureras också.

Nes och Runavik hör till Färöarnas tillväxtcentra. För att säkra fortbeståndet av ljunghedarna och fågellivet vid Toftavatn skall det skapas kontrollerade ramar för trafik i omgivande områden. Naturförmedling är centralt i projektet.

I Borgá grundas en nationalstadspark som innefattar en stor variation av naturområden och värdefull kulturmiljö. Marens äng, som är gammal hagmark, är ett av de viktigaste områdena i den planerade nationalstadsparken. Skogsröjning och bete skall hindra området från att växa igen.

I Vanda är naturskyddstraditionen lång och $6 \%$ av kommunens yta utgörs idag av naturskyddsområden. Uttöver skyddsområden finns också sk. LUO-områden, dvs. områden som är speciellt viktiga för biologiska mångfalden och som beaktas i planeringen av markanvändning. Pà dessa områden krävs speciella åtgärder för att bevara naturens mångfald.

I Akureyri bekämpas främmande arter på ön Hrisey. Hundfloka, lupin och kvanne täcker idag 11-13\% av ön. För att återskapa karakteristiska ljungområden sås frön från isländska floran. En gammal soptipp pả 30 ha kommer ocksả att passa naturligt in i landskapet som följd av denna åtgärd. Vid Naustaborgir restaureras också ett våtmarksområde för att gynna fảgellivet.

I Alftanes förbättras fåglarnas levnadsområden genom att restaurera våtmarker vid sjöarna Kasthúsatjörn och Dvottatjörn. Ett obebyggt område runt presidentens bostad bidrar till att stärka funktionen av dessa två omráden.

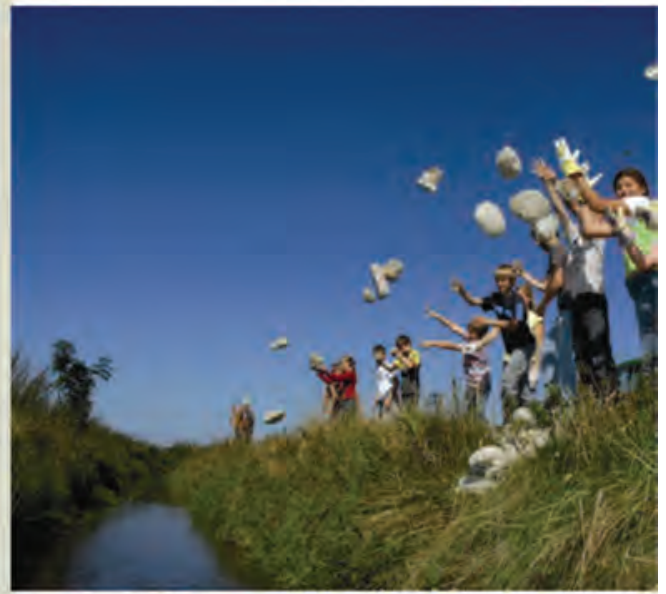

Skolbarn deltar $i$ att värna om biologiska mângfalden genom att kasta stenar i Akær-älven i Kolding. Bild: Kaare Manniche Ebert.

Projektet demonstrerar vikten av natuskyddsarbete på lokal nivå och av kommunen som myndighet i planeringen av markanvändning. De lokala projekten som presenteras ovan visar att åtgärder för att bevara den biologiska mångfalden är värda mödan.

Projektet avslutas år 2010. Slutrapporteringen skall demonstrera nödvändigheten av ătgärder pả lokal nivå för att nả 2010-målet. Resultaten kan motivera andra kommuner, så att nordiska kommuner kan framstå med gott exempel och visa att lokalsamfunden tar vara på biologiska mångfalden. Alla deltagande kommuner kommer naturligtvis att fortsätta sitt arbete med att ta vara på biologiska mångfalden också efter år 2010. Långsiktig uppföljning $i$ de deltagande kommunerna har också diskuterats.

Projektets hemsida vid Direktoratet for naturforvaltning: www.dirnat.no/2010-malet

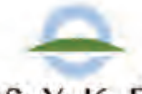

S Y K E

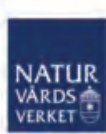

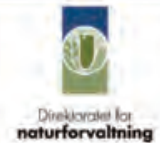

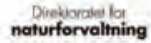

MILJØMINISTERIET

By-og Landskabsstyrelsen

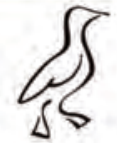

Grønlands Hjemmestyre

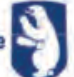

\section{(ग)}

UMHVERFISSTOFNUN 


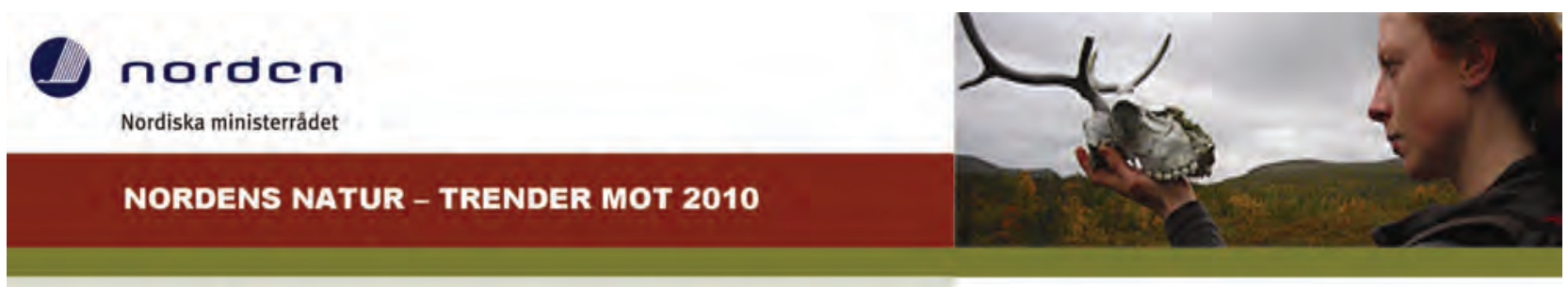

\section{Nordens ängs- och betesmarker hotade}

Kulturbiotoper, dvs. biotoper som har formats av traditionellt ängsbruk med slåtter och bete har sả gott som försvunnit i Norden. Därmed har flera av deras typiska arter blivit utrotningshotade eller dött ut. Bảde i Norden och globalt är ändringar i markanvändningen, och därav följande ändringar i livsmiljön, det största hotet för biologiska màngfalden, bảde för naturtyper och för deras arter. Detta gäller även kulturbiotoper och deras typiska arter.

\section{Naturtyper värda att bevara}

I vår ursprungliga natur har det funnits relativt lite öppna landskap, som t.ex hällmarksängar samt strand- och fjällängar, som har formats oberoende av mänsklig aktivitet. De nordiska länderna har en liknande historia i fråga om traditionell markanvăndning. Under det traditionella jordbrukets tid skapade bete och slåtter öppna vegetationstyper och landskap, som erbjuder ideala förhållanden för växter och insekter som gynnas av ljus, värme och öppenhet. Till dessa mångformiga kulturbiotoper räknas öppna ängar och hedar samt trädbevuxna hamlings-, al- och stubbskottsängar, hagmarker och skogsbeten samt svedjemark. I Norge finns dessutom speciella fäbodslandskap, som har formats av att boskapen har betat på fjällsluttningarna om somrarna.

Ångar fanns mest på 1800-talet. T.ex. i Finland fanns c. 1,6 miljoner hektar, varav bara hälften fanns kvar på 1920-talet. Ängar och betesmarker röjdes till ảkrar eller planterades med skog eller lämnades ăt sitt öde. I samband med att jordbruket intensifierades, och konstgödsling blev allmänt försvann ängarna så gott som helt. Artsammansättningen blev ensidigare och småskaligheten

försvann då den mångsidiga användningen av naturtyperna upphörde och trädoch buskgrupper röjdes bort frản åkrarna och täckdikning ersatte öppna diken. Kulturlandskapens blomstringsperiod tog slut på 1950-1960-talet.

Största delen av kulturbiotopernas arter är ursprungliga arter i Norden. Flera arter kom hit efter istidens slut, då det bildades stäpplika förhållanden där isen drog sig tillbaka. Dả Norden senare blev skogklätt bevarades arterna i refugier på hällmark, myrar, åsar, skogar, Östersjöns stränder eller i fjällen, tills ängsbruk och bete igen skapade mera öppna livsmiljöer för dem. Nu hotar dessa arter att utrotas, om inte deras livsmiljöer - obearbetade och ogödslade ängar och beten - upprätthålls med hjälp av vård eller om inga ersättande livsmiljöer hittas.

\section{Kulturbiotoper hotas av ändringar i markanvändningen}

Kulturbiotoperna hör till de artrikaste naturtyperna i Nordeuropa. De små resterna som ännu finns kvar hotas framför allt av upphörandet av traditionell boskapsskötsel och därav följande igenväxning samt eutrofiering på grund av gödsling. De bästa markerna har tagits i intensivt odlingsbruk, eller bebyggts. Skogsbruket tävlar ocksả om mark med jordbruket och kulturbiotoper har planterats med ekonomiskog.

I Danmark har mycket ängsmark röjts till åkrar eller lämnats utanför det traditionella bruket. Numera är ängar och andra öppna naturtyper skyddade i naturskyddslagen och de får inte röjas. Traditionell slåtter och bete har ändå inte fortsatt, eftersom det kräver fortgảende arbete. Nordeuropas mest varierande kulturlandskap finns i Norge, och en stor del av dem är fortfarande intakta. Slagna områdens area minskade ändå med över $90 \%$ under 1900-talet. I Europa finns bara c. $1 \%$ av ängarna kvar. I Sverige har en större del av ängarna bevarats, c. 200000 hektar, jämfört med tex. Finland, där endast några tusen hektar finns kvar.

På Island, Färöama och Grönland finns inte kulturbiotoper som är jämförbara med dem i Finland, Sverige, Norge och Danmark, som är formade av det traditionella ängsbruket. På dessa öar pågår ändå nu en liknande ändring i jordbruket, som redan upplevdes i resten av Norden, dvs. ett skifte från småskaligt traditionellt jordbruk till intensivare jordbruk på större områden Ändringar i de öppna landskapen upplevs redan pá Island, där antalet fảr har minskat och överbetet lättat. Det har lett till snabb succession, ökad biologisk produktion, åndrad artsammansättning och täta buskage. Pả Färöarna finns

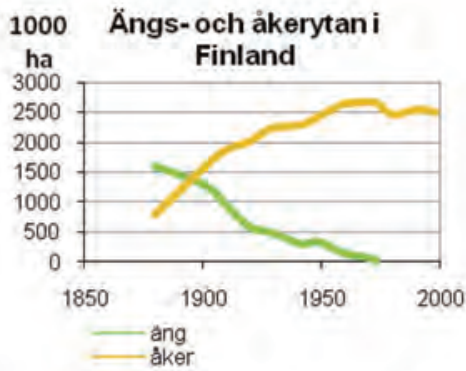

Sedan s/utet av 1800-talet har angsytan i Finland minskat betydligt i takt med att akerytan har okat, da ängar bl.a. har tagits i odlingsbruk. En liknande utveckling har skett ocksá $i$ Sverige och Danmark Källa: Statistikcentralen 2001: Finlands statistiska àrsbok 2001 Soininen, A. 1974: Vanha

maataloutemme. Maatalous ja maatalousväestò perinnăisen maatalouden loppukaudella 1720-luvulta 1870-luvulle. - Historiallisia tutkimuksia 96:1-459.

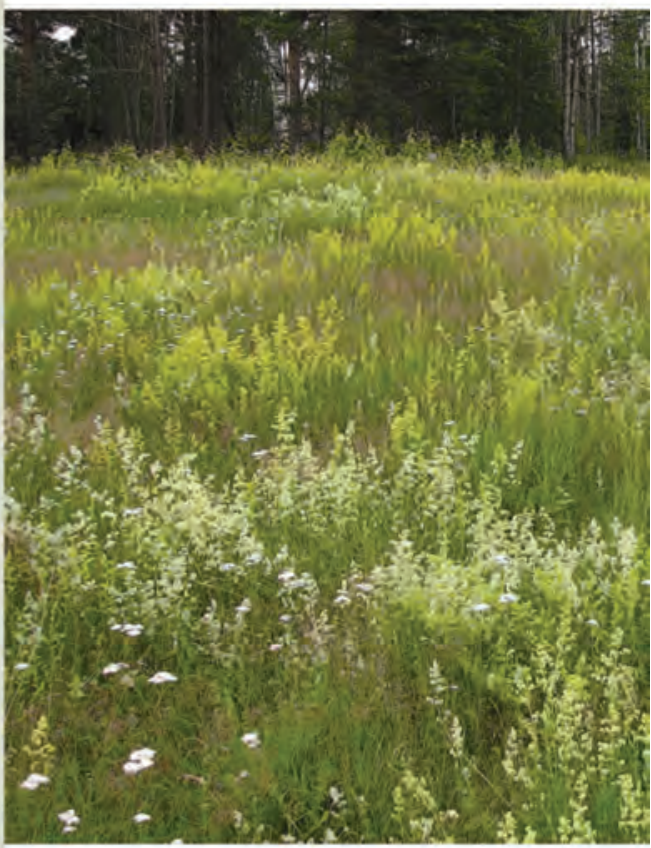

Gulmáran (Galium verum) àr en av de finska kulturbiotopernas hotade arter. Den hotas av förlust av växtplatser och dessutom av en främmande art; stormáran (Galium album). Stormäran korsar sig med gulmáran och bildar hybriden gräddmàra (Galium x pomeracium). Bàde stormáran och gräddmáran har pomeracium). Bade stormáran och graddmaran hor
storre framgång pá igenvaxaande och eutrofierade omráden än gulmáran, och hotar att korsa bort den. Pá bilden syns báde gulmára och den vita stormáran, samt den ljusgula hybriden. Bild: Sonja Forss. 
tecken på att vegetationen skulle bli mångsidigare om betestrycket från får minskade.

\section{Skötsel skyddar kulturbiotopernas artmångfald}

Kulturbiotopema hör till de mest hotade naturtyperna i Norden. Anngar, betesmarker och svedjemark finns kvar bara som små fragment. Växtartrikedomen möjliggör också en rik fơrekomst av djur, så som fjärilar, steklar och skalbaggar. Fågellivet är rikt speciellt på hamlingsängar och hagmark. Dessutom har kulturbiotoperna egna speciella artgrupper, så som dyngbaggar, svampar, mossor och epifyter på hamlade träd. Minskningen i arean av kulturbiotoper har resulterat i att en stor mängd arter har blivit utrotningshotade. Bevarade kulturbiotoper måste skötas och hållas öppna för att de och deras arter skall bevaras åt kommande generationer.

Grundprincipen i skötseln av kulturbiotoper är att med hjälp av slåtter och bete avlăgsna văxtbiomassan som tillkommer under sommaren, samt năringen som finns bunden i den. Annars leder nedbrytningen av biomassan till eutrofiering samt bildning av föma, som kvăver ångsarterna. I trädbevuxna kulturbiotoper är ett ytterligare mål att bevara mosaiken av äng och träd samt att värna om enskilda, stora, gamla trăd.

Bete ăr ett naturligt sătt att sköta kulturbiotoper och nästan enda săttet på trädbevuxna stăllen. Specieltt artrika hamlingsängar borde ăndå också slås ibland för att vegetationen skall bevaras. Då ljusmängden och temperaturen őkar samt jordmånens näringshalt minskar gynnas lågvuxna văxtarter som är ljus- och värmeälskande och som har anpassat sig till låg näringshalt. Betesdjurens trampande blottar markytan och underlăttar groningen av őnskade frön. Slåtter ăr en annan traditionell skötselmetod. I slătter nås de bästa resultaten om man använder traditionella redskap, dvs. lie och skära. Också med slåtter är målet att hindra konkurrensen av näringskrävande arter och gynna de lågvuxna ljus- och värmeälskande växtarterna.

Skillnaden mellan bete och slåtter ăr att djuren betar vegetationen ojămnt. selektivt och lite i taget. Slåtter däremot avlägsnar altt på en gång. Å andra sidan kan djuren ställvis tillföra näring till marken om de får tilläggsfoder. Tidpunkten för både slåtter och bete måste avvägas noga, så att växterna hinner blomma och sătta frön. Samtidigt måste det säkras att möjligast lite döende biomassa blir kvar på marken och eutrofierar området. Efterbete främjar ofta utvecklingen av en mångsidig vegetation på ängar, vilket $\mathrm{i}$ sin tur ökar djurartrikedomen.

För att bevara kulturbiotopernas arter ăr det nödvăndigt att stöda traditionelit bruk av dessa biotoper samt att frămja arternas möjlighet till framgång $i$ andra öppna biotoper, så som öppna områden under kraftledningar, väg- och dikesrenar och gårdar. Miljöunderstöd för jordbruk och Life Nature-understöd riktas också till skötsel av kulturbiotoper.

Traditionell slåtter med traditionella redskap begränsas av att det är väldigt arbetsdrygt. I Finland slås ängar av bland annat sysselsatta och frivilliga från olika organisationer. Också i Danmark har frivilligt arbete en stor betydelse. Ett hinder för bete är däremot bristen på betesdjur. Numera fungerar en betesbank i Finland, och i Danmark en betesförening, som hyr ut betesdjur för bruk i landskapsskőtsel.

\section{En ljus framtid är möjlig för kulturbiotoperna}

Husdjurshållning som baserar sig på ängsbruk och bete återvänder knappast. Inte heller öppna diken eller matsäds- och foderodling utan bekämpningsmede och konstgödsel. Kulturbiotopernas framtid kan ändå se ljusare ut än tidigare, om kunskapen om deras värde och hotade existens ökar. Det finns en vilja att bevara kulturbiotoperna, eftersom de är våra artrikaste och samtidigt mest hotade naturtyper. De är också en del av vår gemensamma historia. Kulturbiotoperna har formats genom văxelverkan mellan människan och naturen, och största delen av våra văxt-, djur- och svamparter förekommer i dem.

Genom att öka skötseln av kulturbiotoper är det möjligt att bevara biologisk mångfald. Framtiden för kulturbiotoperna i Norden beror till stor del på hur bra man lyckas skapa ett nätverk av regelbundet skötta kulturbiotoper. Tiden visar om skőtseln av de kvarvarande kulturbiotoperna har inletts i tid.

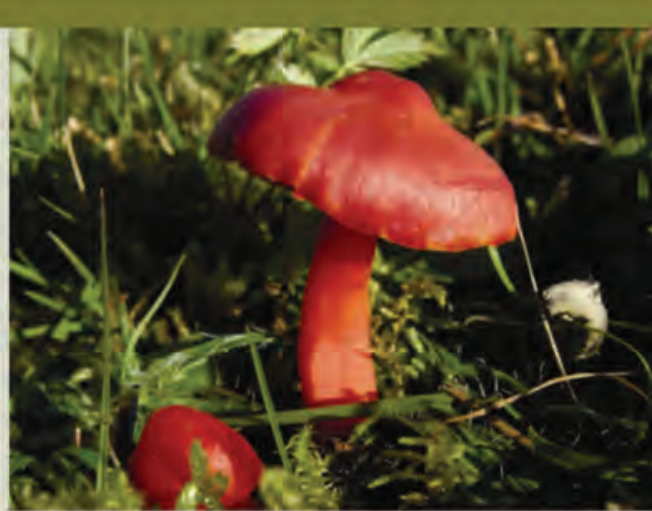

Ángssvampar är en artgrupp som har fấtt lite uppmärksamhet. Angsvampar vâxer pà ogödslade naturbetesmarker och ängar, och är en av de hotade artgrupperne ikulturbiotoperna. Till och med 20-25\% av alla kända sulturbioper 作 gen i kulturlandskapet och kan räknas till ängssvamparna. Skandinavien har överlag en hög ängssvampsdiversitet, och därmed ett ansvar att bevara arterna. Bildens praktvaxskivling (Hygrocybe spledidissima) förekommer i ogödslade naturbetesmarker och hotas av igenvāxning och gödsling. Arten är klassad som missgynnad i Sverige och Norge och starkt hotadi Danmark. I Finland förekommer arten inte alls. Bild: J.C. Schou/Biopix

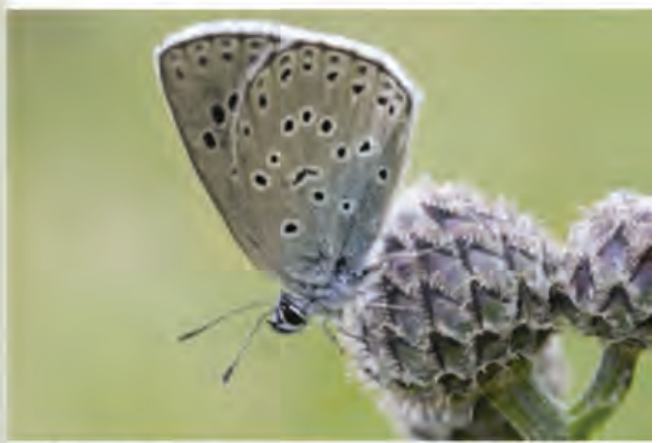

Den svartfläckiga blàvingen (Maculinea arion) är en av de mest hotade dagfjärilarna $i$ Norden. Den är speciellt krävande angảende sin livsmiljö och kräver vissa värdarter för sin utveckling. Honan lägger ägg i back- eller stortimians (Thymus) och ivarmt klimet ockseck stortimjans (Thymus) och ivarmt kimat ocksa kungs myntans (Origanum vulgare) blommor. Larven lever pá blommorna i ett par veckor, tills dess värdart ettermyran (Myrmica) för den till sitt bo. Larven lever därefter som boparasit i ettermyromas bo, där den ocksá ôvervintrar och fórpuppas. Svartfläckiga blàvingen är beroende av bảde värdväxterna och -myrorna, och behöver dessutom öppna, solexponerade livsmiljöer, som har minskat betydligt. I Sverige finns ett tiotal förekomster av svertfläckig blávinge, och i Danmark och Finland finns bara tvá förekomster var kvar.

Bild: Niels Poul Dreyer/Biofoto.

Litteraturförteckning finns på faktabladets hemsida: www. miljo.fi/nordensnatur > Faktablad > Ängs- och betesmarker hotade.

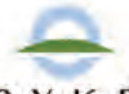

S Y K E

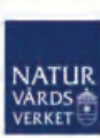

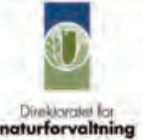

MILJØMINISTERIET

By-og Landskabsstyrelsen

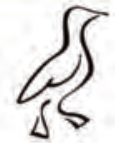

Grønlands Hjemmestyre 


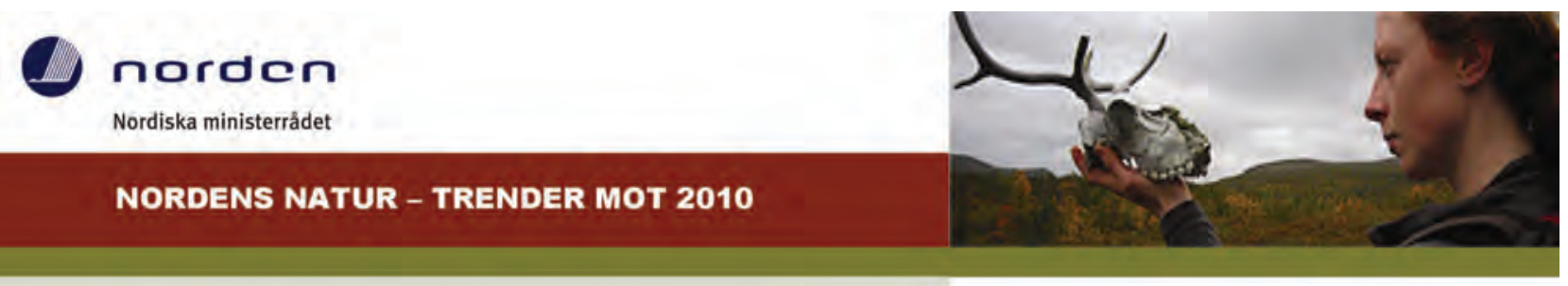

\section{0-årsjubileum för europeiska nationalparker}

Nationalparkerna är natur som finast. De är vảrt naturarv, och nationalskatter som vi bevarar för naturen, oss själva och för kommande generationer. Nationalparkerna är öppna för alla som sevärdheter och rekreationsomráden, och bevaras genom formellt skydd.

Idén om nationalparker kom till i USA på 1870-talet, när bosättningen spred sig mot väster. Då nybyggarna såg den unika naturen i Yellowstone ville de bevara området som allmän egendom. Yellowstone, världens första nationalpark, grundades ár 1872. Australien, Kanada och Nya Zeeland följde snart exemplet och grundade egna parker. Europas första nationalparker grundades i Sverige 1909 , och efter andra världskriget grundades nationalparker runt om i världen.

I Norden sattes diskussionen om nationalparker igång år 1880 av forskningsresanden A.E. Nordenskiöld, och naturskyddsområden grundades från och med början av 1900-talet. I Sverige stiftades den första naturskyddslagen redan 1909, och med stöd av den grundades de första nationalparkerna. Fem parker grundades i fjällområdet, en i ett urskogsområde, två i kulturlandskapet och en på Gotska Sandön.

Ända fram till 1960-talet utgick nationalparkstanken $i$ hög grad från den nationalromantiska idén om att vackra naturlandskap skall bevaras för kommande generationer. Områden skyddades med estetik och rekreation som främsta motiveringar, vilket ledde till att nationalparksnätverket inte motsvarade de målsättningar för bevarande av naturvärden som numera är formulerade för nationalparkerna.

\section{Nationalparkernas naturskyddsvärde}

Det främsta målet med nationalparkerna idag är att säkra den biologiska mångfalden. Parkerna skall representera den typiska naturen $i$ varje land, men också de nationellt och internationellt mest värdefulla delarna av naturen. I nationalparkerna ingår ofta nationallandskap och naturliga sevärdheter. De erbjuder ocksả rekreation på naturskyddets villkor.

Naturskyddet strävar numera efter att i nationalparkerna skydda hela ekosystem eller naturgeografiska områden istället för enskilda, små områden, som inte kan garantera populationernas fortbestånd och en tillräcklig biodiversitet. Mindre naturområden kan skyddas i andra typers naturskyddsområden. Målet med nätverket av nationalparker och andra naturskyddsområden är att bevara ătminstone en del av alla habitattyper $i$ varje land, och att hindra utdöende av arter. Genom ett tillräckligt täckande nätverk av nationalparker och andra naturskyddsområden strävar man efter att säkra den typiska floran och faunan i de naturtyper som ingår, samt ekosystemens struktur och funktion.

I Norden finns det ännu ett stort behov av att skydda ytterligare naturområden. Det kanske allra viktigaste globala naturskyddsmålet är en strategi, Caring for the Earth (1991), som är godkänd av Världens naturskyddsförbund IUCN, FN:s miljöprogram UNEP och Världsnaturfonden WWF. Enligt strategin skall naturskyddsomráden representera alla habitattyper, och $10 \%$ av alla typer skall skyddas. I frảga om skogar avser målet med $10 \%$ framför allt gamla skogar. Nordiska ministerrådet har som etappmål att skydda $5 \%$ av skogsmarken före år 2010.

\section{Nationalparker i Norden}

I Sverige, Norge och Finland finns största delen av nationalparkernas sammanlagda yta i ländernas fjällområden och norra delar. Ytan är dämed inte jämnt fördelad mellan naturtyperna. I övriga delar av länderna är naturskyddsområdena små, och målet med att skydda $10 \%$ av ytan uppfylls inte för naturtyperna i dessa omràden. Kalfjälls- och fjällskogsområden har ocksá varit lättare att skydda än annan mark, eftersom de inte är lika produktiva för skogs- eller jordbruket. Ofta är det tyvärr så att naturskyddsområdena är mindre och mer splitt-
Enligt IUCN:s definition är nationalparker (skyddsomrádesklass II) naturskyddsomràden, där fokus ligger pă skydd av ekosystemen och pà rekreationsbruk. Nationalparker är skyddade land- eller havsomráden i naturtillstând, som grundats för att (a) săkra att ett eller flera ekosystem bevaras i ekologiskt orört tillstănd för nuvarande och kommande generationer, (b) hindra näringar och annan aktivitet som strider mot màlet att skydda omrádet, och (c) skapa möjligheter till mentalt välbefinnande, forskning, naturguidning, rekreation och besőkarservice i samförstán ming, rekreation och besơkarservice i samforstán med miljön och kulturen. Nationalparkernas mi-
nimistorlek enligt IUCN:s kriterium är 1000 hektar.

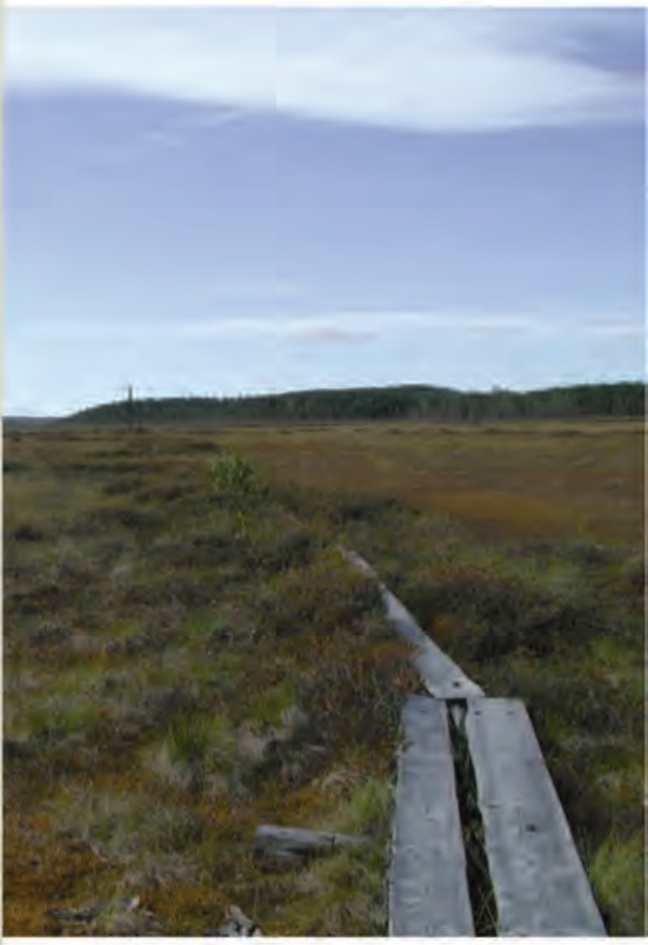

Patvinsuo nationalpark $i$ östra Finland grundades 1982 , och ar ett internationellt betydande myrskyddsoch forskningsomráde med sáväl gamla urskogar som vackra vattendrag. Den avlágset belägna ödemarksparken har ett livskraftigt björnbeständ Foto: Marja Pylvänäinen. 
rade ju produktivare området är. En stor del av Nordens nationalparker och andra skyddade områden ingår i EU:s Natura 2000-nătverk.

I Sverige finns sammanlagt 28 nationalparker. I den svenska nationalparksplanen föreslås nya områden så att representationen av olika naturtyper beaktas bättre. I september 2009 grundas Sveriges 29:e nationalpark, Koster, som samtidigt är den första som skyddar ett havsomráde. I Norge finns 31 nationalparker, och ytterligare 7 pả Svalbard. I Norge grundas den 32:a nationalparken i augusti 2009. I Finland finns 35 , varav 4 är på havsområden.

År 2008 grundades den första danska nationalparken som uppfyller IUCN:s definition. Thy nationalpark ligger i nordvästra Jylland. Ytterligare fyra nationalparker är planerade. Pá Grönland finns en nationalpark, som är världens största och nordligaste. Den grundades 1974 och utvidgades 1988. Parken är nästan en miljon kvadratkilometer stor, varav största delen är inlandsis, men en stor strandremsa ingår också. På Färöarna finns ännu ingen nationalpark, men den första är planerad. På Island finns tre nationalparker, varav den första grundades 1928.

Nationalparkerna har en stark ställning i Norden, men i praktiken erbjuder de ändå inte alltid fullständigt skydd mot utnyttjandet av naturen. Det finns skillnader mellan länderna i hur strikt naturskyddet i nationalparkerna är. I en del av nationalparkerna har dispens givits bland annat för att bygga vattenkraft och vägar, samt för gruvdrift och jakt.

Norden har ett internationellt ansvar för att skydda naturtyper som är säregna just för Norden. Till dessa hör bland annat skärgårdar, landhöjningsstränder, brottdalar, våtmarker, naturskogar, sydliga lövskogar, gamla odlingslandskap, alvar, svedjemarker, outbyggda vattendrag, israndsbildningar och åsar, aktiva vulkan- och geysirområden, sandurområden, Mývatn och stora källfilöden på Island, fågelberg, marina miljöer i Östersjön, Jyllands dynlandskap och Vadehavet. Dessa unika naturtyper skyddas bland annat med hjälp av nationalparker.

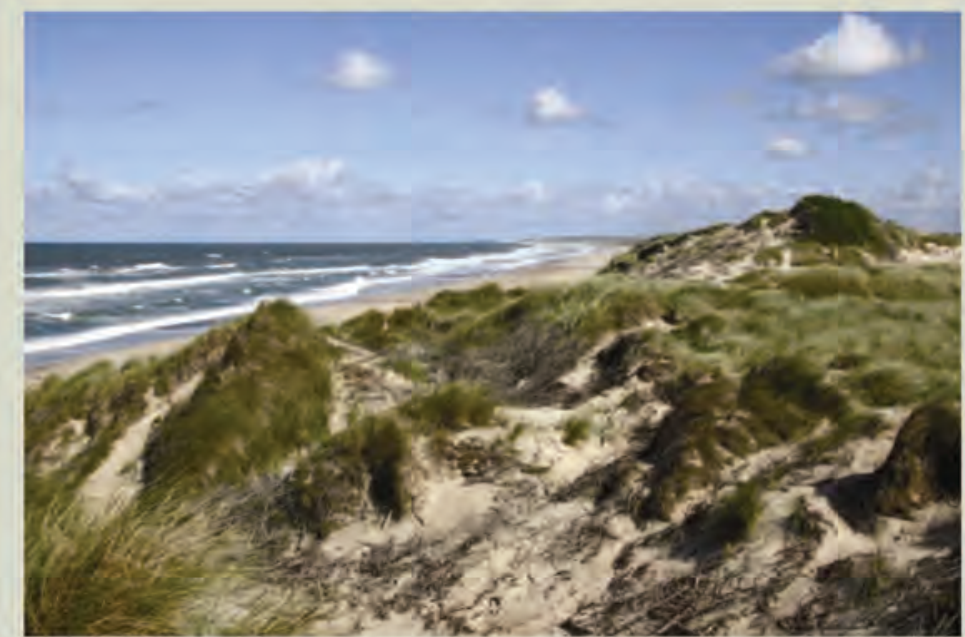

De yttersta dynema vid Hanstholm viltreservat i Danmarks forsta nationalpark, Thy. Bild: Ib Nord Nielsen.

Litteraturförteckning finns på faktabladets hemsida: www.miljo.fi/nordensnatur $>$ Faktablad > Nationalparker

\section{Nationalparkernas rekreations- värde}

Trots att nationalparkernas huvudsyfte är att bevara den biologiska mångfalden och naturens egen utveckling utan ändringar som orsakas av människan, har deras värden i flera fall också formats av traditionellt nyttjande som t.ex. renbete. När nationalparker planeras beaktas både biologiska värden, kulturhistoria, unika landskap och nationell historia, och människor garanteras en möjlighet att njuta av vårt gemensamma naturarv.

Alla har fritt tillträde till nationalparkerna, och $\mathrm{i}$ dem finns ofta guidecentra, stigar, mojjighet till lägereld, stugor och annan service. Nationalparkerna erbjuder möjligheter till friluftsliv och rekreation på naturens och naturskyddets villkor. Guidecentren erbjuder guidning och information och strävar efter att öka människornas medvetenhet om biologiska mångfaldens betydelse.

Människors stora intresse för orörd natur - naturturism - kan också hota nationalparkernas naturvärden. Naturen belastas av trafik till parkerna samt av stora besőkarantal. $\AA$ andra sidan är de som producerar rekreationstjänsterna motiverade att bevara områdena i naturligt tillstånd, sá att de lockar besökare också i fortsättningen. Turismen erbjuder också inkomster för lokalbefolkningen, som kan ersätta eventuella inkomstbortfall pă grund av naturskyddet, om tidigare näringsformer begränsas.

\section{Andra skyddsomrảden kompletterar nät-} verket av nationalparker

Tillsammans med nationalparkerna bildar naturreservat, odemarksomráden, naturminnesmârken, särskilda skyddsomráden för naturtyper och arter, landskapsskyddsomráden samt vârd- och skyddsomráden for naturresurser ett natverk av skyddsomraden for naturesurser ettnatverk av naturskyddsomraden i Norden. Natverket kompletteras dessutom av EU:s Natura 2000-nätverk samt privata naturskyddsomráden. Naturskyddet fórverkligas genom lagar, forrordningar, beslut och direktiv.

Den europeiska parkdagen firas ảrligen den 24 maj pả initiativ av organisationen EUROPARC. Organisationen som representerar Europas naturskyddsomráden, förenar nationalparker, regionala parker, naturreservat och biosfäromràden i 39 lander, med syte att skydda den unika máng-

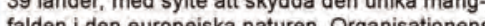
falden i den europeiska naturen. Organisationens medlemmar utgórs av 500 olika aktorrer, som bildar ett specialistnătverk, som vărnar om Europas gróna juveler, dvs. vảrt gemensamma natur- och kulturarv.

Finlands miljöcentral SYKE - www miljo fi/nordensnatur

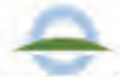

S Y K E

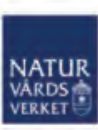

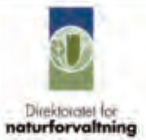

\section{MILJØMINISTERIET}

By-og Landskabsstyrelsen

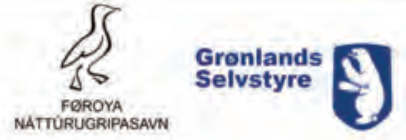

UMHVERFISSTOFNUN 


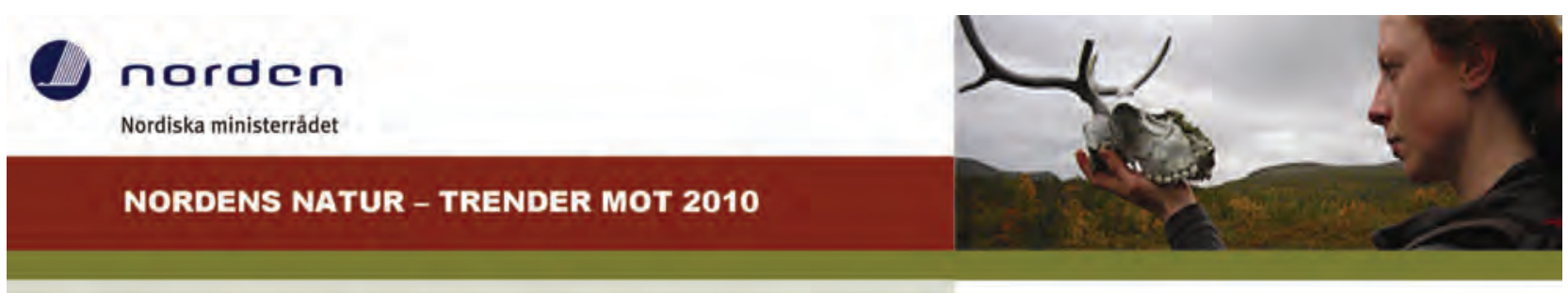

\section{Hot mot biodiversiteten i Norden}

Den biologiska màngfalden, som är ett villkor för liv pả jorden, har minskat oroväckande mycket under de senaste 100 àren. Att livsmiljöerna ändras sá att de blir olämpliga för arterna är det största hotet mot biodiversiteten både globalt och i Norden. Förlusten av biologisk mángfald är ocksá lika stor i Norden som annanstans i världen.

Som en följd av ändringar i markanvändningen försvinner, krymper eller försämras livsmiljöerna. Dá naturliga omráden tas i odlingsbruk eller bebyggs blir det mindre och mindre utrymme kvar för den biologiska mångfalden. Försämringen av de bevarade ekosystemen beror på fragmentering, klimatförändring och förorening. Hoten mot biodiversiteten riktas främst mot livsmiljöer och påverkar därmed arternas bestånd, arvsanlag och existens.

Andra stora hot för biodiversiteten är främmande arter och klimatförändring. Fångst, jakt, insamling samt fiske och bifångst påverkar direkt arternas bestănd medan utsläpp orsakade av människan eutrofierar, försurar och förorenar livsmiljöer och således påverkar arternas fortbestånd.

\section{Ändringar $\mathbf{i}$ markanvändningen har betydande inverkan}

Markanvändning och utnyttjandet av naturresurser har format livsmiljöerna genom tiderna. När livsmiljön ändras, ändras också artsammansättningen och arternas dominans. Ofta är ändringen till det sämre för arterna, ifall det inte är frăga om att området skyddas.

Ändringarna i markanvăndningen beror pả den växande ekonomiska verksamheten, som ökar trycket för att allt effektivare utnyttja marken och naturresurserna. För biodiversiteten är de allvarligaste ändringarna i markanvändningen att så kallade oproduktiva naturliga miljöer, såsom myrar och våtmarker dikas eller dräneras och tas i bruk inom jordbruket, skogsbruket eller torvtäkt.

De biotoper som har lidit mest av intensifieringen av jordbruket och upphörandet av jordbruk pả lågproduktiva jordbruksområden är kulturbiotoperna, som har formats av det traditionella jordbruket. Upphörandet av bete och slătter har lett till att traditionella, artrika jordbruksmiljöer växer igen och går förlorade, och deras arter är numera starkt hotade. Intensifieringen har ersatt det traditionella kulturlandskapet med enformiga, gödslade, maskinellt skötta, täckdikade öppna ăkrar, som saknar dikesrenar och trädgrupper och deras rika flora och fauna.

Intensivt skogsbruk har gjort skogarnas artsammansättning och åldersstruktur enformig, och förstört gamla naturskogar rika på död ved och träd med bohăl och därmed gjort ett stort antal gammelskogsarter hotade. Fjällnaturen ändras ställvis av kraftigt bete och därav följande slitage och erosion, medan den ställvis växer igen på grund av att säterbruket upphört.

Bebyggda områden och trafiknät breder ut sig över naturområden och blir tätare på områden som redan är tätt bebyggda. Skogsbilvägarna sträcker sig till de mest avlägsna ödemarkerna i Norge, Sverige och Finland och splittrar de sista enhetliga naturomrảdena. Ocksá på Island och Färöarna kan de mest avlägsna områdena nås land- eller havsvägen, och resandet och trafiken har ökat kraftigt. Arternas populationer isoleras frản varandra, vilket hotar den genetiska mångfalden. Fritidshus och annat byggande pă stränderna ändrar strandnaturen. Den ökande naturturismen med tillhörande terrängfordon och vattentrafik bidrar till ökad störning och ökat buller.

Vattenbyggande har ändrat älvar och konstgjorda bassănger har täckt stora markomráden. Havsmiljön störs av utvinning av fossila bränslen på havsområden samt vindkraftverk, liksom ödemarker splittras av telemaster. Utvinning, jordtäkt, utfyllnad och deponering förstör livsmiljöer. Orörda naturomrảden finns kvar i Norden bara på Svalbard, och som smà, utspridda naturskyddsomráden.

Minst tre fjärdedelar av Nordens utrotningshotade arter hotas just av ändringar i markanvändningen. Merparten av dessa arter är gammelskogs-, kulturbiotopsoch myrarter. Inom jord- och skogsbruket har man vaknat upp för effektiveringens inverkan på biologiska mångfalden, och problemen har börjat åtgärdas. EU understöder till exempel skötsel av kulturbiotoper genom slătter och bete. Skogs-
En del hotfaktorer har förödande effekter bara lokalt, utan att hota hela naturtypers eller arters fortbestand. Om till exempel grodors dammar växer igen kan de flytta till andra dammar, förutsatt att habitatet inte ăr för fragmenterat. Restaurering av grodornas livsmiljö kan ocksà hjälpa dem att ăterhämta sig, förutsatt att den drabbade populationen inte var artens sista. Andra hot är däremot mera omfattande Andra hot ar daremot mera omfattande och gäller hela naturtyper och deras arter, som till exempel klimatförăndringen som hotar vâr fjallnatur samt inlands- och havsisen.

En del hot är till sin natur akuta, och deras effekter syns omedelbart, medan andra har fördrōjda effekter. Detta beror till exempel pa storleken av artens levnadsomráde. Effekterna av en försämring i livsmiljön kan vara akut för en art som lever pa ett mycket litet omráde, medan en art som lever pả ett större omráde reagerar langsammare genom till exempel minskad narlángsammare genom till exempel minskad năr-
ingstillgâng.

Inverkan av en enskild hotfaktor kan vara liten, medan kombinationer av flera faktorer kan vara förödande. Dessutom ăr verkningsmekanismerna ofta invecklade, och det kan vara svàrt att skilja orsak fran verkan.

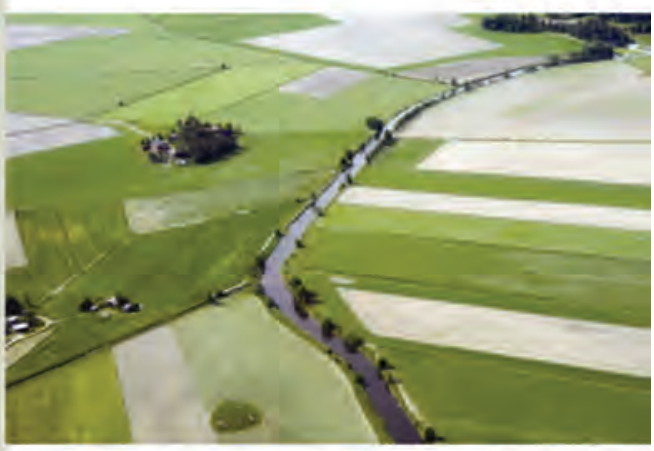

Intensifieringen av jordbruket orsakar ândringar som âr tydliga $i$ landskapet. Dá jordbruken minskar $i$ antal och ókar i storlek blir ákrarna enhetligare och smáskaligheten försvinner. Odlingslandskapet förblir oppet, men blir samtidigt enformigt, och dà lider ocksá den biologiska màngfalden. Odlingslandskap i sydvăstra Finland. Bild. Riku Lumiaro. 
bruksmetoderna ändras så att naturskyddet beak-tas, bland annat så att död ved lämnas kvar i skogen. Vid istảndsättningsdikning av myrar beaktas också inverkan pả kringliggande områden. Ställvis restaureras myrar, vătmarker, kulturbiotoper, källor och andra livsmiljöer.

\section{Främmande arter utgör ett verkligt hot}

Spridningen av främmande arter har globalt klassats som det andra största hotet mot biodiversiteten. Främmande arter sprids till nya områden med människan, då internationell handel, trafik och resande ökar.

En del arter som kommer till nya områden etablerar sig, har god framgång och blir skadliga för områdets ursprungliga arter. Främmande arter, som inte hör hemma i Norden, kallas invasiva dá de konkurrerar med de ursprungliga arterna om näring och livsmiljö, sprider sig och deras populationer blir större, och stör ekosystemets funktion. De kan också sprida parasiter och sjukdomar, som kan ha oväntade verkningar pá de ursprungliga arterna. På grund av klimatförändringen kommer olika livsmiljöers utbredning att ändras och då kommer nya arter troligtvis ocksá att sprida sig norrut. Alla frămmande arter blir ândả inte skadliga.

Att bekämpa främmande arter som redan har etablerat sig är ofta ytterst svårt. I vattenmiljöer kan det vara nästintill omöjligt. De bästa sătten att hindra främmande arters spridning och ankomst till nya områden är förutseende samt effektiv lagstiftning. Arter som redan har förflyttat sig bör utrotas, och spridningen hindras. Deras skadliga effekter pả ursprungliga arter skall ocksá lindras. Ju tidigare bekämpningen pábörjas, desto effektivare är den. Information spelar en central roll i bekämpningen av främmande arter.

\section{Klimatförändringen ett växande hot}

Biologiska mångfalden i Nordens natur hotas av stigande temperatur och ökande nederbörd, som orsakas av klimatförändringen. Klimatförändringen orsakas till stor del av utsläpp av växthusgaser från människans aktiviteter, och dess inverkan beror pả hur utsläppsmängderna utvecklas. Klimatförändringen förväntas ha förödande effekter speciellt för havssträndernas naturtyper, naturtyper dăr tjăle förekommer samt glaciärer och deras arter.

Klimatförändringen kommer att påverka naturtypers och arters utbredning, och både arter och naturtyper kan till och med utrotas helt. Förändringarna förväntas vara speciellt starka i arktiska områden, eftersom Norra ishavet hindrar arternas spridning längre norrut. Alla arter hinner inte anpassa sig till ändringar i livsmiljoerna, och har inte heller möjlighet att flytta sig i takt med att naturtypernas utbredning ändras. Văr fjalllnatur kommer att ändras då klimatet blir varmare. Fjällarterna förlorar sina livsmiljöer dả skogsgränsen flyttas norrut och högre upp i fjăllen. Naturtyper pả ständigt frusna marker, sásom palsmyrar riskerar att upphöra att existera när permafrosten smälter.

Grönlands dominerande naturtyp, den arktiska tundran, försvinner. Inlandsisarna minskar, liksom havsisen, som är livsviktig för isbjörnen. Kortare isvintrar försvàrar redan nu förökningen för sălar och vikare, vilket är speciellt alarmerande för den hotade och endemiska finska saimenvikaren. Sydligare arter kan ocksá spridas norrut. Den stigande temperaturen kan främja igenväxningen av kulturbiotoper, samt förbättra förhållandena för främmande arter, som dả klarar sig băttre här.

\section{Beskattning av fisk-, val- och viltbestånden}

Växt- och djurarter har utnyttjats med samma kraft som markområden. Under tidens gång har beskattning av populationerna hotat flera arter. Flera fisk-, kräftdjurs-, säl- och valarter har utnyttjats över populationernas formåga att fömyas. Med hjälp av internationella fảngstkvoter och fredning försőker man försäkra att marina arternas populationer inte hotas. Ofta är ảndả kvoterna sả stora att populationerna i verkligheten överbeskattas.

Jakt har alltid förekommit, och många viltarter och stora rovdjur har varit ytterst hotade. Numera regleras jakten med kvoter och man strävar efter att utnyttja bestånden hållbart. Rovdjursbestånden regleras sả att de orsakar möjligast lite skada ăt husdjur. Rovdjursförföljningen har minskat i Norden, men ändă inte upphört, och olaglig jakt förekommer fortfarande.

\section{Kemisk skadeverkan}

Utsläpp från mänsklig verksamhet och därav följande förorening, eutrofiering och försurning orsakar indirekta hot mot arter och deras livsmiljöer. Trots att miljögifterna har minskat i Norden, finns ändå ett överhängande hot om oljeoch kemikalieolyckor.

Ostersjön och inlandsvattnen kommer att eutrofieras să länge som näring hamnar i vattendragen från jordbruket och som avloppsvatten. Ostersjön och många insjöar mår dâligt på grund av eutrofieringen, och sandstränderna hotar växa igen. Utsläppen påverkar också landmiljöer. Kvävenedfallet eutrofierar till exempel kulturbiotoper och försnabbar igenvăxningen.

\section{Hoten annorlunda på Grönland}

Till skillinad frăn resten av Norden är markanvändningen inte det största hotet mot habitat och arter på Grönland. Det största hotet utgörs däremot av för kraftigt utnyttjande av naturen och naturresurserna. I samband med annan störning har framför allt fångst och fiske orsakat tillbakagång av flera däggdjurs-, fågel-, fisk- och kräftdjursbestånd. Tillbakagången hindras numera genom att fastlăgga fângstkvoter på biologiska grunder samt genom fredningstider.

På Grönland orsakar ändringar i markanvändningen eller fragmentering inte problem, eftersom det isfria omrádet längs kusten är stort i förhållande till invånarantalet, och bosåttningen är spridd över hela området. Endast 700 hektar på södra Grönland är i odlingsbruk. Trafiken sker till största delen med flyg eller fartyg, och områdena fragmenteras dărför inte av văgar och annan infrastruktur. Olje- och gasutvinningen samt trafiken ökar ändá hela tiden. På sikt väntas klimatförändringen bli ett betydande hot mot biodiversiteten på Grönland.

Litteraturförteckning pà faktabladets hemsida www. miljo. fi/nordensnatur > Faktablad > Hot mot biodiversiteten i Norden

Finlands miljöcentral SYKE - www miljo fi/nordensnatur 23.10 .2009

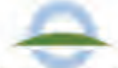

S Y K E

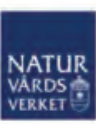

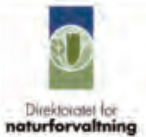

\section{MILJØMINISTERIET} By-og Landskabsstyrelsen

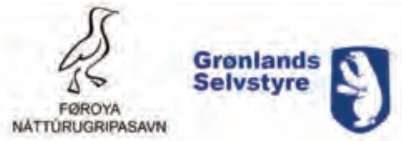




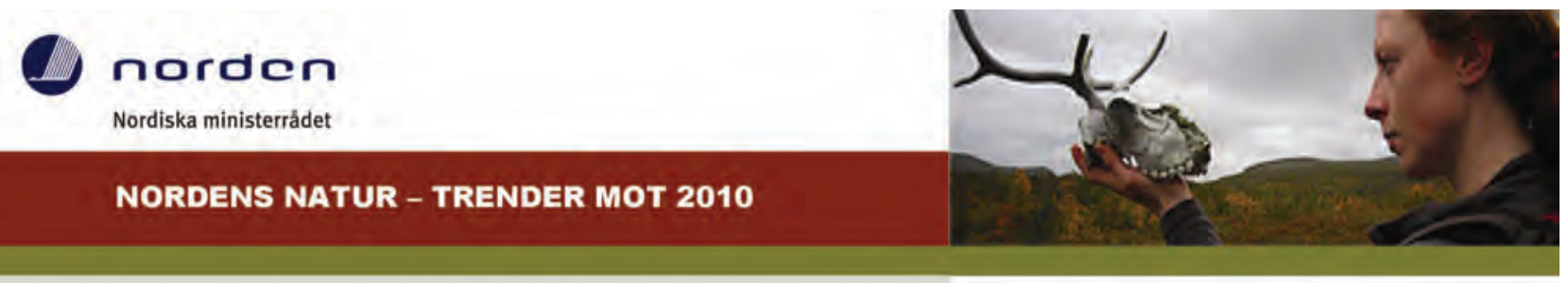

\section{Sandsträndernas rika liv hotas}

Sandstränder och dynomráden vid kusten är speciella naturtyper. De har en säregen flora och fauna och är viktiga som friluftsomráden. Sandstränderna är ändả hotade av mánga olika orsaker, och báde stränderna och deras naturliga arter, som är anpassade till sin krävande miljö, hotar att utrotas.

Pă stränder möts vatten och torra land, och de präglas av ständigt föränderliga krafter; vind, vågor och isens rörelser. Sandstränder och dyner förekommer pà svagt sluttande stränder, där vegetationen har svårt att etablera sig på grund av sandens rörelser. Sandstränderna är solexponerade, blåsiga och naturligt näringsfattiga naturtyper. Văgor och is hämtar iland eutrofierande organiskt material, sảsom alger. Sandsträndernas olika zoner sträcker sig frản vattenbrynet över torra och öppna partier till slutna eller skogbevuxna omráden bakom strånderna. Zoneringen uppkommer dả naturkrafterna flyttar sanden och samlar den på hög.

\section{Specialiserade arter}

Strändernas arter har anpassat sig till ändringar i vattenståndet, och till ett liv varierande vind, salthalt, fuktighet och temperatur samt ett ostabilt växtunderlag. Stränderna har ett rikt liv, eftersom arter från både land- och havsekosystemen förekommer pà dem. Högre upp pá sanden trivs arter som är sega och har ett kraftigt rotsystem, som gör att de tál torka och vind. Den mest typiska växten är strandråg (Leymus arenarius), och numera allt oftare vresrosen (Rosa rugosa), som är en främmande art. Högst uppe, där förhållandena är stabilare, växer örter, gräs, buskar och träd och stranden övergär i strandäng eller skog.

Gömd i sanden och skyddad av vegetationen lever ocksá en specialiserad och hotad insektfauna. Insekterna är viktig föda för många flyttfảglar och fảglar som häckar på stränderna.

Ett speciellt inslag på sandstränderna är de organiska strandvallarna. De bildas då tảng slits loss och vágorna samlar den till en vall ovanför vattenbrynet. Tảngen förmultnar och bildar ett näringsrikt substrat för strandväxter som tål salt och höga näringshalter. Dessa arter bildar ofta täta bestånd i tångvallarna. I synnerhet i Norge är tảngvallarna en typisk naturtyp, där det växer utrotningshotade växtarter.

Hoten mot Nordens sandstränder orsakas av människan

Gemensamt för sandstränderna och dynerna vid Nordens kuster är att de hotas av olika förändringar orsakade av människan. Under de senaste decennierna har ytan av näringsfattiga stränder minskat. Sandstränder och dynomráden förändras av igenväxning som följd av eutrofiering, klimatförändringen, byggande, utfyllnad och slitage på grund av friluftsliv. Sandstränderna hotas ocksá av ökande fartygstrafik och oljeolyckor.

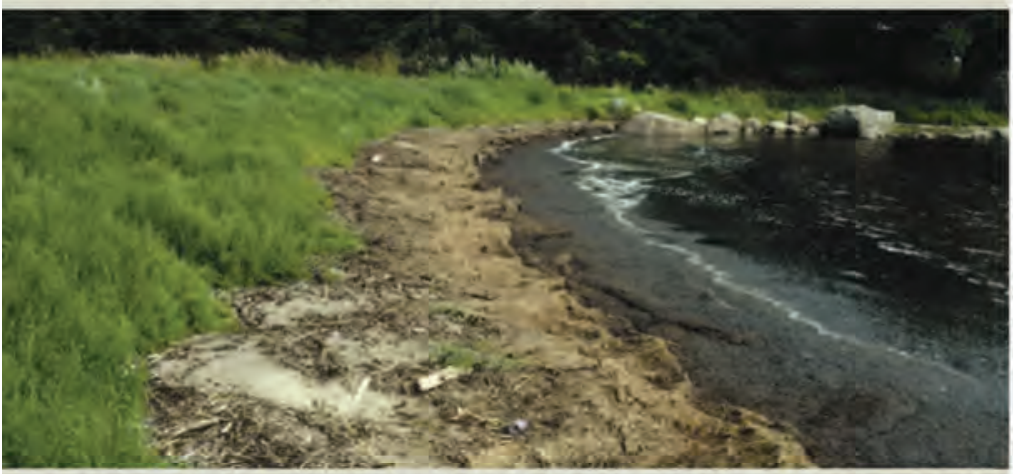

Eutrofierad och igenvuxen sandstrand utanför Kotka i sydóstra Finland. Bild: Terhi Ryttari.

\section{Sandstränder i Norden}

De största sandstränderna och dynområdena i Norden finns pả văstra Jylland vid Nordsjökusten, och lăngs med Sveriges sődra kust. Sandstränder och dynomráden finns ocksá pá kusten vid Kattegatt, Belthavet och Öresund. Pa ásőarna i Finska viken och pà Hangő udd finns rikligt med sandstrănder. Representativa sandstränder finns dessutom längst in i Bottniska viken. I Norge finns smả sandstrănder och dynomràden längs kusten, förutom pà Vest-

landskusten. De största dynomrädena i Norge finns

i Finnmark. Pả Făröarnas, Islands och Grönlands kuster finns bara smà sandstrånder, mest pà grund av att oarna är utsatta för starka vindar och havsströmmar. Sandstränderna pà Grönlands östkust är viktiga landgangsplatser för valrossar.

\section{Dyner}

Dyner ẩr upphōjningar av sand, som bildas dả vin den flyttar pả sanden, som sá smảningom samlas pả hög dả vinden möter ett hinder. Dynernas olika naturliga utvecklingsskeden har alla en săregen flora och fauna. Arterna har anpassat sig till att sanden befinner sig i ständig rörelse. Dynerna är viktiga rekreationsomráden, men de hotas av slitage och byggande.

Danmark ăr dynernas stormakt, och i Europa finns mera dyner bara i Frankrike. Pà Nordsjökusten i Danmark kan man se alla olika stadier i dynutvecklingen samt deras typiska våxtsamhällen. En speciell strandnaturtyp för Danmark ăr vandrande dyner. Det finaste exemplet pà vandrande dyner, Rabjerg Mile, som ocksá är den största i Europa, finns i Jyllands nordspets. Med hjälp av skyddsátgärder tryg gas dynens vandring frán Nordsjôn till Kattegatt.

Mindre dyner finns ocksà pá andra omräden $\mathrm{i}$ Norden, t.ex, vid Bottniska vikens kuster i Finland och Haparanda skärgàrd i Sverige. I Sverige är vandrande dyner vanliga. I Norge förekommer dyner rande dyner vanliga. I Norge förekommer dyner speciellt vid ändmoräner och i stora floders deltan. dynomrâden finns i landets norra delar, men de ho tas av utfyllnad vid văgbyggen, drănering till odlingsmark och erosion pả grund av hàrd sjögảng. Färóarnas enda dynområde, Sandur, pả ôn Sandoy, år skyddat pá grund av forrekomst av arter som inte finns annanstans pá Färöama. Sandtäkt har varit det största hotet mot omrádet, men i och med skyddet har det upphört.

De största hoten mot dyner utgörs av vresrosen samt byggande av fritidshus. I Danmark förekommer konflikter med strandbebyggelsen, dả den vandrande sanden erövrar omraden. Stugägare försöker hâlla sanden orörlig genom att sá sandrör (Ammophila arenaria) och plantera barrtrăd. Detta leder till att dynernas naturliga utveckling hindras och till att dynerna sá smáningom beskogas. Străndernas och dynernas naturliga dynamik och utveckling hindras ocksa av strukturer som byggs som erosionsskydd vid vattenbrynet. 
Ett av de största hoten mot sandstränderna och dynerna vid Östersjöns kust är eutrofiering. Näringsbelastning från jordbruk, samhällen och fartygstrafik gör att trádalger och vass ökar. De flyter iland och skapar goda växtförhállanden för arter som gynnas av hög näringshalt. Sandsträndernas typiska växter hamnar i underläge och igenväxningen av stränderna försnabbas.

Sandsträndernas typiska livsmiljöer och arter hotas av att istäcket minskar som en följd av klimatförändringen. Under normala isvintrar fryser Finska viken och Bottniska viken helt och hället, och andra delar av Östersjön fryser átminstone längs med kusten. Isfria vintrar kan förändra stränderna, eftersom isen normalt sliter och formar strändernas typiska vegetation. Den naturliga bildningen av dyner kan ocksả hindras av att klimatförändringen ökar nederbörden och stormarna. Då stiger grundvattennivån och dynerna beskogas snabbare.

Pă flera hăll skyddas strånder mot slitage och erosion med hjälp av dammar. erosionsvallar och vågbrytare. I Danmark och Sverige återförs sand från havsbottnen till eroderade sandstränder. Erosionsskyddet hindrar ändå den naturliga växelverkan mellan havet och stranden och hindrar strändernas naturliga utveckling.

Fritidshus och annan bebyggelse pá stränderna formar stränderna och orsakar trafik och slitage. Stränderna slits och skräpas ner ocksả av annat fritidsbruk, såsom ridning och trafik med motorfordon. Jord- och sandtäkt samt dikning på fuktiga och försumpade dyner och skogsbruk pá skogklädda dyner ändrar ocksả naturen pá sandtåckta strandnaturtyper.

\section{Skydd är nödvändigt}

Sandstränderna behöver skydd, eftersom de har hamnat i trångmål då strandvegetationen ökat och orsakat ändringar i strändernas naturliga förhällanden, såsom ljus, näringsfattighet och sandens rôrlighet. De öppna sandytorna minskar och den säregna floran och faunan, som har anpassat sig till de speciella förhâllandena hotar att utrotas då deras livsmiljöer försvinner.

I motsats till de andra nordiska länderna, där ett byggförbud gäller inom 100300 meter frản vattenbrynet, finns det i Finland inget allmänt byggförbud på stränderna. Byggandet regleras och styrs däremot i samband med planläggningen. Alla sandsträndernas och dynernas naturtyper vid Östersjön är hotade Finland, och alla sandstränder i naturtillstånd är skyddade enligt naturskyddslagen. Vistelse på stränderna har ändå inte begränsats, eftersom slitage i viss mån hjälper strănderna att hállas öppna.

Sandstränderna i Danmark är delvis nästintill orörda och hör till Danmarks minst människopåverkade natur. Utmed hela danska kusten gäller ett byggförbud inom 300 meter från vattenbrynet, med undantag för fritidshusområden där förbudet bara gäller inom 100 meter frản vattenbrynet. Innanför byggförbudsområdet får strändernas tillstånd inte ändras. Dyntyper med växttäcke omfattas av biotopskyddet enligt danska naturskyddslagen.

I södra Norge finns knappt några orörda sandstränder. Sandstränderna ligger klimatmässigt och topografiskt pá de mest gynnsamma omrádena och är därför kraftigt påverkade av människan. Brackvattensdeltan, som är viktiga för fảglar, hör till Norges mest produktiva områden, och är därmed också den mest utnyttjade naturtypen. I Norge gäller byggförbud inom 100 meter från vattenbrynet.

1 Sverige är byggande och annan verksamhet som försämrar förhållandena för växter och djur förbjudet. Skyddet gäller land och vattenområden upp till 100 meter från vattenbrynet, och kan utvidgas till 300 meter.

Sandsträndernas framtid är i människans händer. Vi kan främja bevarandet av öppna sandstränder och dyner genom att minska byggande och näringsbelastningen till havet, hindra nedskrăpning och vresrosens spridning, samt genom att motverka klimatförändringen och röra oss på stränderna med eftertanke.

Litteraturförteckning pả faktabladets hemsida: uww.miljo.fi/nordensnatur > Faktablad > Sandstrănder

\section{Vresrosen - sandsträndernas plảga}

Vresrosen (Rosa rugosa), som ursprungligen infördes fràn Asien som prydnadsvăxt, tâcker sà smàningom sandstrănder och dyner och trănger undan de oppna străndernas ursprungliga och sallsynta arter, I Norden âr vresrosen, som gynnas av eutrofiering, en främmande art. Varken import- eller försäljningsförbud har införts. Dả rosen spridit sig till naturen âr den svàr att bekāmpa eftersom den sprider sig effektivt med rotskott samt med vattnet och der sig effektivt me med faglar. Om bara en liten bit av en rot blir kvar i
marken kan den skjuta nya skott.

Bâde i Danmark, Norge och Finland har prov med maskinell rōjning av vresrosen, med efterarbete fôr hand, genomförts, för att âterstâlla goda växtfơrhảllanden fớr de ôppna sandstrândernas sâllsynta vâxter fiárilar skinnbaggar och skalbaggar. I Tisvilde leje vid Sjallands nora kust har vresrosen spridit leje vid sylands norra kur har vresrosen spridit sig kraftigt pá dynerna. For att aterstalla vegetationen gràvdes rosorna upp med grävskopa pả en 1,5 $\mathrm{km}$ lảng străcka under vảren 2007 . Växtrester grằ des ner djupt i sanden. Metoden bedômdes som aggressiv, men à andra sidan ầr dynvegetationen anpassad till ăndringar $\mathrm{i}$ sandens skiktning. Metoden visade sig vara effektiv, och i ár (2009) växte det fram sá fá rosplantor att de kunde gravas upp det fram sa fa vosplantor att de kunde gravas upp med spade. I Danmark genomfors under de kommande ären ett stort projekt för att testa olika metoder för att utrota vresrosen. Ocksả herbicider skall provas. I Norge testas redan kemisk bekämpning.

I Finland sprider sig vresrosen kraftigt vid kusten och i skärgárden. Pà skyddsomrádet i Furuvik i Hangō har vresrosen bekämpats. Rosornas rōtter grāvdes upp med grävskopa âr 2008. Arbetet fortsatte pà váren och hósten 2009 , dả frivilliga rev upp satte pa varen och hösten 2009, dá frivilliga rev upp
rester av rótter för hand. Vảrden var lyckad, men arbetet fortgàr, eftersom rosorna máste avlägsnas flera gànger under pà varandra foljande ăr.

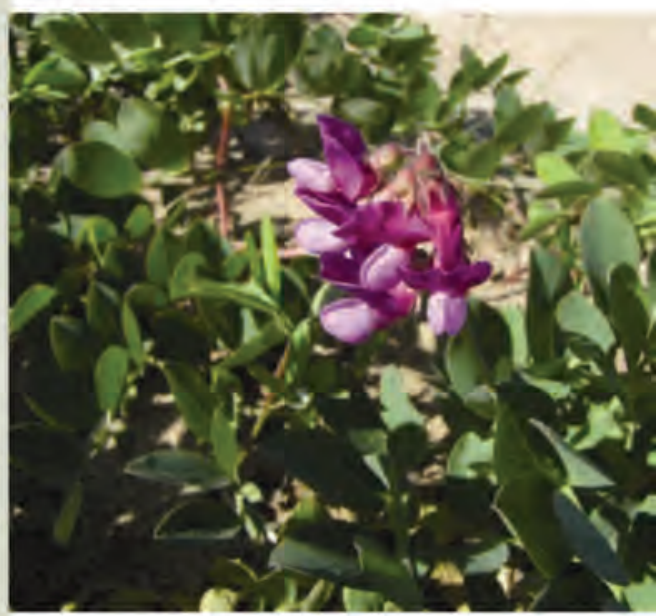

En av sandsträndernas vackraste arter är strandvialen (athyrus japonicus subsp. maritimus), som förekommer. men är sallsynt längs hela Nordens kuster. Bild: Terhi Ryttári.

Finlands miljöcentral SYKE - www. miljo fi/nordensnatur 3.11 .2009

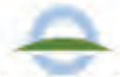

S Y K E

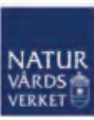

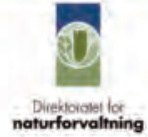

MILJØMINISTERIET

By-og Landskabsstyrelsen

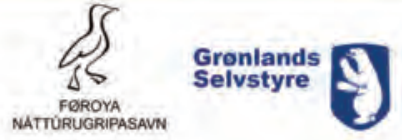

Gronlands
Selvstyre 


\section{I nordon \\ Nordiska ministerrådet}

NORDENS NATUR - TRENDER MOT 2010

\section{Postkort om kommunernas ansvarsarter}

Stinkpadda (Bufo calamita), fältsippa (Pulsatilla pratensis) och glada (Milvus milvus) ăr exempel pả arter som fanns avbildade pả postkost som skickades till alla kommundirektörer i Danmark 1 januari 2007 . Kortet skickades àt kommundirektörema som en nyårshälsning av dảvarande miljöminister Connie Hedegaard. Varje kommun fick ansvar för en hotad art, som förekommer pá kommunens omrăde. Tanken var att páminna Danmarks nya storkommuner om deras ansvar för naturen och att fästa uppmärksamhet vid den hotade naturen.

\section{En speciell nyårshälsning}

I samband med den danska kommunreformen år 2006 upplöstes länen frản och med 1 januari 2007, och därmed fick kommunerna ansvaret för hotade djur och växter. För att påminna kommunema om deras nya ansvar beslöt danska miljöministeriet att genomföra en ny slags informationskampanj. I samarbete med bland annat Danmarks miljöforskningsinstitut, skogs- och naturstyrelse och ornitologiska förening valdes en hotad växt- eller djurart för varje kommun. Postkort med bilder av de valda arterna skickades till alla kommundirektörer och dessutom till lokalpressen i de olika omrädena. Kampanjen fokuserade ocksả pá Danmarks plikt att stoppa förlusten av biologisk mảngfald före ár 2010 och framöver. Postkortet hänvisade till Countdown 2010, som är en internationell kampanj som förmedlar information om 2010mảlet.

\section{En annorlunda kampanj}

Postkortskampanjen hade som mál att uppmärksamma att kommunema tog över ansvaret för naturen och för att öka kännedomen om hotade djur och växter. Genom att välja en enskild art för varje kommun gjordes problemet med hotade arter konkret och handgripligt. Att ge ansvaret till lokala myndigheter ämnade att bảde pảminna kommunema om deras nya ansvar, och öka det lokala intresset. De enskilda arterna ger förhoppningsvis uppmärksamhet ocksá till andra sällsynta arter och deras livsmiljöer i kommunerna.
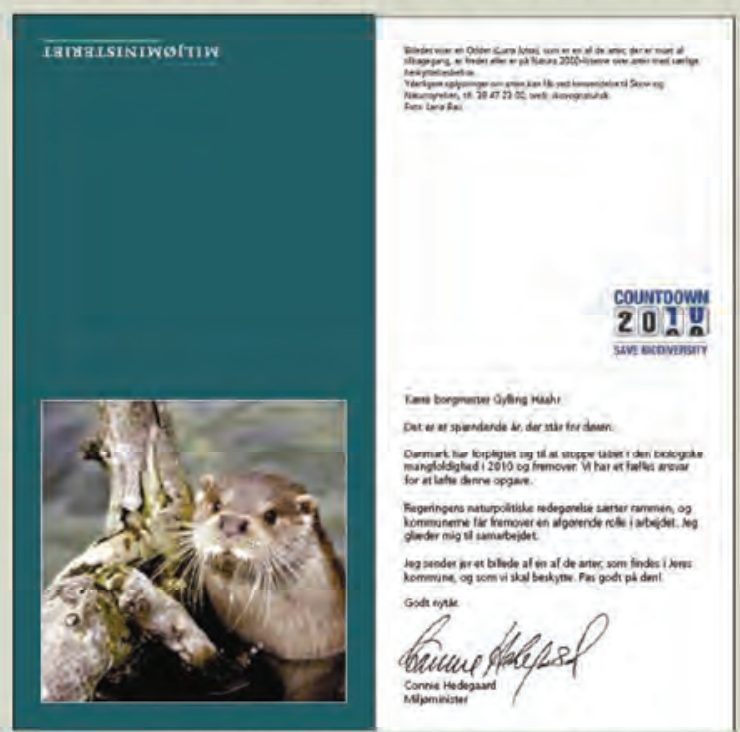

Kortet som skickades till Varde kommun i Danmark, som berattar om den hotade uttern (utra lutra), som forekommer $i$ kommunen. Pả kortet onskas naturskyddssamarbete mellan regeringen och kommunerna. Bild av utter. Gunner Høj Christensen, AQUA

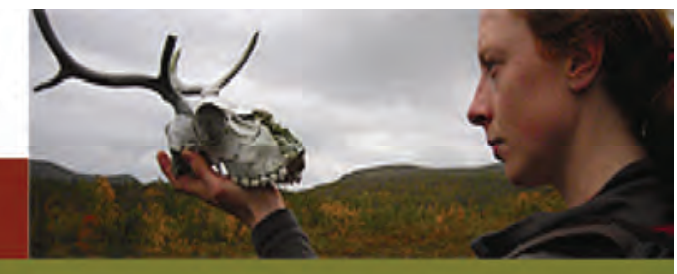

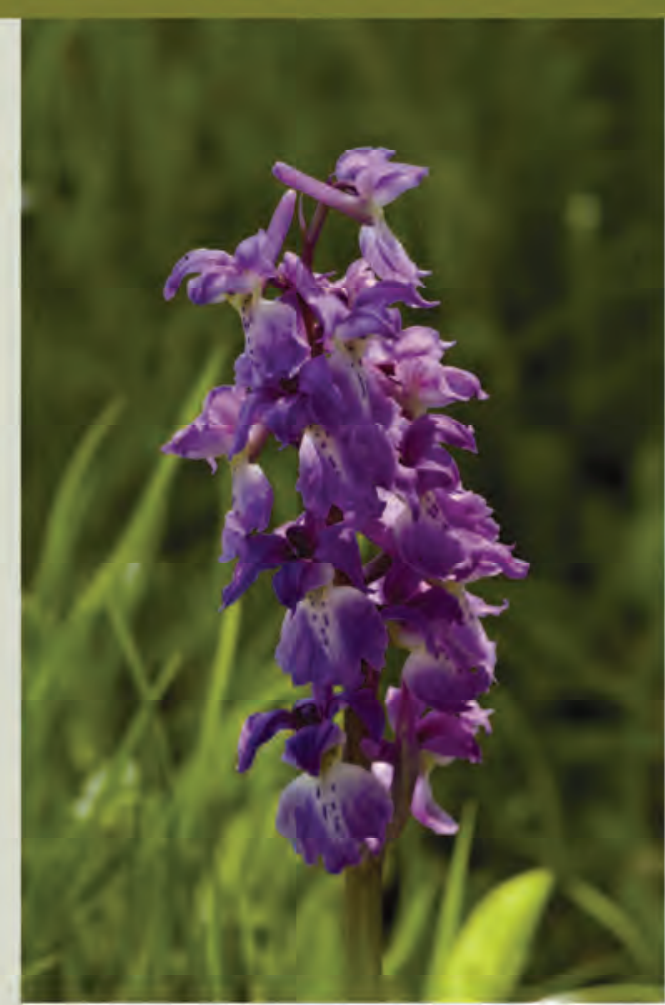

Sankt Pers nycklar är en fridlyst orkide. Bild: Henrik Pyndt Sørensen/Biofoto.

\section{Nyårshälsningen gav snabba resultat}

Odder kommun i Danmark fick ett kort med den fridlysta orkidén Sankt Pers nycklar (Orchis mascula), och en uppmaning att ta văl vara pả den. Redan tvá veckor senare gav uppmaningen resultat. Kommunen mottog senare gav uppmaningen resultat. Kommunen mottog en anmalan av en kommuninvánare om att en del av ett pả c. 300 exemplar fanns pá en myr och ăppelodling och hade spridit sig till en dikesren som skulle rensas av kommunen. Diket rensas med 5-10 árs mellanrum och det uppgrăvda materialet läggs normalt pả dikesrenen, dăr den săllsynta orkidén växer. Anmălningen fick kommunen att ăndra planen för deponering av det upprensade materialet, sả att det inte skadade orkidébeståndet. 


\section{Positiv mottagning i Danmark}

Postkortet fick en mycket positiv mottagning av alla kommundirektörer samt av lokalpressen i de olika kommunerna. Lokalpressen skrev om kampanjen i upp till tvả mảnader efteråt, och i många fall reagerade kommunerna med att genomföra olika projekt till gagn för naturen.

\section{Norges postkortskampanj}

Norge foljde Danmarks exempel och genomförde en motsvarande postkortskampanj 2008. Norges miljöminister skickade unika kort till alla $430 \mathrm{kom}-$ mundirektörer. Direktörerna blev ombedda att ta hand om den hotade arten i sin kommun. Kampanjen fick fart av ett tv-inslag, där Norges miljöminister Erik Solheim i Nesodden häller kommunenes ansvarsart, stor vattensalamander (Triturus cristatus) i sin hand. Postkortskampanjen blev positivt mottagen av bảde kommundirektörerna och pressen. Media visade stort intresse till exempel genom att en radiokanal presenterade en ansvarsart varje söndag under hela áret 2008.

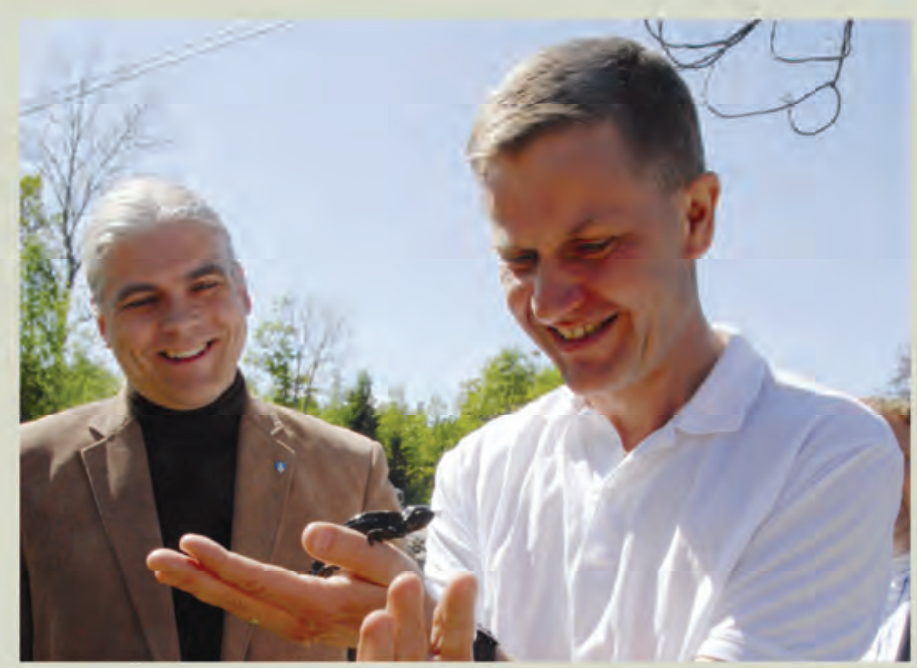

Norges miljominister Erik Solheim med en stor vattensalamander Bild: Trond Folckersahm.

\section{Flera kampanjer i framtiden}

Finland, Färöarna och Island överväger alla att följa Danmarks och Norges framgảngsrika exempel med postkortskampanjer inom snar framtid. Danmark ảteranvănde sin egen idé och i boorjan av januari 2010 skickade danska miljöministern

Troels Lund Poulsen en ny nyărshälsning till kommunerna med bilder av olika naturtyper, fôr att öka kănnedomen om hotade naturtyper.

\section{Källor:}

By-og Landskabsstyrelsen www.blst.dk

http://mww.blst.dk/Biodiversitet/Kommune2010/truede_dyr_planter/

Skov-og Naturstyrelsen wmw.sns.dk

Danmarks Miljøundersøgelser www.dmu.dk

Direktoratet for naturforvaltning www.dimat.no unw. dimat.no/kommunearter

Greve kommun, Michael Løgstrup

shøj kommun, Jørgen Johansen

Odder kommun

Arhus Stiftstidende 18 januari 2007

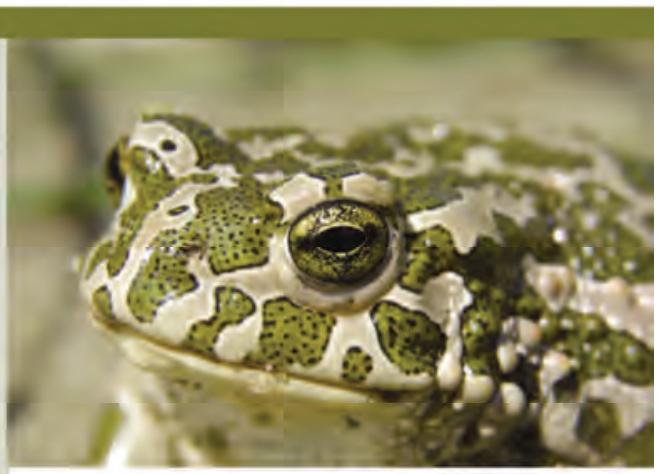

Stinkpadda. Bild: Johnny Madsen/Biofoto.

\section{Stinkpaddan på frammarsch}

Stinkpaddan (Bufo vinidis) är sällsynt i Danmark och finns bara pă enskilda platser pã öarna, som t.ex. på på ett strandnăra omráde i Greve kommun. Stinkpaddan är en värmekrävande art, som ställer speciella krav pá sina lekplatser. Paddan, sobover solexpon mar med la mar med lagt vatten, for att aggen och ynglen skall utvecklas. Igenväxning av dammar med bland annat vass är ett stort problem för paddan. För att hjälpa sin ansvarsart har Greve kommun därö̈r sammarbetat med Strandparken I/S och Danmarks naturskyddsförening. Sju dammar har restaurerats och fyra nya har grăvts sedan 2007. Resultaten har varit klara; redan första året efter den första rensningen koloniserades de nya dammarna. I en uppföljning år 2009 hittades kväkande hanar och rom i átta av elva dammar.

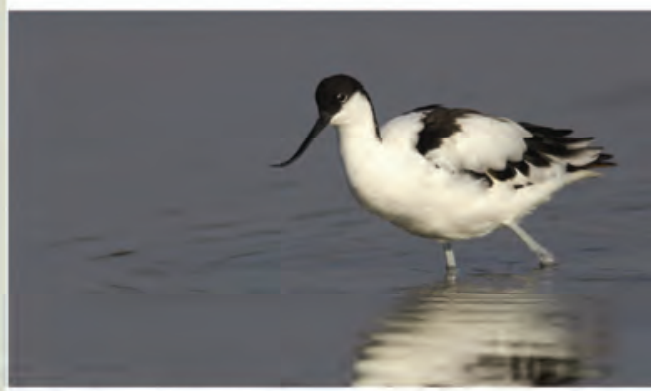

Skărflä́ckan fridlystes i Danmark ár 1922. Bild: Lars Gejl/Biofoto.

\section{Skärfläckans livsmiljö förbättrad}

Ishøj kommun blev tilldelad skärfläckan (Recurvirostra avosetta) som sin ansvarsart. Skärfläckan lever pả små ̋ar och strandängar i Strandparken. Âr 2006 fans bara tre häckande par kvar i området, så det var hög tid att göra nảgot för den karakteristiska svartvita vadaren. Ishøj kommun har fokuserat pá att förbättra skärfläckans livsmiljö i Strandparken genom att avlägsna vegetation pá flera smá ỏar. Oama har ocksả rỏjts och betats ay fắr och getter för att förmă făglarna att slă sig ner pó dem. Det ăr ändå ănnu för tidigt att avgö́ sig ner pá dem. Del ar anda a annu for tidigt att avgöra hurdan inverkan átgårdema har pả skărflăcksbestándet i
omrádet.

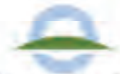

S Y K E

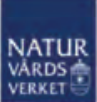

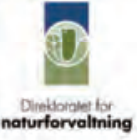

\section{MILJØMINISTERIET}

By-og Landskabsstyretsen

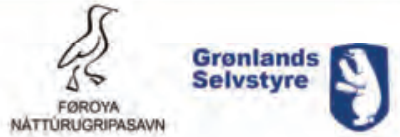

(शु) UMHVERFISSTOFNUN 


\subsection{Källor}

\section{Countdown 2010}

Källorna är listade i faktabladet.

2. FN:s konvention om biologisk mångfald

- biodiversitetskonventionen

Källorna är listade i faktabladet.

3. Ekosystemtjänster - vår framtidsförsäkring

Källorna är listade i faktabladet.

4. Fiskarternas växelverkan beaktas $i$ Norden - torsk- och sillbestånden $i$ Nordostatlanten

Källorna är listade i faktabladet.

5. Östersjöns torsk- och strömmingsbestånd - uppehåll i predator-byte förhållandet

Källorna är listade i faktabladet.

6. Havsörnens framgångsrika återkomst

Action Plan for the conservation of Whitetailed Sea Eagle (Haliaeetus albicilla). 2002. Birdlife International. Document prepared by Mr Björn Helander (Sweden) and Mr Torsten Stjernberg (Finland) on behalf of the BirdLife International Sweden.

Artdatabanken, SLU, Sverige. 2006. Faktablad: Haliaeetus albicilla havsörn.

Bakken, V., O. Runde \& E. Tjørve. 2003. Norsk Ringmerkingsatlas. Vol. 1. Stavanger Museum.

Birdlife International. 2004. BIRDS IN EUROPE - Population estimates, trends and conservation status, Cambridge, U.K., Birdlife International.

Clements, J. F. 2007. The Clement's Checklist of Birds of the World. The Cornell University Press.

Ehmsen, E \& L. Pedersen. 2006. Årsrapport for Projekt Ørn 2006, Dansk Ornitologisk Forening.

Gjershaug, J. O., P. G. Thingstad, S. Eldøy \& S.Byrkjeland. 1994. Norsk fugleatlas. Hekkefuglenes utbredelse og bestandsstatus i Norge. Norsk Ornitologisk Forening.

Hailer, Frank. 2006. Conservation Genetics of the White-Tailed Eagle. http://urn. kb.se/resolve?urn=urn:nbn:se:uu:diva6911 (2007-12-07).

Helander, B., Marquiss, M. \& Bowerman, W. (red.). 2003. SEA EAGLE 2000. Proceedings from an international Conference at Björkö, Sweden, 13-17 September 2000. Swedish Society for the Conservation of Nature/SNF \& Åtta.45 Tryckeri AB. Stockholm.
Krone O., Stjernberg T., Kenntner N., Tataruch F., Koivusaari, J. \& Nuuja I. 2006. Mortality, helminth burden and contaminant residues in white-tailed sea eagles from Finland. Ambio 35: 98-104.

Krone, O., F. Wille, N. Kenntner, D. Boertmann and F. Tataruch. 2004. "Mortality factors, environmental contaminants, and parasites of white-tailed sea eagles from Greenland." Avian Diseases 48(2): 417-424.

Stjernberg, T., Koivusaari, J., Högmander, J., Ollila, T., Keränen, S., Munsterhjelm G. \& Ekblom, H. 2007. Population size and nesting success of the white-tailed sea eagle (Haliaeetus albicilla) in Finland 2005-2006. - Linnut Vuosikirja 2006:14-19. BirdLife Suomi-Finland.

Svensson, S. Svensson , M. \& Tjernberg, M. 1999. Svensk fågelatlas. Vår fågelvärld, supplement 31, Stockholm.

Svorkmo-Lundberg, T., V. Bakken, K. Mork, J. E. Røer \& S. Sæbø. 2006. Norsk VinterfuglAtlas. Norsk Ornitologisk Forening.

7. Isbjörnen - på toppen av den arktiska näringskedjan och beroende av havsisen

Aars, J., Lunn, N. J. \& Derocher, A. E. (red.). 2006. Polar Bears: Proceedings of the $14^{\text {th }}$ Working Meeting of the IUCN/SSC Polar Bear Specialist Group, 20-24 June 2005, Seattle, Washington, USA. IUCN, Gland, Switzerland and Cambridge, UK.

Aevar Petersen. 2008, Icelandic Institute of Natural History. pers. komm.

Elmer Topp-Jørgensen. 2008. Grønlands Hjemmestyre, Direktoratet for Fiskeri, Fangst og Landbrug. pers. komm.

Fernando Ugarte. 2008. Grønlands Naturinstitut. pers. komm.

Boertmann, David. 2007. Grønlands Rødliste 2007. Greenland red list. Grønlands Hjemmestyre, Direktoratet for Miljø og Natur.

Greenland Home Rule Executive order nr 21 af $22^{\text {nd }}$ September 2005 on protection and hunting of polar bears.

Impacts of a Warming Arctic: Artic Climate Impact Assessment ACIA. 2004. Cambridge University Press. Electronic publication at http://www.acia.uaf.edu/. Jenssen, B. M. 2006. EndocrineDisrupting Chemicals and Climate 
Change: A Worst-Case Combination for Arctic Marine Mammals and Seabirds Environmental Health Perspectives 114:76-80.

Kit M. Kovacs. 2008. Norsk Polarinstutt. pers. komm.

Miljøovervåking - Svalbard og Jan Mayen (MOSJ) http://mosj.npolar.no/.

Peacock, E. 2008. Davis Strait Population Survey - Interim Report 2007. Department of Environment, Nunavut, Canada.

8. Nordens unika lantraser

Hallanaro, Eeva-Liisa \& Pylvänäinen Marja. 2002. Nature in Northern Europe - Biodiversity in a changing environment. Nord 2001:13. Nordic Council of Ministers, Copenhagen.

Heikkinen, Ilkka. (red.). 2007. Luonnon puolesta - ihmisen hyväksi. Suomen luonnon monimuotoisuuden suojelun ja kestävän käytön strategia 2006-2016. Ympäristöministeriö, Helsinki.

Lappalainen, Annikki \& Jääskeläinen, Liisa: Maatiaiskasvien ylläpito on kulttuurityötä. Artikkeli: http://www.edu.fi/ oppimateriaalit/kasvikulttuuri/ artikkelit/ 14_maatiaiskasvit.htm, 14.4.2008.

Lappalainen, Iiris. (red.). 1998. Suomen luonnon monimuotoisuus. Oy Edita Ab, Helsinki.

Suomen kansallinen kasvigeenivaraohjelma. 2007. Suomalaiset maatiaiskasvit. Forssan kirjapaino

Tiainen, J., Kuussaari, M., Laurila, I.P. Toivonen, T. (red.). 2004. Elämää pellossa - Suomen maatalous-ympäristön monimuotoisuus. Edita Publishing Oy, Helsinki.

The State of the World's Animal Genetic Resources for Food and Agriculture. 2007. Commission on Genetic Resources for Food and Agriculture. Food and Agriculture Organization of the United Nations, Rome.

9. Fåglar reagerar på klimatförändringen

Ahola, M.P., Laaksonen, T., Eeva, T. \& Lehikoinen, E. 2007. Climate change can alter competitive relationships between resident and migratory birds. Journal of Animal Ecology (2007) 76, 1045-1052. British Ecological Society.

Barrett, R.T. 2002. The phenology of spring bird migration to north Norway. Bird Study (2002) 49, 270-277.

Birdlife. 2008. "Climatic Atlas of European Breeding Birds” research by Professors Brian Huntley (Durham University) and Rhys Green (BirdLife England,
University of Cambridge) and PhDs Yvonne Collingham and Steve Willis (Durham University). Published by Lynx Publishers and BirdLifen England, BirdLife International and Durham University. European Bird Cencus Council has also collaborated.

Both, C. 2007. Comment on "Rapid Advance of Spring Arrival Dates in LongDistance Migratory Birds”. Science Vol. 315: 598.

Both C. \& te Marvelde, L. 2007. Climate change and timing of avian breeding and migration throughout Europe. Climate Research Vol 35: 93-105.

Conservation of Nordic Nature in a Changing Climate. 2005. TemaNord 2005:572. Nordic Council of Ministers. Copenhagen.

Convention on the conservation of European wildlife and natural habitats. Standing Committee. $2^{\text {nd }}$ Meeting of the Group of Experts on Biodiversity and Climate Change. Climate change and the vulnerability of Bern Convention species and habitats. Discussion paper TPVS/Inf (2008) 6. Council of Europe, Strasbourg 26 February 2008.

Framstad E. (red.). 2006. Natur i endring. Terrestrisk naturovervåking 2005: Markvegetasjon, epifytter, smågnagere og fugl. NINA Rapport 150.

Framstad E. (red.). 2007. Natur i endring. Terrestrisk naturovervåking 2006: Markvegetasjon, epifytter, smågnagere og fugl. NINA Rapport 262.

Intergovernmental Panel on Climate Change IPCC, Fourth Assessment Report. Climate Change 2007: Synthesis Report. Summary for Policymakers. Jónsson, J.E., Garðarsson, A., Gill, J.A., Petersen, Æ., Gunnarsson, T.G. 2008. Does weather influence breeding numbers and spring arrival of Common Eider in NW Iceland? Natural Science Symposium 2008, March 14th and 15th in Askja (Natural Sciences Building), University of Iceland.

Jonzén N., Lindén, A., Ergon, T., Knudsen, E., Vik, J.O., Rubolini, D., Piacentini, D., Brinch, C., Spina, F., Karlsson, L., Stervander, M., Andersson, A., Waldenström, J., Lehikoinen, A., Edvardsen, E., Solvang, R., \& Stenset, N.C. 2006. Rapid Advance of Spring Arrival Dates in LongDistance Migratory Birds. Science Vol. 312: 1959-1961. 
Jonzén, N., Lindén, A., Ergon, T., Knudsen, E., Vik, J.O., Rubolini, D., Piacentini, D., Brinch, C., Spina, F., Karlsson, L., Stervander, M., Andersson, A., Waldenström, J., Lehikoinen, A., Edvardsen, E., Solvang, R. \& Stenseth, N.C. 2007. Response to Comment on "Rapid Advance of Spring Arrival Dates in Long-Distance Migratory Birds". Science Vol. 315: 598.

Hofgaard, A. 2004. Effekter av klimaendringer på biologiske/økologiske systemer. DNs overvåkingsdata - potensial og kunnskpsressurs. NINA Oppdgragsmelding 848. 53pp.

Lehikoinen, E., Sparks, T.H., \& Zalakevicius, M. 2006. Arrival and Departure Dates. Advances in Ecological Research 35:1-31.

Ludwig, G.X. 2007. Mechanisms of Population Declines in Boreal Forest Grouse. Jyväskylä: University of Jyväskylä, 48 p. Doctoral thesis.

Ludwig, G.X., Alatalo, R.A., Helle, P, Lindén, H., Lindström, J. \& Siitari, H. 2006. Short- and long-term population dynamical consequences of asymmetric climate change in black grouse. Proc. R. Soc. B (2006) 273, 2009-2016.

Virkkala, R., Heikkinen, R. K., Leikola, N. \& Luoto, M. 2008. Projected large-scale range reductions of northern-boreal land bird species due to climate change. Biological Conservation 141 (2008) 1343-1353.

10. Främmande arter i Norden

Alien species in Finland. 2001. Ministry of the Environment. The Finnish Environment 466. Helsinki.

Alien species that threaten ecosystems, habitats or species. COP 6 Decision VI/23, The Hague, 7-19 April 2002.

CBD: major cross-cutting theme, Guiding Principles for the Implementation of Article 8 (h) (adopted by COP 6 Decision VI/23, The Hague, 7-19 April 2002) ("Guiding principles for the prevention, introduction and mitigation of impacts of alien species that threaten ecosystems, habitats or species").

European Strategy on Invasive Alien Species. 2003. T-PVS (2003) 7 revised. Convention on the conservation of European wildlife and natural habitats.

European Strategy on Invasive Alien Species. 2003. Final version. T-PVS (2003) 7 revised. Council of Europe. Strasbourg, 5 December 2003.
Gederaas, L., Salvesen, I.\& Viken, Å. (red.). 2007. Norsk svarteliste 2007 Økologiske risikovurderinger av fremmede arter. Artsdatabanken, Norge.

Global Invasive Species Programme GISP, Global Strategy on Invasive Alien Species, Toolkit of Best Prevention and Management Practises.

Hulme, Philip E. 2007. Biological Invasions in Europe: Drivers, Pressures, States, Impacts and Responses. Issues in Environmental Science and Technology, No. 25. Biodiversity Under Threat. The Royal Society of Chemistry.

Nationell strategi för främmande arter och genotyper. Delredovisning av ett regeringsuppdrag. Dnr 400-378-06 Nh. 23-062008. Naturvårdsverket. (Swedish national strategy for invasive alien species). Nielsen, C., Ravn, H.P., Nentwig, W. \& Wase, M. (red.). 2005. The Giant Hogweed Best Practice manual. Guidelines for the management and control of an invasive weed in Europe.

Weidema, I. R. (red.). 2000. Introduced Species in the Nordic Countries. Nord 2000:13. Nordic Council of Ministers, Copenhagen.

11. Kan Nordens groddjur räddas?

ArtDatabanken - The Swedish Species Information Centre: www.artdata.slu.se.

Danish Forest and Nature Agency: www.skovognatur.dk.

Finnish Museum of Natural History, University of Helsinki: www.fmnh.helsinki.fi.

Gärdenfors, U. (red.). 2005. Rödlistade arter i Sverige 2005 - The 2005 Red List of Swedish Species. ArtDatabanken, SLU, Uppsala.

Hallanaro, Eeva-Liisa \& Pylvänäinen Marja. 2002. Nature in Northern Europe - Biodiversity in a changing environment. Nord 2001:13. Nordic Council of Ministers, Copenhagen.

IUCN SSC Invasive Species Specialist Group: www.issg.org.

National Environmental Research Institute NERI: www.dmu.dk, The Danish Red Data Book

Naturvårdsverket. 2007. Åtgärdsprogram för bevarande av större vattensalamander och dess livsmiljöer. Rapport 5636. Naturvårdsverket, Stockholm.

Norwegian Biodiversity Information Centre: www.artsdatabanken.no, Red List Database. 
Norwegian Directorate for Nature Management: www.dirnat.no.

Norwegian Directorate for Nature Management. 2006. Handlingsplan for damfrosk Rana lessonae (Norwegian action plan for the pool frog Rana lessonae). DN rapport 2006-2.

Overvågning af løvfrølokaliteter mellem Vejle og Kolding 2004, Udarbejdet af Aqua Consult for Vejle Amt - Teknik og miljø (Report of monitoring of tree frog localities between Vejle and Kolding, Denmark).

Pounds, J. Alan et al. 2006. Widespread amphibian extinctions from epidemic disease driven by global warming. Nature Vol 439/12 January 2006, s. 161-167.

Scalera, Richard, Adams, Michael J., Galvan, Stephanie K. 2008. Occurrence of Batrachochytrium dendrobatidis in Amphibian Populations in Denmark. Herpetological Review 39(2), 2008, s. 199-200.

Vuorio Ville: Rupiliskon suojelusuunnitelma, Luonnos. 2008. PohjoisKarjalan ympäristökeskus.

World Association of Zoos and Aquariums (WAZA), the IUCN/SSC Conservation Breeding Specialist Group (CBSG), and the IUCN/SSC Amphibian Specialist Group (ASG): www.amphibianark.org.

12. Mot hållbart bruk av ren-och fårbetesmarker i Norden

Arnalds, O. and B.H. Barkarson. 2003. Soil Erosion and Land Use Policy in Iceland in Relation to Sheep Grazing and Government Subsidies. Environmental Science and Policy, Vol 6, s. 105-113.

Arnalds, O., E.F. Thorarinsdottir, S. Metusalemsson, A. Jonsson, E. Gretarsson and A. Arnason. 2001. Soil Erosion in Iceland. Soil Conservation Service, Agricultural Research Institute, Reykjavík, Iceland.

Artsdatabanken, Norge. Fjellet - Miljøforhold og påvirkninger på rødlistearter.

Eskelinen, Anu \& Oksanen, Jari. Changes in the abundance, composition and species richness of mountain vegetation in relation to summer grazing by reindeer. 2006. In Journal of Vegetation Science 17:245-254, 2006. IAVS: Opulus Press Uppsala.

Esselin, Anders. 2003. Storskaligt överbete i fjällen - en myt. Fjällfokus nr. 11. FjällMistra, Umeå.

Hallanaro, Eeva-Liisa \& Pylvänäinen Marja. 2002. Nature in Northern Europe
- Biodiversity in a changing environment. Nord 2001:13. Nordic Council of Ministers, Copenhagen.

Johansen, Bernt E. \& Karlsen, Stein Rune, Norut as. 2007. Finnmarksvidda - kartlegging og overvåking av reinbeiter. Status 2006.

Kumpula J. et al. 2006. Porolaidunten inventoinnin kehittäminen - Keski-Lapin paliskuntien laiduninventointi vuosina 20052006. Kala- ja riistaraportteja nro 397. Riistan- ja kalantutkimus, Kaamanen.

Linkowski, Weronika I. \& Lennartsson Tommy. 2006. Renbete och biologisk mångfald. Kunskapssammanställning. Rapportserie Nummer 18/2006. Länsstyrelsen i Norrbottens län, Luleå.

Mattila, Eero. 2006. Porojen talvilaitumien kunto poronhoitoalueen etelä- ja keskiosien merkkipiireissä 2002-2004 ja kehitys 1970-luvun puolivälistä alkaen. Metlan työraportteja 27. Metsäntutkimuslaitos Metla.

At læse landskabet - Bæredygtig græsning af udmarker. 2007. TemaNord 2006:586. Nordisk Ministerråd, København.

13. Framgångsrik restaurering och vård av inlandsvatten i Norden

Holopainen, I. \& Karjalainen, H. 2004. Järvet. I: M. Walls \& M. Rönkä (red.). Veden varassa. Suomen vesiluonnon monimuotoisuus. s. 30-43. Edita Publishing Oy. Helsinki.

Ulvi, T. \& Lakso E. (red.). 2004. Järvien kunnostus. Suomen ympäristökeskus. Edita Publishing Oy, Helsinki.

Wahlström, E., Hallanaro, E-L \& Manninen, S. 1996. Miljöns framtid i Finland. Edita. Finlands miljöcentral, Helsingfors. Nordens miljö - tillstånd, utveckling och hot. 1993. Monitor 13. Naturvårdsverket, Solna.

Puhdas Vesijärvi 2008. Päijät-Hämeen Vesijärvisäätiö.

Tuominen Lasse \& Kolunen Heikki. 1992. Vesijärvi. Luontoa - tutkimusta - maisemia. Lahden kaupungin ympäristönsuojelutoimisto.

Vuorenmaa, Jussi. 2007. Recovery responses of acidified Finnish lakes under declining acid deposition. Monographs of the Boreal Environment Research no. 30, 2007. (doctoral thesis).

Arktisk miljö i Norden - orörd, exploaterad, förorenad? 1996. Nord 1996:21. Nordiska ministerrådet, Köpenhamn. Søndergaard, M., Jeppesen, E. \& Jensen, J. P. 1999. Danske søer og deres restaure- 
ring. TEMA-rapport fra DMU 24/1999. Miljø- og Energiministeriet, Danmarks Miljøundersøgelser.

Kalkning av sjöar och vattendrag. 2002. Handbok 2002:1. Naturvårdsverket. Startpage > Arbete med naturvård > Skydd och skötsel av värdefull natur $>$ Sjöar och vattendrag > Kalkning av sjöar och vattendrag.

Kalking i laksevassdrag. Effektkontroll 2007. Regionale og vassdragsvise utviklingstrekk. Notat 2008-3. Direktoratet for naturforvaltning.

14. Lokal medverkan för att hejda förlusten av biologisk mångfald

Källorna är listade i faktabladet.

15. Nordens ängs- och betesmarker hotade

Alanen A. 1997. Maaseudun mansikkapaikat - muistojako vain? I: Turunen, S., Uotila, P., Syrjämäki, J., Koponen, T. \& Walls, M. (red.). 1997. Suomen luonnon sata vuotta. Suomen Biologian Seura Vanamo ry. Helsinki. S. 197-208.

Edman, Staffan \& Hagman, Tore. 1988. Bondens landskap Naturskyddsföreningens årsbok 1988.

Fellestad, W., Nordenhaug, A. \& Ødegaard, F. 2008. Tidligere och nåværende jordbruksareal - miljøforhold og påvirkninger på rødlistearter. Artsdatabanken, Norge.

Nielsen, Lisbeth, Hald, Anna Bodil \& Buttenschøn, Rita Merete. 2006. Beskyttede ferske enge: Vegetation, påvirkninger, pleje, naturplanlægning. Skov- og Naturstyrelsen.

Nordic Council of Ministers. 2004. Fögur er hlíðin - Fair is the blooming meadow. A Study of Traditional Nordic and Baltic rural landscapes and biotopes and their survival in modern times. TemaNord 2004:564. Nordic Council of Ministers, Copenhagen.

Naturvårdsverket. 1997. Ängs- och hagmarker i Sverige. Ancient Meadows and Pastures in Sweden. Rapport 4819.

Pajari, Mika. 2002. Suomen uhanalaisia lajeja: Muurahaissinisiipi (Maculinea arion). Suomen ympäristö 549. Suomen ympäristökeskus, Helsinki.

Perinnemaisemien hoitotyöryhmän mietintö. 2000. Perinnebiotooppien hoito Suomessa. Suomen ympäristö SY443. Suomen ympäristökeskus, Helsinki.

Priha, Marjo (red.). 2003. Perinnebiotooppien hoitokortit. 1 - Laidunnus/1 - Bete, 2 - Niitto/2 - Slåtter, 5 - Hoidon suunnittelu/Planering av vårdbiotopernas skötsel, 6 - Tuoreet niityt ja kedot/Friska och torra ängar, 7 - Hakamaat ja metsälaitumet/Hagmarker och skogsbeten.

Pykälä, J. 2001. Perinteinen karjatalous luonnon monimuotoisuuden ylläpitäjänä. Suomen ympäristö SY495. Suomen ympäristökeskus, Helsinki.

Raunio, A., Schulman A. ja Kontula T. (red.). 2008. Suomen luontotyyppien uhanalaisuus. (Hotbedömningen av Finlands naturtyper). Suomen ympäristökeskus, Helsinki. Suomen ympäristö 8/2008. Delar I \& II.

Stoltze, Michael - Danske dagsommerfugle. Gyldendal 1996. Møns Klint og Klintholm. Vandreture nr. 53. Miljøministeriet. Skov- og Naturstyrelsen.

Tiainen, J., Kuussaari, M., Laurila, I. P. \& Toivonen, H. (red.). 2004. Elämää pellossa - Suomen maatalous-ympäristön monimuotoisuus. Edita Publishing Oy, Helsinki. 366 s. Osa 4. Perinnebiotoopit. Osa 5. Maatalousympäristön hoito.

16. 100-årsjubileum för europeiska nationalparker

Nordiska ministerrådet. 1995. Nordisk naturvård - möjligheter och problem. TemaNord 1995:501. Nordiska ministerrådet, Köpenhamn.

Arktisk miljö i Norden - orörd, exploaterad, förorenad? 1996. Nord 1996:21. Nordiska ministerrådet, Köpenhamn.

Hallanaro, Eeva-Liisa \& Pylvänäinen Marja. 2002. Nature in Northern Europe - Biodiversity in a changing environment. Nord 2001:13. Nordic Council of Ministers, Copenhagen.

Naturvårdsverket. 2001. Nationalparkerna i Sverige. Rapport 1218. Naturvårdsverket, Stockholm.

Naturvårdsverket. 2008. Nationalparksplan för Sverige. Långsiktig plan. Rapport 1269. Naturvårdsverket, Stockholm.

17. Hot mot biodiversiteten i Norden Boertmann, David. 2007. Grønlands Rødliste 2007. Greenland red list. Grønlands Hjemmestyre, Direktoratet for Miljø og Natur.

Gärdenfors U. (red.). 2005. Rödlistade arter i Sverige 2005 - The 2005 Red List of Swedish Species. ArtDatabanken, SLU, Uppsala.

Hallanaro, Eeva-Liisa \& Pylvänäinen Marja. 2002. Nature in Northern Europe - Biodiversity in a changing environment. Nord 2001:13. Nordic Council of Ministers, Copenhagen. 
Kålås, J.A., Viken, Å. \& Bakken, T. (red.). 2006. Norsk Rødliste 2006 - 2006 Norwegian Red List. Artsdatabanken, Norge.

Nordens natur - trender mot 2010 -projektets faktablad på internet www.miljo.fi/nordensnatur

Normander Bo et al. 2009. State of biodiversity in the Nordic Countries. An assessment of progress towards achieving the target of halting biodiversity loss by 2010. TemaNord 2009:509. Nordic Council of Ministers, Copenhagen 2008. Rassi, P., Alanen, A., Kanerva, T. \& Mannerkoski, I. (red.). 2001. Suomen lajien uhanalaisuus 2000. (Rödlistade arter i Finland). Ympäristöministeriö \& Suomen ympäristökeskus, Helsinki.

Raunio, A., Schulman, A. \& Kontula, T. (red.). 2008. Suomen luontotyyppien uhanalaisuus - Osa 1. Tulokset ja arvioinnin perusteet (Hotbedömningen av Finlands naturtyper - Del 1: Resultat och hotbedöminingens grunder) - Suomen ympäristö 8:2008.

Raunio, A., Schulman, A. \& Kontula, T. (red.). 2008. Suomen luontotyyppien uhanalaisuus - Osa 2: Luontotyyppien kuvaukset (Hotbedömningen av Finlands naturtyper - Del 2: Beskrivningar av naturtyper) - Suomen ympäristö 8:2008.

Stoltze, M. \& Pihl, S. (red.). 1998. Rødliste 1997 over planter og dyr i Danmark. The Danish Red List 1997. Miljø- og Energiministeriet, Danmarks Miljø-undersøgelser og Skov- og Naturstyrelsen.

18. Sandsträndernas rika liv hotas

Agerlund, S. \& Vestergaard, P. 2007. Forsøg med opgravning af rynket rose i klitterræn. I: Weidema, I. et al. (red.). Rynket rose (Rosa rugosa) i Danmark. Rapport fra workshop på Biologisk Institut, Københavns Universitet, 5-6 september 2006. Biologisk Institut, Køben- havns Universitet, Skov og Landskab, Københavns Universitet, Skov- og Naturstyrelsen, pp. 72-74.

Dalsgarð J., Fosaa A.M. \& Gaard E. (red.). 2006. Føroya Náttúra, 2006. Føroya Skúlabókagrunnur, Tórshavn. Direktoratet for naturforvaltning. 2007. Kartlegging av naturtyper - verdisetting av biologisk mangfold. Håndbok 13, 2. edition 2006.

Hallanaro, Eeva-Liisa \& Pylvänäinen Marja. 2002. Nature in Northern Europe - Biodiversity in a changing environment. Nord 2001:13. Nordic Council of Ministers, Copenhagen.

Kekäläinen, H., Keynäs, K., Koskela, K., von Numers, M., Rinkineva-Kantola L., Ryttäri, T. \& Syrjänen, K. 2008. Itämeren rantaluontotyypit. I: Raunio, A., Schulman, A. \& Kontula, T. (red.). 2008. Suomen luontotyyppien uhanalaisuus Osa 2: Luontotyyppien kuvaukset (Hotbedömningen av Finlands naturtyper Del 2: Beskrivningar av naturtyper). Suomen ympäristö 8:2008. S. 35-88.

Kustbiotoper i Norden. 2001. Hotade och representativa biotoper. Nord 2001:536. Nordiska Ministerrådet, Köpenhamn.

Miljø- og Energiministeriet, Skov- og Naturstyrelsen. 1999. Skov- og Naturstyrelsens naturplejestartegi.

Miljøministeriet, Skov- og Naturstyrelsen, Danmarks Naturfredningsforening, Friluftsrådet. 2004. Beskyt den vilde flora ved kysterne. Rynket Rose og andre indførte planter udrydder oprindelige og værdifulde plantesamfund.

Miljøministeriet, Skov- og Naturstyrelsen. 2009. Skov og natur i tal 2009.

Olsen, Søren. 2000. Danmarks natur. Guide til 166 naturseværdigheder. Politikens forlag A/S.

19. Postkort om kommunernas ansvarsarter Källorna är listade i faktabladet. 



\section{Bilagor I}

Tabell 1: Nordens groddjursarter. Bilaga till faktablad 11. Kan Nordens groddjur räddas?

\begin{tabular}{|c|c|c|c|c|c|c|c|c|c|}
\hline & Finland & & Sverige & & Norge & & Danmark & & \\
\hline Bufo bufo & rupikonna & LC & padda & LC & padde & LC & skrubtudse & LC & $\begin{array}{l}\text { common toad/ } \\
\text { european toad }\end{array}$ \\
\hline $\begin{array}{l}\text { Bufo } \\
\text { calamita }\end{array}$ & haisukonna & - & stinkpadda & EN & strandpadde & - & strandtudse & LC & natterjack toad \\
\hline $\begin{array}{l}\text { Bufo } \\
\text { viridis }\end{array}$ & viherkonna & - & $\begin{array}{l}\text { grönfläckig } \\
\text { padda }\end{array}$ & $\mathrm{CR}$ & $\begin{array}{l}\text { grønnflekket } \\
\text { padde }\end{array}$ & - & $\begin{array}{l}\text { grønbroget } \\
\text { tudse }\end{array}$ & LC & $\begin{array}{l}\text { european } \\
\text { green toad }\end{array}$ \\
\hline $\begin{array}{l}\text { Bombina } \\
\text { bombina }\end{array}$ & $\begin{array}{l}\text { kellosam- } \\
\text { makko }\end{array}$ & - & klockgroda & NT & klokkefrosk & - & klokkefrø & NT & $\begin{array}{l}\text { european fire- } \\
\text { bellied toad }\end{array}$ \\
\hline $\begin{array}{l}\text { Hyla } \\
\text { arborea }\end{array}$ & $\begin{array}{l}\text { euroopanleh- } \\
\text { tisammakko }\end{array}$ & - & lövgroda & LC & løvfrosk & - & løvfrø & LC & $\begin{array}{l}\text { european tree } \\
\text { frog }\end{array}$ \\
\hline $\begin{array}{l}\text { Pelobates } \\
\text { fuscus }\end{array}$ & $\begin{array}{l}\text { kaivajasam- } \\
\text { makko }\end{array}$ & - & lökgroda & NT & løkfrosk & - & løgfrø & $\mathrm{DD}$ & $\begin{array}{l}\text { spadefoot } \\
\text { toad/common } \\
\text { spadefoot }\end{array}$ \\
\hline $\begin{array}{l}\text { Rana } \\
\text { tempora- } \\
\text { ria }\end{array}$ & sammakko & LC & vanlig groda & LC & buttsnutefrosk & LC & $\begin{array}{l}\text { butsnudet } \\
\text { frø }\end{array}$ & LC & $\begin{array}{l}\text { common frog/ } \\
\text { european } \\
\text { common frog/ } \\
\text { european com- } \\
\text { mon brown frog }\end{array}$ \\
\hline $\begin{array}{l}\text { Rana } \\
\text { arvalis }\end{array}$ & viitasammakko & LC & åkergroda & LC & spissnutefrosk & NT & $\begin{array}{l}\text { spidssnudet } \\
\text { frø }\end{array}$ & LC & moor frog \\
\hline $\begin{array}{l}\text { Rana } \\
\text { dalmatina }\end{array}$ & $\begin{array}{l}\text { hyppysam- } \\
\text { makko }\end{array}$ & - & $\begin{array}{l}\text { långbens- } \\
\text { groda }\end{array}$ & VU & springfrosk & - & springfrø & LC & agile frog \\
\hline $\begin{array}{l}\text { Rana } \\
\text { lessonae }\end{array}$ & $\begin{array}{l}\text { lessonan- } \\
\text { sammakko }\end{array}$ & - & gölgroda & VU & damfrosk & $\mathrm{CR}$ & & - & pool frog \\
\hline $\begin{array}{l}\text { Rana } \\
\text { ridibunda }\end{array}$ & $\begin{array}{l}\text { mölysam- } \\
\text { makko }\end{array}$ & $\begin{array}{l}\text { Till- } \\
\text { fällig }\end{array}$ & sjögroda & - & latterfrosk & - & latterfrø & $\mathrm{DD}$ & marsh frog \\
\hline $\begin{array}{l}\text { Rana } \\
\text { esculenta }\end{array}$ & $\begin{array}{l}\text { vihersam- } \\
\text { makko }\end{array}$ & - & ätlig groda & LC & hybridfrosk & - & grøn frø & LC & $\begin{array}{l}\text { common water } \\
\text { frog/green frog/ } \\
\text { edible frog }\end{array}$ \\
\hline $\begin{array}{l}\text { Triturus } \\
\text { cristatus }\end{array}$ & rupilisko & Vu & $\begin{array}{l}\text { större vatten- } \\
\text { salamander }\end{array}$ & LC & $\begin{array}{l}\text { stor } \\
\text { salamander }\end{array}$ & Vu & $\begin{array}{l}\text { stor vandsa- } \\
\text { lamander }\end{array}$ & LC & $\begin{array}{l}\text { great crested } \\
\text { newt }\end{array}$ \\
\hline $\begin{array}{l}\text { Triturus } \\
\text { vulgaris }\end{array}$ & vesilisko & LC & $\begin{array}{l}\text { mindre } \\
\text { vattensala- } \\
\text { mander }\end{array}$ & LC & $\begin{array}{l}\text { liten } \\
\text { salamander }\end{array}$ & NT & $\begin{array}{l}\text { lille vandsa- } \\
\text { lamander }\end{array}$ & LC & smooth newt \\
\hline $\begin{array}{l}\text { Triturus } \\
\text { alpestris }\end{array}$ & alppivesilisko & - & $\begin{array}{l}\text { bergvattensa- } \\
\text { lamander }\end{array}$ & - & $\begin{array}{l}\text { bergsala- } \\
\text { mander }\end{array}$ & - & $\begin{array}{l}\text { bjergsala- } \\
\text { mander }\end{array}$ & LC & alpine newt \\
\hline
\end{tabular}

$\mathrm{CR}=$ akut hotad, $\mathrm{EN}=$ starkt hotad, $\mathrm{VU}=$ sårbar, NT = missgynnad, $\mathrm{LC}=$ livskraftig, $\mathrm{DD}=$ britsfällig kunskap

Till utrotningshotade räknas klasserna CR, EN och VU

Alla groddjur är fridlysta i Finland, Sverige, Norge och Danmark

Sources:

Finland: Rassi,P., Alanen, A., Kanerva, T. \& Mannerkoski, I. (red.) 2001. Suomen lajien uhanalaisuus 2000. Miljöministeriet \& Finlands miljöcentral. Helsingfors

Sverige: Gärdenfors, U. (red.) 2005. Rödlistade arter i Sverige. ArtDatabanken. SLU. Uppsala.

Norge: Kålås, J.A., Viken, Å. \& Bakken, T. (red.) 2006. Norsk Rødliste 2006. Artsdatabanken. Norge.

Danmark: Den danske rødliste/Fagdatacenter for Biodiversitet og Terrestrisk Natur (B-FDC). Danmarks Miljøundersøgelser 2004, [http://redlist.dmu.dk]

Tablellen sammanställd av projektet Nordens natur - trender mot 2010, för faktabladet "Kan Nordens groddjur räddas?"

[www.miljo.fi/nordensnatur] > Faktablad > Nordens groddjur. Publiserad 11.12.2008. 
Tabell 2: Hotade arter i kulturlandskapet. Bilaga till faktablad 15. Nordens ängs- och betesmarker hotade

\begin{tabular}{|c|c|c|c|c|c|c|c|}
\hline & & \multicolumn{3}{|c|}{ Finland } & \multicolumn{3}{|c|}{ Sverige } \\
\hline & & Kulturlandsk. & totalt & $\%$ & kulturlandsk. & totalt & $\%$ \\
\hline Alger & Algae $^{1}$ & 0 & 6 & 0 & 6 & 34 & 18 \\
\hline Mossor & $\begin{array}{l}\text { Bryophyta, } \\
\text { Marchantiophyta, } \\
\text { Anthocerophyta }\end{array}$ & 0 & 136 & 0 & 60 & 220 & 27 \\
\hline Kärlväxter & Tracheophyta & 50 & 180 & 28 & 329 & 485 & 68 \\
\hline Svampar & Fungi ${ }^{2}$ & 80 & 649 & 12 & 198 & 632 & 31 \\
\hline Lavar & Lichenes & 10 & 99 & 10 & 120 & 254 & 47 \\
\hline Grod- och kräldjur & Amphibia, Reptilia & 1 & 3 & 33 & 6 & 9 & 67 \\
\hline Fåglar & Aves & 4 & 32 & 13 & 35 & 91 & 38 \\
\hline Däggdjur & Mammalia & 1 & 7 & 14 & 7 & 19 & 37 \\
\hline Ringmaskar & Annelida $^{3}$ & 320 & 759 & 42 & 2 & 2 & 100 \\
\hline Blötdjur & Mollusca & 0 & 11 & 0 & 5 & 130 & 4 \\
\hline Spindeldjur & Arachnida $^{4}$ & 1 & 12 & 8 & 22 & 71 & 31 \\
\hline Kräftdjur & Crustacea & 0 & 0 & 0 & 5 & 46 & 11 \\
\hline Sländor & $\begin{array}{l}\text { Ephemeroptera, Odo- } \\
\text { nata, Plecoptera, Neu- } \\
\text { roptera, Trichoptera }^{5}\end{array}$ & 0 & 14 & 0 & 3 & 50 & 6 \\
\hline Mångfotingar & Myriapoda $^{6}$ & 1 & 4 & 25 & 2 & 14 & 14 \\
\hline Rätvingar & Orthoptera $^{7}$ & 2 & 4 & 50 & 4 & 5 & 80 \\
\hline Halvvingar & Hemiptera $^{8}$ & 25 & 44 & 57 & 30 & 52 & 58 \\
\hline Fjärilar & Lepidoptera & 137 & 241 & 57 & 250 & 379 & 66 \\
\hline Tvåvingar & Diptera & 2 & 12 & 17 & 59 & 165 & 36 \\
\hline Steklar & Hymenoptera & 48 & 68 & 71 & 135 & 184 & 73 \\
\hline Skalbaggar & Coleoptera & 104 & 347 & 30 & 505 & 848 & 60 \\
\hline
\end{tabular}

kulturlandsk. - antalet hotade arter med huvudsaklig livsmiljö i kulturlandskapet per artgrupp SE: antalet hotade arter som förekommer i kulturlandskapet

totalt - totala antalet hotade arter per artgrupp

$\%$ - andelen hotade arter per artgrupp, med kulturlandskapet som huvudsaklig livsmiljö

- - uppgifter saknas

FI: torrängar, friska ängar, hagmark och hamlingsängar osv., fuktiga ängar och dikesrenar, diken, odlingsmark, parker, gårdar och trädgårdar, ruderata områden, byggnader.

SE: odlingsmark, trädbärande hagmarker, alléer i jordbruksbygd, slottsparker, gårdsmiljöer, alvar, ljunghedar, märgelgravar, dammar och smärre betade kärr i jordbrukslandskapet.

NO: jordbruklandskap samt tillhörande infrastruktur så som vägar, byggnader osv.

DK: ängar och allmänningar. 


\begin{tabular}{|c|c|c|c|c|c|c|c|}
\hline & & \multicolumn{3}{|c|}{ Norge } & \multicolumn{3}{|c|}{ Danmark } \\
\hline & & kulturlandsk. & totalt & $\%$ & kulturlandsk.. & totalt & $\%$ \\
\hline Alger & Algae $^{1}$ & 0 & 62 & 0 & - & - & - \\
\hline Mossor & $\begin{array}{l}\text { Bryophyta, } \\
\text { Marchantiophyta, } \\
\text { Anthocerophyta }\end{array}$ & 60 & 267 & 22 & - & - & - \\
\hline Kärlväxter & Tracheophyta & 185 & 569 & 33 & 37 & 102 & 36 \\
\hline Svampar & Fungi $^{2}$ & 217 & 880 & 25 & 81 & 405 & 20 \\
\hline Lavar & Lichenes & 83 & 269 & 31 & 9 & 316 & 3 \\
\hline Grod- och kräldjur & Amphibia, Reptilia & 4 & 17 & 24 & 2 & 5 & 40 \\
\hline Fåglar & Aves & 25 & 138 & 18 & 3 & 29 & 10 \\
\hline Däggdjur & Mammalia & 10 & 47 & 21 & 0 & 11 & 0 \\
\hline Ringmaskar & Annelida $^{3}$ & 0 & 0 & 0 & - & - & - \\
\hline Blötdjur & Mollusca & 0 & 48 & 0 & - & - & - \\
\hline Spindeldjur & Arachnida $^{4}$ & 44 & 112 & 39 & - & - & - \\
\hline Kräftdjur & Crustacea & 0 & 43 & 0 & - & - & - \\
\hline Sländor & $\begin{array}{l}\text { Ephemeroptera, Odo- } \\
\text { nata, Plecoptera, Neu- } \\
\text { roptera, Trichoptera }^{5}\end{array}$ & 1 & 100 & 1 & 0 & 43 & 0 \\
\hline Mångfotingar & Myriapoda $^{6}$ & 4 & 20 & 20 & - & - & - \\
\hline Rätvingar & Orthoptera $^{7}$ & 3 & 6 & 50 & - & - & - \\
\hline Halvvingar & Hemiptera ${ }^{8}$ & 43 & 112 & 38 & 5 & 9 & 56 \\
\hline Fjärilar & Lepidoptera & 266 & 567 & 47 & 39 & 87 & 45 \\
\hline Tvåvingar & Diptera & 49 & 289 & 17 & 12 & 35 & 34 \\
\hline Steklar & Hymenoptera & 37 & 147 & 25 & - & - & - \\
\hline Skalbaggar & Coleoptera & 298 & 995 & 30 & 138 & 561 & 25 \\
\hline
\end{tabular}

${ }^{1}$ FI: makroalger, SE: Nostocophycaeae, Phaeophycaeae, Rhodophyta, Charophycaeae, NO: Cyanophyta, Rhodophyta, Phaeophycaeae, Ulvophycaeae, Charophycaeae ${ }^{2} \mathrm{SE}$ : Makrofungi ${ }^{3} \mathrm{SE}$ : Hirudinea, Tricladida ${ }^{4} \mathrm{NO}$ : Araneae ${ }^{5} \mathrm{FI}:+$ Mecoptera, NO: + Mecoptera, Raphidioptera, Megaloptera ${ }^{6} \mathrm{Fl}$ : Chilopoda, Diplopoda ${ }^{7} \mathrm{NO}$ : + Blattodea, Dermaptera ${ }^{8}$ DK: Pentatomoidea, Coreoidea

Källor:

FI: Rassi, P., Alanen, A., Kanerva, T. \& Mannerkoski, I. (red.) 2001: Suomen lajien uhanalaisuus 2000 (Rödlistade arter i Finland 2000). - Miljöministeriet \& Finlands miljöcentral, Helsingfors.

SE: Artdatabanken, [www.artdata.slu.se/rodlista/index.cfm], 25.3.2009

NO: Kålås, J.A., Viken, A.. og Bakken, T. (red.) 2006: Norsk rødliste 2006. Artsdatabanken, Norge.

DK: Stoltze, M. og Pihl, S. (red.) 1998: Rødliste 1997 over planter og dyr i Danmark. Miljø- og Energiministeriet,

Danmarks Miljøundersögelser og Skov- og Naturstyrelsen.

Tabellen är sammanställd inom projektet Nordens natur - trender mot 2010, för faktabladet Nordens ängs- och betesmarker hotade.

[www.miljo.fi/nordensnatur] > Faktablad > Ängs- och betesmarker hotade. Publicerad 15.6.2009.

Tabell 3: Nationalparker i Norden. Bilaga till faktablad 16. 100-årsjubileum för europeiska nationalparker

Grundade nationalparker

\begin{tabular}{lr}
\hline Finland & 35 \\
Sverige & 29 \\
Norge & 31 \\
Svalbard & 7 \\
Danmark & 2 \\
Grönland & 1 (världens största) \\
Färöarna & - (första planeras) \\
Island & 3 \\
\hline
\end{tabular}

Källor:

World Database on Protected Areas [www.wdpa.org]

Metsähallitus, Finland, [www.utinaturen.fi]

Naturvårdsverket, Sverige, [www.naturvardsverket.se/nationalparker]

Direktoratet for Naturforvaltning, Norge, [www.dirnat.no/nasjonalparker]

Skov- og Naturstyrelsen, Danmark, nationalparker.skovognatur.dk. 



\section{Bilagor II}

Tabell 4: Nordens artantal och antal hotade arter

\begin{tabular}{|c|c|c|c|c|c|c|c|}
\hline & Finland & Sverige & Norge & Danmark & Island & Färöarna & Grönland \\
\hline \multicolumn{8}{|l|}{ Däggdjur } \\
\hline $\operatorname{artantal}^{1}$ & 65 & 62 & 89 & 50 & 26 & $?$ & 30 \\
\hline bedömda ${ }^{2}$ & 58 & 62 & 75 & $?$ & $?$ & $?$ & 37 \\
\hline hotade $^{3}$ & 7 & 11 & 12 & $?$ & $?$ & $?$ & 10 \\
\hline \multicolumn{8}{|l|}{ Fåglar ${ }^{4}$} \\
\hline artantal & 240 & 251 & 248 & 200 & 76 & 54 & 58 \\
\hline bedömda & 229 & 251 & 230 & $?$ & 76 & 54 & 65 \\
\hline hotade & 32 & 43 & 37 & $?$ & 32 & 29 & 9 \\
\hline \multicolumn{8}{|c|}{ Grod- och kräldjur } \\
\hline artantal & 10 & 19 & 12 & 21 & 0 & 0 & 0 \\
\hline bedömda & 10 & 19 & 11 & $?$ & - & - & - \\
\hline hotade & 3 & 6 & 2 & $?$ & - & - & - \\
\hline \multicolumn{8}{|l|}{ Fiskar } \\
\hline artantal & 68 & 141 & 289 & 258 & 300 & 247 & c. 150 \\
\hline bedömda & 68 & 141 & 208 & $?$ & $?$ & 0 & 3 \\
\hline hotade & 8 & 18 & 10 & $?$ & $?$ & - & 1 \\
\hline \multicolumn{8}{|l|}{ Insekter } \\
\hline artantal & 19846 & 23679 & 20945 & 18000 & 1268 & 1016 & 375 \\
\hline bedömda & 9786 & 10003 & 8702 & $?$ & $?$ & 0 & 5 \\
\hline hotade & 731 & 689 & 912 & $?$ & $?$ & - & 0 \\
\hline \multicolumn{8}{|l|}{ Spindeldjur } \\
\hline artantal & 2500 & 1790 & 1637 & $?$ & 96 & 212 & 192 \\
\hline bedömda & 39 & 740 & 584 & $?$ & $?$ & 0 & 0 \\
\hline hotade & 12 & 16 & 68 & $?$ & $?$ & - & - \\
\hline \multicolumn{8}{|l|}{ Blötdjur } \\
\hline artantal & 161 & 608 & 874 & 326 & C. 450 & $>380$ & 283 \\
\hline bedömda & 153 & 490 & 622 & $?$ & $?$ & 0 & 0 \\
\hline hotade & 11 & 41 & 15 & $?$ & $?$ & - & - \\
\hline \multicolumn{8}{|c|}{$\begin{array}{l}\text { Andra ryggrad } \\
\text { slösa djur }\end{array}$} \\
\hline artantal & 983 & 1731 & $?$ & $?$ & 1500 & $?$ & c. 1784 \\
\hline bedömda & 459 & 301 & $?$ & $?$ & $?$ & $?$ & 0 \\
\hline hotade & 9 & 30 & $?$ & $?$ & $?$ & $?$ & - \\
\hline \multicolumn{8}{|l|}{ Kärlväxter ${ }^{5}$} \\
\hline artantal & $\begin{array}{r}\text { c. } 2000 / \\
>1200\end{array}$ & 1638 & 2,834 & 1 050/430 & 485 & 401 & 515 \\
\hline bedömda & 1240 & 1628 & 1360 & $?$ & 485 & 0 & 5 \\
\hline hotade & 180 & 261 & 217 & $?$ & 52 & - & 1 \\
\hline
\end{tabular}




\begin{tabular}{|c|c|c|c|c|c|c|c|}
\hline & Finland & Sverige & Norge & Danmark & Island & Färöarna & Grönland \\
\hline \multicolumn{8}{|l|}{ Mossor } \\
\hline artantal & 883 & 1085 & 1968 & 548 & 606 & 415 & c. 612 \\
\hline bedömda & 856 & 989 & 1062 & $?$ & 450 & 0 & 0 \\
\hline hotade & 136 & 92 & 142 & $?$ & 74 & - & - \\
\hline \multicolumn{8}{|l|}{ Lavar } \\
\hline artantal & 1452 & 2408 & 1976 & 950 & 830 & 470 & c. 950 \\
\hline bedömda & 1450 & 1021 & 1207 & $?$ & 270 & 0 & 0 \\
\hline hotade & 99 & 136 & 168 & $?$ & 67 & - & - \\
\hline \multicolumn{8}{|l|}{ Alger } \\
\hline artantal & $<6000$ & 598 & 755 & $>516$ & 500 & 213 & 2115 \\
\hline bedömda & 111 & 219 & 301 & $?$ & 238 & 0 & 0 \\
\hline hotade & 6 & 20 & 18 & $?$ & 42 & - & - \\
\hline \multicolumn{8}{|l|}{ Svampar } \\
\hline artantal & 4798 & 4800 & 10000 & 3000 & 1880 & 626 & c. 1600 \\
\hline bedömda & 3798 & 4000 & 2402 & $?$ & $?$ & 0 & 0 \\
\hline hotade & 265 & 301 & 324 & $?$ & $?$ & - & - \\
\hline
\end{tabular}

${ }^{1}$ Uppskattat totalt artantal per artgrupp och land

${ }^{2}$ Arter, vars status är bedömd

${ }^{3}$ Bedömda arter, som har konstaterats vara hotade (akut hotade CR, starkt hotade EN ja sårbara VU)

${ }^{4}$ Häckande fåglar

${ }^{5}$ Kärlväxter/apomiktiska

Landsvisa kommentarer:

- Finland: alger - hotbedömningen innefattar endast makroalger, i totala artantalet ingår också mikroalger.

- Sverige: kärlväxter - inga underarter, varieteter etc., andra ryggradslösa - mångfotingar, kräftdjur, tagghudingar,

armfotingar, iglar, planarier, koralldjur. Dessutom finns i Sverige c. 9000 andra obedömda flercelliga arter.

- Norge: alger - endast makroalger, däggdjur - innefattar Svalbards arter, kärlväxter - inga underarter.

- Island: spindeldjur - exklusive kvalster, fiskar - både salt- och sötvattensfiskar, däggdjur - både havs- och landlevande.

- Grönland: däggdjur - också underarter bedömda, fåglar - också regelbundna sommar-/vintergäster bedömda.

IUCN:s hotkategorier:

$\mathrm{CR}=$ akut hotad, $\mathrm{EN}=$ starkt hotad, $\mathrm{VU}=$ sårbar, $\mathrm{NT}=$ missgynnad, $\mathrm{LC}=$ livskraftig, $\mathrm{DD}=$ bristfällig kunskap, NE = inte

bedömd, $\mathrm{RE}=$ försvunnen, $\mathrm{EW}=$ utdöd $\mathrm{i}$ naturen 


\section{Skyddade områdeni Norden}

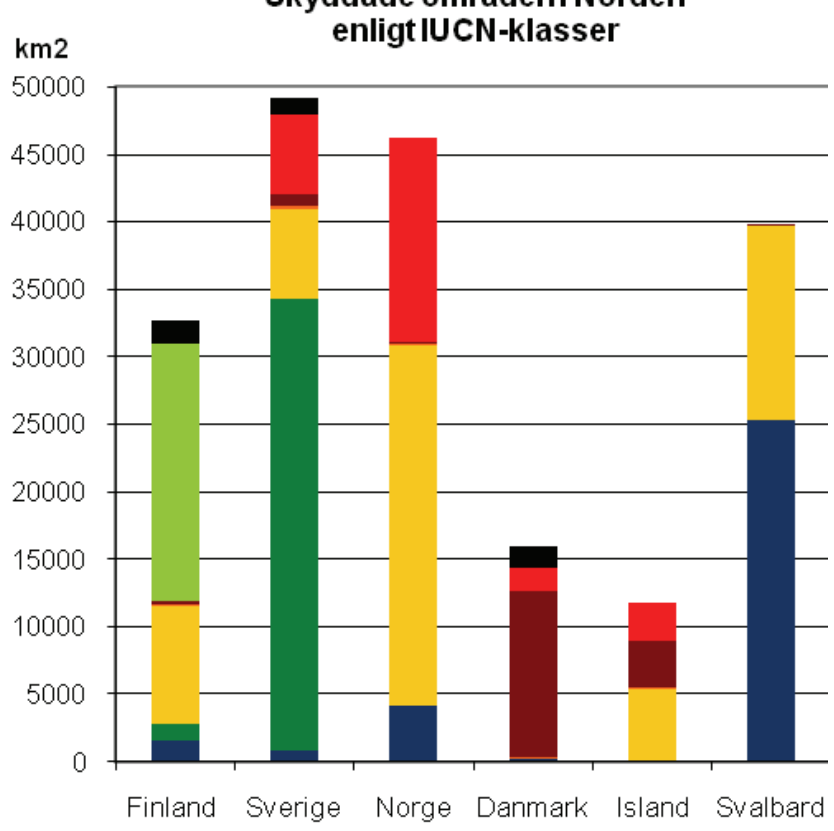

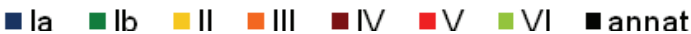

Graf 1: Skyddade områden i Norden

Obs: I Norge (inkl. Svalbard) skiljer man inte på klasserna la och lb. I grafen motsvarar la Norges sammanslagna klass I. I Finland är bara en liten del av alla naturskyddsområden klassificerade enligt IUCN:s klasser och de oklassificerade ingår här i klassen "annat". I Grönland finns c. 982550 km2 naturskyddsområden och de finns inte med i grafen. Grönlands naturskyddsområden är till största delen av klass II.

Källor:

Finlands naturskyddsområdesregister 2006, UN List of Protected areas 2003, Direktoratet for Naturforvaltning 2007, Umhverfisstofnun The Environment Agency of Iceland 2007.

IUCN skyddsområdesklassificering:

la: Strikta naturreservat avsätts i första hand för vetenskaplig forskning.

lb: Ödemarksskyddsområden avsätts i första hand för att bevara områdenas naturtillstånd och ödemarkskaraktär.

II: Nationalparker avsätts för att bevara enastående naturområden av nationell eller internationell betydelse för forskning, utbildning och rekreation.

III: Naturminnesmärken avsätts för att skydda och bevara betydelsefulla, särskilt intressanta eller unika naturfenomen. IV: Naturreservat/Viltreservat. Dessa områden avsätts för att säkra de naturförhållanden som krävs för att skydda nationellt betydelsefulla arter, artgrupper, organismsamhällen eller fysiska karaktärsdrag i miljön.

V: Skyddade landskap (terrestra och marina) är områden som avsätts för att bevara nationellt betydelsefulla naturlandskap som karaktäriseras av en harmonisk balans mellan människan och landskapet.

VI: Förvaltnings- och skyddsområden för naturresurser avsätts för naturresursförvaltning som baserar sig på hållbart bruk av naturliga ekosystem.

Noggrannare definitioner av klasserna finns i publikationen:

IUCN 1994. Guidelines for Protected Area Management Categories. CNPPA with the assistance of WCMC, IUCN, Gland,

Switzerland and Cambridge, UK. [http://www.unep-wcmc.org/protected_areas/categories/index.html] 


\subsection{Källorna till tabellen}

\section{Finland}

Rassi, P., Alanen, A., Kanerva, T. \& Mannerkoski, I. (red.). 2001. Suomen lajien uhanalaisuus 2000 - The 2000 Red List of Finnish species. Ympäristöministeriö \& Suomen ympäristökeskus, Helsinki.

Sverige

Gärdenfors, U. (red.). 2005. Rödlistade arter i Sverige 2005 - The 2005 Redlist of Swedish Species. Artdatabanken, Uppsala.

Norge

Kålås, J.A., Viken, Å. \& Bakken, T. (red.). 2006. Norsk Rødliste 2006 2006 Norwegian Red List, Artsdatabanken, Norge.

Bakken, T. et al. 2005. Utredning for Artsdatabanken, Artsdatabanken, Norge.

Viken, Å. \& Kålås, J.A. 2007: Rødlista og insektene, Insekt-Nytt 32 (1/2) 2007.

Danmark

Stoltze, M. \& Pihl, S. (red.). 1998. Rødliste 1997 over planter og dyr i Danmark. Miljø- og Energiministeriet, Danmarks miljøundersøgelser \& Skov- og Naturstyrelsen.

Prip, C., Wind, P. \& Jørgensen, H. 1995. Biologisk mangfoldighet i Danmark - Status og strategi, Miljø- og Energiministeriet.
Island

Hersteinsson, P. \& Sigbjarnarson, G (red.). 1993. Villt íslensk spendýr. Hið íslenska náttúrufræðifélag, Landvern.

Náttúrufræðistofnun Íslands. 2000. Válisti 2: Fuglar. Reykjavík.

Agnarson, I. 1996. íslenskur köngulær. Fjölrit Náttúrufræðistofnunar 31.

Náttúrufræðistofnun Íslands. 1996. Válisti 1: Plöntur. Reykjavík.

Jón Baldur Sigurðsson. 2008. Náttúrustofa Reykjaness, Island. pers. komm.

Guðmundur A. Guðmundsson. 2008. Náttúrufræðistofnun Íslands. pers. komm.

Karl Gunnarson, Guðriður Gyða Eyjólfsdóttir \& Gunnar Jónsson. 2008. Hafsrannsóknastofnunin, Island. pers. komm.

Erling Ólafsson. 2008. Náttúrufræðistofnun Íslands. pers. komm.

\section{Färöarna}

Fosaa, A.M., Dalsgarð J. \& Gaard E. 2006. Føroya Náttúra- Lívfrøðiligt margfeldi. Føroya Skúlabókagrunnur.

\section{Grönland}

Dorte Bugge Jensen \& Kim Diget Christensen (red.). 2003. The Biodiversity of Greenland - a country study, Technical Report No. 55, Pinngortitalerifik, Grønlands Naturinstitut. 


\section{Nordens natur - trender mot 2010}

Exempel på nordiska bidrag till att nå det internationella 2010-målet för biodiversitet

Det internationella målet att sakta ner, och till och med hejda minskningen av biologisk mångfald före år 2010 ingår också i Nordiska ministerrådets miljöhandlingsprogram för åren 2009-2012. Det är redan nu klart att målet inte nås, trots att otaliga både stora och små insatser, som har främjat bevarandet och skyddet av den biologiska mångfalden har gjorts i de nordiska länderna. Under märkesåret 2010 firas FN:s internationella biodiversitetsår. Under året formuleras nya mål, och biologiska mångfaldens betydelse för naturen och människan lyfts fram. Arbetet för den biologiska mångfalden fortsätter - också efter år 2010.

Projektet Nordens natur - trender mot 2010 presenterade nordiska exempel på succéer inom biodiversistesskyddet, samt hot mot bevarandet av biologiska mångfalden, och skyddsåtgärder, som inte har gett önskat resultat. Exemplen publicerades som elektroniska faktablad på projektets webbplatser på alla nordiska språk och på engelska. Faktabladen, samt en sammanfattning om biologiska mångfaldens utveckling och tillstånd i Norden har samlats i denna publikation, som utgör en del av Nordens bidrag till att nå 2010-målet och att öka kunskapen om den biologiska mångfaldens betydelse. 